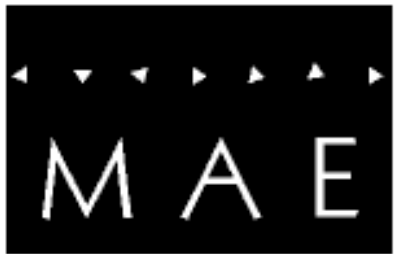

UNIVERSIDADE DE SÃO PAULO

MUSEU DE ARQUEOLOGIA E ETNOLOGIA

Av. Prof. Almeida Prado, 1466-Cidade Universitária-São Paulo-CEP 05508-900

\author{
UNIVERSIDADE DE SÃO PAULO \\ MUSEU DE ARQUEOLOGIA E ETNOLOGIA \\ PROGRAMA DE PÓS-GRADUAÇÃO EM ARQUEOLOGIA
}

\title{
Práticas Arqueológicas e Alteridades Indígenas
}

\author{
Frederic M. C. Pouget
}

Dissertação apresentada ao Programa de Pós-Graduação em Arqueologia do Museu de Arqueologia e Etnologia da Universidade de São Paulo para obtenção do título de Mestre em Arqueologia.

Orientador: Prof ${ }^{a}$. Dra . Fabiola Andréa Silva.

Linha de Pesquisa:História da Arqueologia e Perspectivas Teóricas Contemporâneas.

São Paulo

2010 


\section{Agradecimentos}

Ao Programa de Pós-Graduação em Arqueologia da Universidade da São Paulo (USP). Aos funcionários do Museu de Arqueologia e Etnologia (MAE) e a sua excelente biblioteca.

À FAPESP pela bolsa concedida desde o inicio desta pesquisa. À Rede Macro Universidade da América Latina e Caribe, pelo financiamento do estágio na Universidad de Buenos Aires. A Dra Mônica Beron e colegas de campo e estágio do Museo Etnográfico Juan Bautista Ambrosetti em Buenos Aires.

Ao Núcleo de Historia Indígena e Indigianismo (NHII) da USP e seus integrantes, pelo estimulante debate e intercambio de idéias de suas reuniões e seminários. As professoras do departamento de antropologia Dominique Gallois, Beatriz Perrone Moisés e Marta Amoroso, pelo intercâmbio e incentivo desta pesquisa. Ao Instituto Sócio Ambiental e a Ciça pelo acesso a sua base de dados.

À Prfa Dra Fabiola Andrea Silva cuja "cultura arqueológica" é admirável pela consistência e abrangência de assuntos, por ter aceitado me orientar tanto nesta pesquisa quanto no estágio anterior no Laboratório de Etnoarqueologia.

Aos colegas de campo e de curso Francisco Forte Stuchi e Eduardo Bespalez, cuja inserção e diálogo para com as comunidades indígenas foram essenciais na elaboração desta dissertação. Às comunidades da Aldeia Lalima e Terra Indígena Kaiabi que, infelizmente, ainda sofrem com as conseqüências da política colonialista do Estado Brasileiro. Eles nos mostraram uma pequena parte da sua riqueza imaterial, nos receberam e apoiaram a nossa pesquisa, são os verdadeiros co-autores desta dissertação.

Aos demais colegas do programa de pós-graduação. Aos professores e arqueólogos do MAE que possibilitaram participação em campanhas arqueológicas: Levy Figuti, Paulo DeBlasis, Denis e Agda Vialou. Ao arqueólogo Fabiano Lopes.

Aos professores Renato Stutzman e Pedro Paulo A. Funari pela leitura atenta, críticas e sugestões, que possibilitaram um impagável crescimento acadêmico. Aos amigos de graduação companheiros da vida acadêmica e da vida em geral: Bruno, Bruna, Lê, Danilo, Déia, Dea, Ana Bi, Oli, Jú , Carol, Gustavo e André. A minha Família pelo amor e apoio sentimental (e material): Ramiro, Ivone, Tia Ni, Tio Fernando, Karina, Chico, Tales. E a sempre companheira Origami. 


\section{RESUMO}

\section{Práticas arqueológicas e alteridades indígenas}

O que proponho nesta pesquisa é explorar as redes de relações (institucionais, políticas ou 'naturais') ou, em outras palavras, a sociabilidade em si, decorrente da prática do arqueólogo em território indígena e colocar em contraste o debate antropológico sobre a alteridade. É necessário ressaltar que não se trata de criticar as redes sociais ou refletir através da sociologia crítica o embate entre grupos sociais, mas de explorar as tensões existentes no aspecto abstrato, no mundo conceitual que formula a alteridade tanto do cientista quanto da comunidade indígena, configurando-se, assim, em um exercício de análise simétrica.

Palavras-chave: teoria arqueológica; arqueologia simétrica etnoarqueologia; kaiabi ; terena

\section{Abstract}

\section{Archaeological Practices and Indigenous Alterities.}

My intention in this research is to explore the networks of relations (institutional, politics or "naturals") or, in other words, the sociability itself; as a consequence of the archeological practice in an indigenous territory; also, to contrast the anthropological debate regarding alterity. It is necessary to highlight that this work do not aim to criticize social networks or to reflect through critical sociology the tensions between social groups, but to explore the existing strains in the abstract arena, in the conceptual world that shows the alterity of the researches and also of the indigenous community, conforming a symmetrical analysis exercise.

Key words: theory in archaeology; symmetrical archaeology; ethnoarqueology; Kaiabi; Terena. 
“O problema político essencial para o intelectual não é criticar os conteúdos ideológicos que estariam ligados à ciência ou fazer com que sua prática científica seja acompanhada por uma ideologia justa; mas saber se é possível constituir uma nova política da verdade. O problema não é mudar a "consciência" das pessoas, ou o que elas têm na cabeça, mas o regime político, econômico, institucional de produção da verdade.".

(Michel Foucault, Microfisica do Poder, p.14)

"Se existe uma coisa que todos fazemos da mesma forma é construir ao mesmo tempo nossos coletivos humanos e os não-humanos que os cercam. Alguns mobilizam, para construir seu coletivo, ancestrais, leões, estrelas fixas e o sangue coagulado dos sacrifícios; para construir os nossos, nós mobilizamos a genética, a zoologia, a cosmologia e a hematologia." (Bruno Latour, Jamais Fomo Modernos, 1994:104) 
Índice

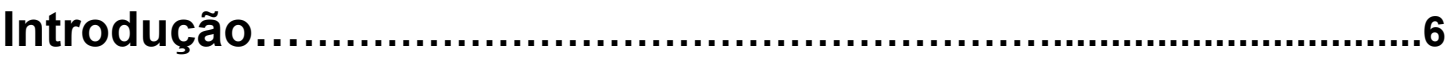

\section{Capitulo 1.}

Aspectos teóricos e metodológicos

1.1 Etnografia entre arqueólogos, etnografia da ciência.

O cenário internacional sobre etnografias da prática arqueológica..........11

1.2 Questões teóricas e metodológicas da pesquisa...................................16

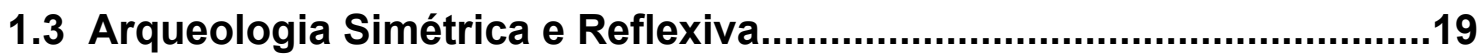

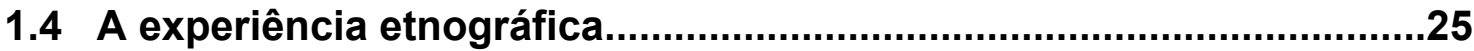

\section{CAPITULO 2.}

A experiência etnográfica na Aldeia Lalima.

\section{CAPITULO3.}

A experiência etnográfica na Terra Indígena Kaiabi. .61

\section{Capitulo 4.}

(In)visibilidade das perspectivas territoriais e patrimoniais: percepção indígena e discursividades políticas e científicas.

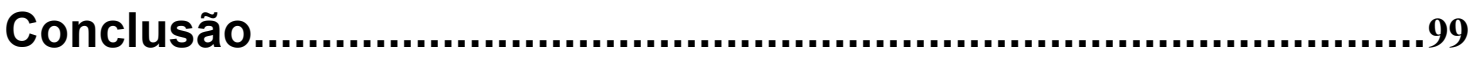

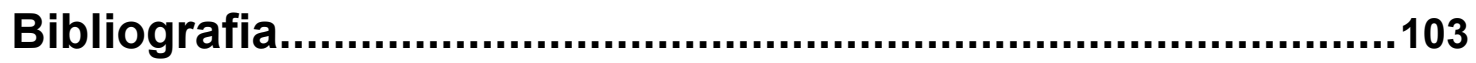
ANEXOS
Anexo1 Dialogo entre cientistas.
Anexo 2 Dialogo com o Cacique Terena.............................................118
Anexo3 Conflito com a Vizinha, Aldeia Lalima....................................119
Anexo4 Entrevista com Ancião1 e Ancião2, Aldeia Lalima ...............120
Anexo5 Moção de encaminhamento do I SEMINÁRIO INTERNACIONAL DE GESTÃO DO PATRIMÔNIO ARQUEOLÓGICO PAN-AMAZÔNICO....126 


\section{Introdução}

\section{Cruzamento de focos}

O cerne da Arqueologia é sua interdisciplinaridade. Assim, é essencial deixar abertas as possibilidades teóricas trazidas por outras disciplinas. Foi sempre no trato de novas abordagens que a arqueologia se desenvolveu enquanto ciência e contribuiu teórica e tecnicamente com outras disciplinas e vice-versa. Então, em áreas como a etnoarqueologia, a relação é mais forte ainda, justamente por ser esta uma área de contato interdisciplinar que permite analisar o movimento dialético entre arqueologia e antropologia. A pesquisa sobre novos paradigmas da antropologia possibilita novas reflexões e questões, inclusive sobre a prática do arqueólogo em campo, já que a figura do outro, o índio, exige uma reflexão profunda sobre alteridade, não apenas pela questão territorial, mas também pelo discurso da indigenização, ou seja, a afirmação político-identitária perante o branco ou, no sentido inverso, na projeção de categorias sociais e científicas do observador sobre o observado. Ou seja, a prática da arqueologia traz em si um discurso próprio de alteridade, sua autoimagem de ciência, que pode entrar em conflito com a construção de alteridade indígena. Disso decorrem as seguintes questões: quais tensões, se é que elas existem, marcam o trabalho de campo arqueológico em território indígena? Pode, dessa maneira, a vertente teórica da antropologia reflexiva contribuir para a análise e interpretação arqueológica, principalmente, no que se refere à problematização da alteridade? Existe uma tensão entre empirismo e a interdisciplinaridade teórica na arqueologia?

O discurso de etnicidade na etnoarqueologia possui uma importância cada vez maior no que se refere às intersecções de processos culturais de indentidadealteridades. Segundo Siân Jones (1997), no meio acadêmico todas as questões sobre etnicidade, multiculturalismo e nacionalismo eram vistas por um viés político depreciativo e, portanto, segundo a ótica processual, seriam desqualificadas 
cientificamente, já que ciência era (e é ainda, para alguns) encarada como neutra politicamente. A arqueologia pós-processual recupera esse aspecto sociopolitico e o problematiza, explorando a natureza da arqueologia como prática contemporânea, envolvida na construção da identidade cultural. Nesse sentido, contribuições teóricas importantes a respeito da prática arqueológica e das alteridades indígenas foram feitas por autores como Robert Layton (1994a,1994b), Bond e Gilliam (1994), Watkins (2000), Torrence e Clark (2000), Smith e Wobst (2005), Thomas e Colley (2005), Funari, Zarankin e Stovel (2005), mostrando que o interesse pelo passado e o acesso a este é mais amplo do que os círculos acadêmicos. São as comunidades locais, onde vestígios arqueológicos remetem a sua ancestralidade, que se interessam cada vez mais pelo conhecimento arqueológico, não só para uma interpretação própria de seu passado, mas também como instrumento político. Esse momento teórico leva em consideração categorias nativas de reflexão sobre o passado e a necessidade de contrapor esse conhecimento ao conhecimento arqueológico tradicional. Do mesmo modo, coloca-se a questão política do controle dos processos de escavação, dos sítios arqueológicos em área indígena e até mesmo do destino e controle dos artefatos encontrados. Tudo isto relacionado a questões de territorialidade, patrimônio, fluxo comercial e turístico e a questão sociológica clássica do "conhecimento para quem?". Novamente, o que se impõe é a discussão de categorias de análises etnocêntricas e o uso destas, que podem criar vieses na interpretação arqueológica como nos lembra lan Hodder (1982a, 1982b, 1985, 1997).

Dado esse contexto teórico de produções científicas, a dissertação pretendida pode parecer, à primeira vista, caminhar nesta linha pós-processual, de questionamentos sociopolíticos e sobre categorias nativas, ou mesmo para uma reflexão sobre o panorama teórico ou sociopolítico da etnoarqueologia (trabalho este realizado por Rita Juliana Poloni, 2007). No entanto, como veremos mais adiante (capitulo 1), existiria um princípio ontológico que orienta e ao mesmo tempo enclausura tanto as pesquisas processuais quanto as pós-processuais. $A$ elaboração da noção de antropologia reflexiva e simétrica nas obras de Bruno Latour (1994; 2000; 2005), Roy Wagner (1981) e Marily Strathern (1987; 1988; 1992) possibilita a consideração desse princípio e a possibilidade de um passo adiante no desenvolvimento da disciplina científica. Para isso é necessário 
retomar a noção de agência em arqueologia e acompanhar o seu papel para uma abordagem reflexiva da arqueologia. Essa pesquisa segue esse desenvolvimento teórico não só no questionamento sobre agência - em uma visão particular de etnografia da prática arqueológica -, mas também no intuito de pensar a própria pesquisa enquanto rede, que na visão latouriana significaria pensar a rede como metáfora para uma perspectiva teórico-metodológica de trabalho (LATOUR 2005).

Portanto, as etnografias apresentada neste trabalho são o início de uma rede que possibilita a articulação reflexiva com diversos âmbitos teóricos da arqueologia, tais como: território, patrimônio, poder, agência, tradição oral, percepção etnoarqueológica, percepção temporal, cosmogonia indígena, multivocalidade, identidade e alteridade.

\section{O desenvolvimento do projeto de pesquisa}

Este projeto se insere no campo da etnoarqueologia, abordando mais especificamente a arqueologia feita em território indígena. Com este pano de fundo, a dissertação apresentada é uma reflexão sobre a prática arqueológica contemporânea em território indígena no Brasil, levando em conta o acúmulo de debate na antropologia e arqueologia sobre a alteridade, que pode trazer boas reflexões para esta prática arqueológica.

Em especial, é o método analítico da antropologia reflexiva que ajudará a observar a prática do cientista junto a formulações conceituais indígenas e assim estabelecer uma base de comparação. É em uma etnografia feita entre cientistas, entre arqueólogos, que as suas práticas e seus pressupostos podem ser verificados, além de demonstrar possíveis tensões decorrentes da visão indígena sobre essa prática. Tal articulação teórico-metodológica pode ser verificada mais detalhadamente no Capítulo 1.

O projeto teve como objetivo a observação em primeira mão do ofício do arqueólogo, da produção de conhecimento que utiliza os pesquisadores e os índios como interlocutores, assim como compreender os processos envolvidos na construção do fato científico, apreender seu repertório léxico e de práticas, a língua dos cientistas. Para isso a participação efetiva foi essencial, ou seja, foi necessário aprender a segurar a colher de pedreiro! Participar de fato de 
escavações arqueológicas enriqueceu tanto a minha formação como arqueólogo como a captura de dados para a pesquisa. Mas, ao mesmo tempo, foi preciso manter o olhar distanciado, próprio das análises antropológicas. Portanto é na sua práxis - por isso a necessidade da observação participante - que as subjetividades implícitas da teoria se revelam.

O campo consistiu na observação da atividade arqueológica na construção do fato científico, como, por exemplo, os processos de seleção de evidências arqueológicas e de categorização e classificação do registro arqueológico, o que implica a reflexão sobre a formação de quadros tipológicos e conseqüências não previstas da ação do arqueólogo em campo, principalmente no que diz respeito a trabalhos científicos sobre comunidades indígenas. Já que a identidade material (como, por exemplo, aspectos de antigüidade) não é uma propriedade intrínseca ao objeto, ela é decorrente da relação entre as pessoas e o objeto.

Os campos etnográficos foram realizados no decorrer da construção do projeto de Auxílio Pesquisa Fapesp "Arqueologia, etnoarqueologia e história indígena - um estudo sobre a trajetória da ocupação indígena em territórios do Mato Grosso e do Mato Grosso do Sul: a terra indígena Kaiabi e a aldeia Lalima" (processo $\mathrm{n}^{\circ}$ 06/60241-8), coordenado pela Profa ${ }^{\mathrm{a}} \mathrm{r}^{\mathrm{a}}$ Fabíola Andréa Silva (SILVA et al. 2007), do Museu de Arqueologia e Etnoarqueologia da Universidade de São Paulo, o que possibilitou minha inserção numa equipe de arqueologia e o acompanhamento da atuação desta em território indígena. A passagem seguinte ilustra a proposta desse projeto.

"No Brasil, vários autores têm conduzido suas pesquisas arqueológicas no sentido de contribuir para o entendimento das trajetóras históricas e dos processos de continuidade e mudança cultural vividos pelas populações indígenas arqueológicas, históricas e atuais (p.ex Brochado 1984; Eremites Oliveira 1996; Heckenberger 2005; Neves 1998 e 1999; Noelli 1993 e 1999; Wüst 1993). A nossa pesquisa tem este mesmo objetivo, visando contribuir no entendimento das trajetórias históricas e culturais das diferentes populações que ocuparam e ocupam os territórios onde hoje estão a Aldeia

Lalima/MS e a T.I. Kaiabi/MT. Esta proposta de pesquisa foi concebida a partir do pressuposto de que a Arqueologia pode contribuir para o entendimento da "história de longa duração" de diferentes populações (Hodder 1996:1-8; 2003:125155).

(...)

Desejamos contribuir para a recuperação destas histórias e os dados arqueológicos, históricos e etnográficos já existentes sobre os estados do Mato Grosso e Mato Grosso do Sul indicam que os mesmos foram ocupados, desde o passado, por povos indígenas bastante diversos culturalmente. Cabe ressaltar, porém, que não se pretende usar estes dados para construir uma história essencialista destas etnicidades, pois nós conhecemos e concordamos com as 
críticas que foram feitas a este tipo de construção interpretativa do passado (Jones 1996). O que queremos é tentar vislumbrar os processos de continuidades, mudanças e rupturas nas trajetórias destas populações e a dialética entre passado e presente, para isso considerando as interpretações indígenas sobre este

processo histórico e cultural como vem sendo feito em outros contextos (p.ex. Layton 1985, 1989; Eluyemi 1994; Sutton 2005; Endere 2005).

(...)

Assim, o arqueólogo pode, teoricamente, reconstruir a história de vida de um território partir da detecção dos correlatos materiais das atividades associadas aos processos contidos nas trajetórias de formação dos territórios. Obviamente, cada território apresenta uma trajetória histórica própria de formação, todavia, acreditamos que os princípios do modelo de história de formação territorial são suficientemente coerentes enquanto ponto de partida para o estudo das trajetórias específicas da Aldeia Lalima e da T.I. Kaiabi. Cabe ressaltar que tentar entender atrajetória histórica de formação dos territórios torna-se crucial em contextos de pesquisa arqueológica em territórios indígenas, pois éeste conhecimento que, muitas vezes, torna-se "o fundamento dos direitos territoriais indígenas e, particularmente, de garantia de suas terras" (Carneiro da Cunha 1998: 20)."

A análise mais detalhada das duas experiências etnográficas - a Aldeia Lalima e T.I. Kaiabi - podem ser acompanhadas nos Capítulos 2 e 3.

Um outro ponto da observação em campo foi estabelecer um olhar atento sobre o contexto social da pesquisa, de como é realizada, sob quais condições ela é feita e quais agências são mobilizadas. Se em um estudo etnográfico clássico o campo consiste em um território específico, a etnografia de uma ciência procura as redes de mediações sociotécnicas, para além desse território determinado. Portanto, foi necessário no decorrer da pesquisa explorar as redes discursivas que articulavam e influenciavam a nossa inserção em campo, mais especificamente os contextos políticos nos quais se desdobravam as noções de patrimônio e território. Tal abordagem pode ser verificada no Capítulo 4.

Por fim, na parte final deste trabalho, se encontram os principais pontos levantados na pesquisa e a reflexão final decorrente das pesquisas etnográficas. 


\section{Capitulo 1.}

\section{Aspectos teóricos e metodológicos}

\subsection{Etnografia entre arqueólogos, etnografia da ciência. O cenário internacional sobre etnografias da prática arqueológica}

Apesar desse tipo de abordagem parecer original, a perspectiva etnográfica da prática arqueológica começa a ser configurada cerca de cinqüenta anos atrás, em um sintético artigo de um antropólogo norte-americano chamado Louis Dupree (1955). Ele sugere que é possível abordar um grupo de trabalho arqueológico como objeto sociológico, já que um pequeno grupo social é formado, "artificialmente", pelo contexto de trabalho do arqueólogo. Esse grupo, composto por trabalhadores contratados, auxiliares técnicos e, inclusive, pelo arqueólogo, passa de um caráter artificial de sociabilidade imposta para uma interação 'natural', no sentido de um trabalho em conjunto e uma sociabilidade compartilhada no estabelecimento de regras construídas ao longo do trabalho de campo. No entanto, o grupo permanece temporário, já que se desfaz assim que a escavação arqueológica termina. Uma outra observação de Dupree diz respeito ao papel duplo do arqueólogo como técnico e cientista social. Assim, o autor propõe, apesar de não ter levado a cabo, o estudo comparativo sobre a interatividade da prática arqueológica em diferentes contextos de pesquisa. A sugestão de Dupree, de que os arqueólogos possam ter um papel de observadores antropológicos e que as equipes de escavação possam ser constituídas como objeto de observação etnográfica, coloca em foco um importante problema metodológico de caráter reflexivo, que é pensar criticamente a própria prática científica para além de embates teóricos. Pensar a práxis em si é que leva a uma configuração de uma determinada ciência.

Desde o trabalho pioneiro de Dupree, três linhas de pesquisa foram se delineando, tendo em vista o aspecto etnográfico da prática arqueológica: etnografia arqueológica, etnografia (antropologia) da arqueologia e arqueologia etnográfica. Castañeda (2008) nos oferece um quadro sistemático onde essas abordagens podem ser comparadas e diferenciadas através de quatro eixos temáticos. O primeiro eixo se refere à agenda básica de pesquisa; o segundo é 
referente à especificação do objeto de estudo; o terceiro é o papel desempenhado pela etnografia e a sua relação com a arqueologia; e por fim, o quarto eixo é o propósito da pesquisa.

\begin{tabular}{|c|c|c|c|}
\hline $\begin{array}{l}\text { Linha/Eixo } \\
\text { Caracterização }\end{array}$ & $\begin{array}{l}\text { "Etnografia Arqueológica" } \\
\text { Etnografia como método da } \\
\text { arqueologia }\end{array}$ & $\begin{array}{l}\text { "Antropologia da Arqueologia" } \\
\text { Arqueologia como objeto da } \\
\text { etnografia }\end{array}$ & $\begin{array}{l}\text { "Arqueologia Etnográfica" } \\
\text { Arqueologia como sujeito da } \\
\text { etnografia (sujeito etnográfico) }\end{array}$ \\
\hline 1. Agenda & $\begin{array}{llr}\text { Estudar } & \text { o } & \text { "passado" } \\
\text { arqueológico e/ou os padrões } \\
\text { da cultura } & \text { material na } \\
\text { formação } & \text { do } & \text { registro } \\
\text { arqueológico. } & & \end{array}$ & $\begin{array}{l}\text { Estudar a arqueologia como } \\
\text { fenômeno contemporâneo } \\
\text { (sociocultural e político) que } \\
\text { atua no mundo presente. }\end{array}$ & $\begin{array}{l}\text { Estudar a arqueologia em seu } \\
\text { contexto sociológico, sua } \\
\text { agência e seus processos de } \\
\text { engajamento com o mundo. }\end{array}$ \\
\hline $\begin{array}{l}\text { 2. Objeto de } \\
\text { estudo }\end{array}$ & "o passado" & "Arqueologia" & $\begin{array}{l}\text { "o posicionamento da } \\
\text { pesquisa" em projetos de } \\
\text { arqueologia (contextos sócio- } \\
\text { políticos da arqueologia; } \\
\text { dinâmicas de pesquisa; } \\
\text { interação com as comunidades } \\
\text { como partes envolvidas na } \\
\text { pesquisa } \\
\text { significados e reclamações em } \\
\text { relação ao "passado" } \\
\text { manifestados } \\
\text { comunidades envolvidas. }\end{array}$ \\
\hline $\begin{array}{l}\text { 3. Papel da } \\
\text { Etnografia "Role" }\end{array}$ & $\begin{array}{l}\text { Metodologias etnográficas } \\
\text { usadas na arqueologia como } \\
\text { uma ferramenta cientifica para } \\
\text { investigar facetas específicas } \\
\text { do passado (ou do presente) e } \\
\text { da cultura material no } \\
\text { entendimento do passado. }\end{array}$ & $\begin{array}{l}\text { Métodos etnográficos são } \\
\text { usados para investigar a } \\
\text { arqueologia em relação com } \\
\text { outras forças sociais } \\
\text { contemporâneas, atores, } \\
\text { processos e dinâmicas no } \\
\text { mundo; sem relação } \\
\text { necessária com a arqueologia. }\end{array}$ & $\begin{array}{l}\text { Métodos etnográficos são } \\
\text { incorporados no fazer da } \\
\text { pesquisa arqueológica, com o } \\
\text { intuito de elucidar tanto o } \\
\text { passado arqueológico quanto } \\
\text { contextos sociais no presente, } \\
\text { dinâmicas e processos da } \\
\text { arqueologia. }\end{array}$ \\
\hline $\begin{array}{l}\text { Relação de... } \\
\text { 4. Propósito }\end{array}$ & $\begin{array}{l}\text { "Subordinação" } \\
\text { Criar entendimento do } \\
\text { passado arqueológico (ou do } \\
\text { passado em geral) através, } \\
\text { primariamente, da cultura } \\
\text { material. } \\
\text { “...arqueologia como um } \\
\text { campo de estudo do passado } \\
\text { e/ou como ciência do } \\
\text { passado." }\end{array}$ & $\begin{array}{l}\text { "Externo" } \\
\text { Criar entendimento entre os } \\
\text { campos do poder e público, } \\
\text { nos quais a antropologia é } \\
\text { praticada e compreender seus } \\
\text { efeitos. } \\
\text { “... etnografia como disciplina } \\
\text { diferenciada preocupada com } \\
\text { processos contemporâneos". }\end{array}$ & $\begin{array}{l}\text { "Integração" } \\
\text { Criar modos de engajamento } \\
\text { entre as partes interessadas e } \\
\text { negociar os sentidos do } \\
\text { passado via entendimentos } \\
\text { dos processos de pesquisa e } \\
\text { de sua dinâmica. } \\
\text { "... arqueologia como ética e } \\
\text { eticamente engajada no } \\
\text { empreendimento cientifico" }\end{array}$ \\
\hline
\end{tabular}


Portanto, como posto por Castañeda (2008), a linha "Etnografia Arqueológica"se refere diretamente ao conceito de Etnoarqueologia como é comumente usado nos trabalhos de arqueologia em território indígena no Brasil. No entanto, é necessária uma melhor qualificação das diversidades de abordagens teóricas e metodológicas que a prática etnoarqueológica sugere tanto em perspectivas processuais quanto pós-processuais. (vide sub-item 1.2)

O segundo eixo, "antropologia da arqueologia", pode ser verificado em uma diversidade de trabalhos em estudos pós-processualistas marcados por um caráter reflexivo. A perspectiva etnográfica reflexiva foi levada a cabo em uma escavação, em 1967, quando Ove Wall, Anita Christianson e Helena Wall realizaram um estudo sociométrico sobre cooperação em um trabalho de campo arqueológico na Suécia (EDGEWORTH, 2006). Nesse caso, a problemática sobre reflexibilidade não chegou a se configurar já que o trabalho de observação foi realizado por outros, permitindo, inclusive, que o coordenador de campo fosse incluso como objeto de observação. Os temas abordados durante o estudo foram as influências de diferentes backgrounds educacionais dos pesquisadores na cooperação intragrupo e as relações entre o coordenador-chefe e sua equipe, assim como a interação entre diferentes grupos de pesquisa que trabalhavam no sítio.

Durante o predomínio da Nova Arqueologia no cenário internacional, durante a década de 1970 e início dos anos 1980, a ênfase na objetividade científica desencorajou a continuação dessa abordagem etnográfica da ciência arqueológica, com exceção de alguns trabalhos como o de Mary Sellar e Kent Flannery's sobre a comunidade arqueológica. (EDGEWORTH, 2006). A volta da idéia de uma etnografia da arqueologia aparece ao mesmo tempo de formas diferentes, em diferentes lugares do mundo: nos trabalhos de Edgeworth (1991), por exemplo, que fez uma etnografia de uma escavação de um cemitério da Idade do Bronze no leste da Inglaterra. Nessa pesquisa, ele observa a construção do dado arqueológico não somente no registro empírico, mas na própria cotidianidade da escavação, nos "atos de descoberta". Aparece também nos trabalhos de Blythe Roverland, em 1991-1992, que é, ao mesmo tempo, coordenadora de campo e etnógrafa em uma escavação paleolítica em Piennworthmoor, Alemanha. Podemos citar, também, o trabalho da arqueóloga 
feminista Joan Gero e do antropólogo lingüista Charles Goodwin que, em 1992, realizaram etnografia de uma pesquisa arqueológica na Argentina, no sítio Arroyo Seco 2, escavado por Gustavo Politis. O trabalho de Gero é bem conhecido e citado nas discussões pós-processuais sobre gênero na arqueologia. Já a pesquisa feita por Goodwin é focada na analise lingüística sobre a formação de termos comuns na sociabilidade cultural como, por exemplo, aqueles termos presentes nos discursos sobre a transmissão do métie de um arqueólogo experiente para um novato (EDGEWORTH, 2006).

No Brasil, a primeira iniciativa no eixo da antropologia da arqueologia pode ser vista no artigo Arqueólogos e populações ribeirinhas: uma etnografia do trabalho de campo, de 1988, elaborado por um grupo de técnicos e pesquisadores em arqueologia vinculados ao Museu Paranaense Emilio Goeldi ${ }^{1}$. O sintético artigo procura identificar os agentes sociais envolvidos em uma escavação e as problemáticas decorrentes da interação desses agentes. Tal trabalho foi uma iniciativa louvável no cenário acadêmico brasileiro, porém, não encontramos outros trabalhos com proposta etnográfica similar, com exceção daqueles que tratam de arqueologia pública (BEZERRA DE ALMEIDA, 2003; SCHANN, 2006, 2007; GREEN et al, 2003; FERNANDES, 2008). Ainda na linha da antropologia da arqueologia no Brasil podemos lembrar o trabalho desenvolvido, sob a ótica da arqueologia pública, por Lesley Fordred Green, David R. Green e Eduardo Góes Neves (2003), “Indigenous Knowledge and Archaeological Science: The Challenges of Public Archaeology in the Reserva Uaçá, que traz os Palikur para a reflexão arqueológica, forçando a qualificação de aspectos éticos, epistemológicos e práticos.

A arqueologia etnográfica, tal qual proposta por Castañeda (2008), é concebida não como o uso de um método subordinado aos objetivos da interpretação arqueológica sobre o passado, mas como uma integração profunda do processo etnográfico com o fazer arqueológico. Essa integração altera o caráter da arqueologia, tanto esta deixa de ser objeto de estudo etnográfico (antropologia da arqueologia) quanto a antropologia passa de um instrumento de pesquisa etnoarqueológico para qualificar a relação da arqueologia com as partes

\footnotetext{
${ }^{1}$ OLIVEIRA, Aldeides; MACHADO, Chistiane; MAGALHÂES, Cíntia; ALVARO, Maria Ângela; BARRETO, Mauro; MELLO, Paulo e MURRIETA, Rui. Arqueólogos e populações ribeirinhas: uma
} 
envolvidas no processo de construção do conhecimento arqueológico. Portanto, a arqueologia passa a ser o sujeito etnográfico. Isso significa que o projeto arqueológico é o agente dos processos evolvidos em campo e responde, de forma reflexiva, às atividades desenvolvidas, à interação com outros atores sociais ou instituições e aos contextos sócio-políticos.

Tal proposta pode ser verificada em alguns trabalhos mundo afora. Zimmerman $(2008)^{2}$ chama atenção para o trabalho de Claire Smith (Smith \& Jackson, 2005) junto à comunidade aborígine de Barunga-Wugularr, no norte australiano. A pesquisa consiste na análise da relação entre produção artística e contextos sociais e materiais. As escavações em sítios de arte rupestre foram feitas sob as regras e supervisão de anciãos nativos. Isso se reflete no completo envolvimento dos pesquisadores junto à dinâmica de parentesco da comunidade e na participação desta em publicações científicas e congressos. Os relatórios de pesquisa passam pelo crivo da comunidade e as publicações são feitas em inglês e na língua local. Michel Heckenberger (2008) apresenta uma iniciativa semelhante no Brasil junto aos Kuikuro do Alto Xingu. O trabalho de longa data, aproximadamente15 anos, desenvolvido por ele reflete a incorporação sistemática de pressupostos etnográficos e êmicos na prática contemporânea de arqueologia.

Ou seja, a pesquisa etnoarqueologica desenvolvida por Heckenberger é imbuída por uma perspectiva dialógica cada vez mais presente, que acaba por refletir em uma pesquisa colaborativa. As relações sociais estabelecidas e a confiança mútua desenvolvida qualificam o seu trabalho tanto na perspectiva da comunidade local, quanto das publicações científicas com processos de coautoria pelos Kuikuro.

Apesar de mostrar os pontos de convergência das múltiplas abordagens teóricas da arqueologia recente, Castañeda (2008) não aprofunda a reflexão sobre as transformações que conceitos chaves na arqueologia sofreram no

etnografia do trabalho de campo. In Cadernos do Centro de Filosofia e Ciências Humanas, Belém (15) 37 60. 1988.

2 Zimmerman, faz a sua analise Através da conceitualização da "ethnocritical archaeology", que segundo Castañeda \& Matthews (2008) se aproxima, em termos conceptuais, da arqueologia etnográfica. 
decorrer da disciplina, em especial ao que se refere à Etnoarqueologia ${ }^{3}$ e à Arqueologia Pública ${ }^{4}$.

\subsection{Questões teóricas e metodológicas da pesquisa}

Os diversos âmbitos teóricos da arqueologia, constantemente interligados na experiência etnográfica, fazem com que a pesquisa trabalhe com o cruzamento de focos analíticos. O primeiro é aquele referente à Etnoarqueologia do trabalho arqueológico em área indígena, que pode ser assim definido:

"Em termos amplos, a Etnoarqueologia pode ser entendida como uma abordagem que, a partir do estudo de sociedades contemporâneas, proporciona os meios para formular e testar hipóteses, modelos e teorizações que possibilitam responder questões de interesse arqueológico." (SILVA, 2000:30)

\section{E assim entender a Etnoarqueologia}

“(...) não como analogia, mas como uma estratégia de pesquisa que visa produzir uma base de dados etnográficos sobre as relações entre o comportamento humano e o mundo material, que possa auxiliar nas teorizações sobre os processos de formação dos registros arqueológicos e, ao mesmo tempo, que venha a contribuir para os estudos de cultura material." (SILVA, 2000:46)

No entanto, a perspectiva etnoarqueológica considerada para esta pesquisa é centrada nos aspectos contextualistas (ou pós-processualistas) da etnoarqueologia contemporânea, como bem aponta Gustavo Politis (2002:66)

\footnotetext{
${ }^{3}$ Tal enfoque pode ser encontrado nos textos de Nicholas David (1992) e Nicholas David \& Carol Kramer (2002) referentes à Etnoarqueologia.

${ }^{4}$ Fernandes (2007) sobre o desenvolvimento da Arqueologia Pública nos fornece a seguinte reflexão:

“A década de 1980 representou o início de uma avaliação crítica da comunidade arqueológica sobre o papel da disciplina no Brasil perante à sociedade, demonstrado nos fóruns de debates promovidos pela sociedade de arqueologia brasileira, nos artigos discutindo Arqueologia e Educação - a representação da arqueologia para o público; bem como o envolvimento nas questões sobre gestão de recursos ambientais e culturais. Deste modo pode-se afirmar, corroborando com Barreto (1999-2000) e Souza (1991), que a disciplina nessa década abres-se e busca formas de diálogo interno e externo sobre as questões públicas da Arqueologia envolvidas na teoria, mas principalmente na prática arqueológica. Esta preocupação da comunidade prossegue na década seguinte com outras avaliações críticas sobre o papel do arqueólogo, sua responsabilidade social e científica. Este ambiente favorável vai possibilitar no final da década de 1990 e início do século XXI o desenvolvimento da Arqueologia Pública no Brasil, influenciada pelos debates da comunidade arqueológica internacional sobretudo a norte-americana.(FERNANDEZ, 2007:60)
} 


\section{"Etnoarqueologia passa a interessar-se não só pelo processo de produção}

artefactual, mas também pelas redes de significados que o envolve”.

Sobre a relação da etnoarqueologia com a vertente teórica do pós-

processualismo, Nicholas David \& Carol Kramer (2002) oferecem a seguinte perspectiva de análise:

"Em contraste com a Antropologia social, que privilegia o mundo à exclusão virtual da coisa, nós favorecemos uma Etnoarqueologia que seja o estudo dos humanos no contexto e através de seus trabalhos. Ainda que devamos buscar a compreensão em profundidade de exemplos particulares da diversidade cultural humana, esta necessidade não está em conflito com objetivos definitivamente generalizantes e comparativos. Christine e Todd VanPool (1999) argumentam que, enquanto o pós-processualismo é comumente caracterizado de forma errônea como não-científico, algumas abordagens pósprocessualistas podem, de fato, contribuir para o entendimento científico do registro arqueológico, e por extensão, etnográfico. A coabitação, se não a síntese, é possível. A reflexividade, a hermenêutica e a teoria da prática e as articulações entre elas, podem orientar a prática da Etnoarqueologia interpretativa e podem também ser consideradas ferramentas analíticas essenciais na avaliação tanto de estudos processuais quanto interpretativos.

(...)Stark (1993, p. 96) corretamente caracteriza como um'problema fundamental, compartilhado entre a pesquisa Etnoarqueológica processual e pós-processual: a falta de estruturas metodológicas explícitas.'

A Etnoarqueologia tem sido, em geral, menos influenciada pelo pós-processualismo (Preucel, 1995; Shanks; Tilley, 1989) do que a arqueologia propriamente dita.

(...)

Nesta etapa é mais útil introduzir algumas idéias pós-processualistas que mudaram ou estão mudando a maneira de pensar dos etnoarqueólogos.

Esta afirmação serve para introduzir: uma atitude, reflexividade, que está relacionada à carga teórica dos dados; um procedimento metodológico, o da hermenêutica; e uma teoria, a da prática.

\section{1)reflexividade}

(...)Assim, enquanto "os dados representam uma rede de resistências à apropriação teórica" (Shanks; Tilley, 1987, p. 104), a reflexividade indiretamente abriu o caminho para representações feministas, nativas, e outras assim chamadas representações alternativas do passado e do presente. Isto não quer dizer que não se admita que muitos textos etnoarqueológicos permaneçam fixos num modo naturalista e geralmente não-reflexivo.

\section{2)Hermenêutica.}

(...)é certamente verdade que tanto arqueólogos como etnoarqueólogos trabalham num ire-vir entre a teoria e os dados, construindo, testando e destruindo modelos a fim de construir modelos aperfeiçoados que se encaixem melhor naquilo que é percebido como "o fato". Seja se preferirmos a metáfora do círculo hermenêutico ou a dialética, chegamos gradualmente a compreender a parte em termos do todo e vice-versa

\section{3)teoria da prática}

(..)A teoria da prática é ou deveria ser central à Etnoarqueologia porque ela orienta nossa abordagem de um mundo de indivíduos, sociedades, e coisas materiais e culturais.

Mas Ortner (1984, p. 157) nos lembra que não são apenas as relações de poder que valem ser estudadas nesta perspectiva. "Padrões de cooperação, reciprocidade e solidariedade constituem o outro lado da moeda do ser social... uma visão Hobbesiana da vida social é certamente tão tendenciosa quanto aquela que remete a Rousseau.E ntretanto, mesmo nas sociedades chamadas igualitárias, o comportamento individual é controlado por estruturas coletivas. Assim, por exemplo, quando os povos tribais Baringo estudados por Hodder (1978) usam a cultura material para sinalizar adesões e afiliações étnicas em transformação eles estão, ao mesmo tempo, manipulando estruturas de organização cultural e reconhecendo seu poder. É precisamente porque "os atos 
tecnológicos... são os meios fundamentais através dos quais relações sociais, estruturas de poder, visões de mundo e produção e reprodução social são expressas e definidas" (Dobres; Hoffman, 1994, p. 212), e porque a cultura material ajuda na constituição do mundo dos significados, que a teoria da prática pode ter tal valor para a orientação da pesquisa etnoarqueológica e sua avaliação." (DAVID;KRAMER, 2002:13-60)

A abordagem, nesta pesquisa, portanto, é na experiência em si da prática arqueológica em território indígena. Da 'relação reflexiva' que existe entre pessoas (enquanto agentes) que sofrem e agem sobre estruturas sociopolíticas e culturais.

É esse olhar atento ao cotidiano do arqueólogo em território indígena que dá sentido ao cruzamento de um segundo foco analítico, que é aquele trazido pela disciplina antropológica, a etnografia. À primeira vista pode parecer estranho se fazer uma etnografia de cientistas, mas toda ciência é de certo modo objeto da antropologia. Não há ciência pelo homem que não seja ciência do homem, reveladora do homem.

Como veremos mais adiante, este foco da pesquisa é articulado pelas obras de Latour $(1994 ; 1997 ; 2000 ; 2005)$ e, claro, pelas duas experiências etnográficas que são arqueologicamente orientadas - não sendo uma etnografia densa como aquela proposta por Geertz (1983), mas experiências de campo decorrentes da interface do trabalho arqueológico junto às populações indígenas Terena e Kaiabi.

Recentemente, o conceituado periódico Public Archaeology (volume 8, números 2-3, agosto de 2009) publicou um volume inteiro dedicado à Arqueologia Etnográfica, mostrando diversos exemplos dessa prática diferenciada. A revista chama especial atenção, também, para o questionamento de legados culturais pré-definidos e para a intricada relação entre arqueologia e antropologia. Nesse sentido, vale a pena lembrar a linha teórico-metodológica desenvolvida na Univertiy of Stadford sob o auspício de Michael Shanks, Timothy Webmoor e Christopher Witmore. A arqueologia simétrica, por eles defendida, incorpora preceitos ontológicos desenvolvidos não só na filosofia de Deleuze, mas também no profundo questionamento sobre ciência e cultura, elaborados por Bruno Latour e Roy Wagner.

Esses enfoques analíticos trazem, inevitavelmente, a reflexão epistemológica da arqueologia enquanto ciência. Principalmente quando podemos fazer uma reflexão sobre arqueologia simétrica, ou seja, sobre uma simetrização 
dos estatutos do conhecimento trazido pelos arqueólogos com, que é tão importante quanto, os estatutos de conhecimentos indígenas.

Essa reflexão epistemológica é trazida não somente pelo grupo de pesquisa da University of Stadford de arqueologia simétrica, como também pelos antropólogos Viveiros de Castro e Márcio Goldmam, ambos da UFRJ, que trabalham com a noção de simetria de conhecimentos na antropologia, articulando, justamente, autores como Bruno Latour, Alfred Gell, Marily Strathern, Tim Ingold e Roy Wagner.

\subsection{Arqueologia Simétrica e Reflexiva}

Enquanto se realizava o embate das escolas processuais e pósprocessuais sobre teoria arqueológica, no final dos anos 1980, importantes trabalhos foram desenvolvidos no estudo social do conhecimento científico. Em especial, as obras de Latour e Woolgar (1997, originalmente publicado em 1979), Knorr-Cetina (1981) e Bourdieu $(1974,1984)$ começam a exercer grande influência em outras áreas de conhecimento social.

No Brasil, Roberto Cardoso de Oliveira (2003) chama atenção para a obra de Geertz e de outros autores da História da Ciência (Granger, Gusdorf, Canguilhem e Kuhn) para se pensar uma etnografia do pensamento moderno, mais precisamente sobre uma dimensão desse pensamento, o chamado pensamento 'científico' e a sua transmissão disciplinada.

Geertz em Local Knowledge (1983) foi quem formulou o escopo dessa nova disciplina, a 'Etnografia da Ciência' especialmente no capítulo "The way we think now: Towards an Etnography of Modern Thought'. O caráter provocativo do texto não está somente na ironia de tomar a todos nós, alunos, professores, pesquisadores e acadêmicos em geral como nativos, organizados em comunidades tão fechadas (ou quase) quanto uma aldeia camponesa qualquer, mas está também na relação entre ser e conhecer. Nesse sentido, mesmo os discursos fragmentados da moderna academia são mais do que posições privilegiadas da observação intelectual, "são modos de estar no mundo" (GEERTZ, 1983:155). Esse estar no mundo é visto como princípio fundamental em qualquer trabalho de cunho antropológico e até mesmo arqueológico. Assim, Geertz demonstra a etnografia do pensamento como um empreendimento 
múltiplo, ou seja, "histórico, sociológico, comparativo, interpretativo, qualquer coisa como um corpo a corpo, cuja finalidade é tornar inteligíveis questões obscuras provendo-lhes de um contexto esclarecedor" (1983:152).

Mais focado nos processos de pensamento do que no produto e mais nas conexões sociais do que no contexto, Bruno Latour $(1994,2000,2005)$ qualifica a etnografia da ciência (e talvez até o próprio método etnográfico de pesquisa) a fim de refletir a respeito de uma abordagem simétrica, um aprofundamento sobre o fazer científico e a própria dinâmica de formação de um coletivo (humano e/ou não-humano).

A arqueologia simétrica aborda a relação entre objetos e pessoas, baseada na actor-network-theory (ANT) (LATOUR, 2005). Essa perspectiva teóricometodológica é fruto das discussões sobre qualificações de ontologias primordiais, base do pensamento científico moderno ${ }^{5}$. Antes de refletirmos um pouco mais sobre o que seja arqueologia simétrica e a ANT devemos nos aprofundar sobre as bipolaridades básicas das ciências modernas. O aspecto reflexivo sobre essas questões é o que fundamenta a existência teórica de uma arqueologia simétrica e da ANT.

As ontologias primordiais, caras às ciências modernas (inclusive à arqueologia), estão baseadas em dualismos como passado/presente, sujeito/objeto, significado/significante, representação/representado. Vale lembrar que a relação sujeito/objeto é a pedra madre com a qual se constrói a arqueologia enquanto ciência e é também o ponto comum que perpassa os diversos campos intelectuais que a compõem enquanto disciplina (arqueologia histórica, etnoarqueologia, arqueologia crítica e arqueologia pré-histórica.).

Essas ramificações da abordagem da equação sujeito/objeto, dadas por pesquisadores especializados e por uma multiplicidade de teorias arqueológicas, podem ser agrupadas em duas propostas teóricas: processual e pós-processual (conferir, por exemplo, HODDER, 2001; MESKELL e PREUCEL, 2004; TILLEY, 1993; UCKO, 1995; VANPOOL e VANPOOL, 2003).

\footnotetext{
5 Em Jamais fomos modernos. Ensaio de antropologia simétrica, Bruno Latour (1994) propõe uma concepção teórica que pretende envolver tanto os "não-modernos" quanto os "modernos" no mesmo movimento de compreensão, de seguir o mesmo procedimento de pesquisa e as mesmas exigências de quando se faz antropologia sobre "nós" ou sobre "eles". O que implica a consideração dos termos das suas diferenças. Tarefa esta que é possível com a explanação da ilusão moderna dos grandes divisores epistemológicos, base da ciência moderna.
} 
O gráfico seguinte, de Webmoor (2007a), demonstra o deslocamento dos dualismos ontológicos nas vertentes de pensamento dos processualistas e pósprocessualistas:

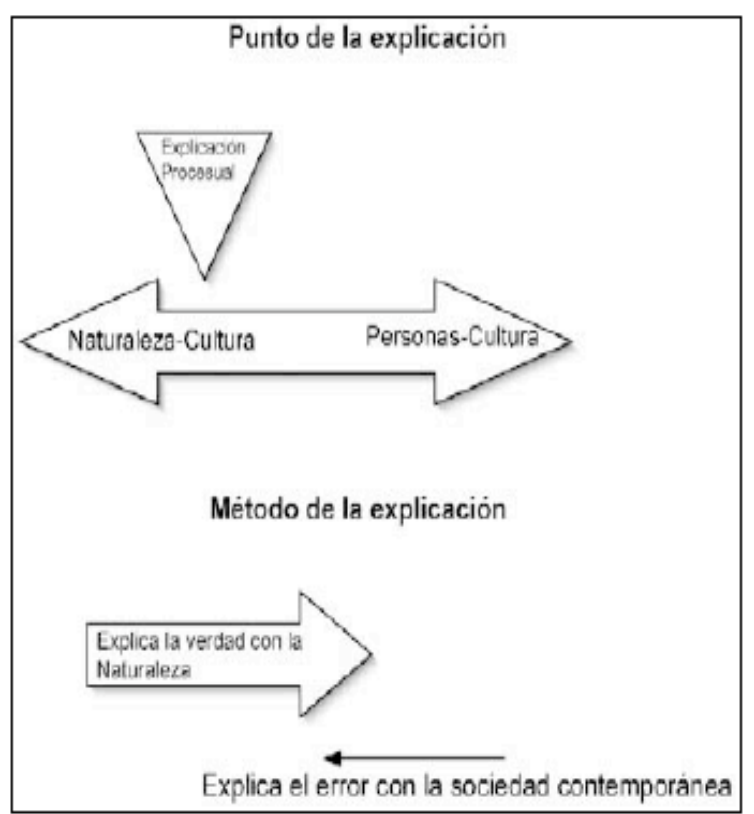

Figura 1.- Mediación de las cosas-personas en la explicación procesual.

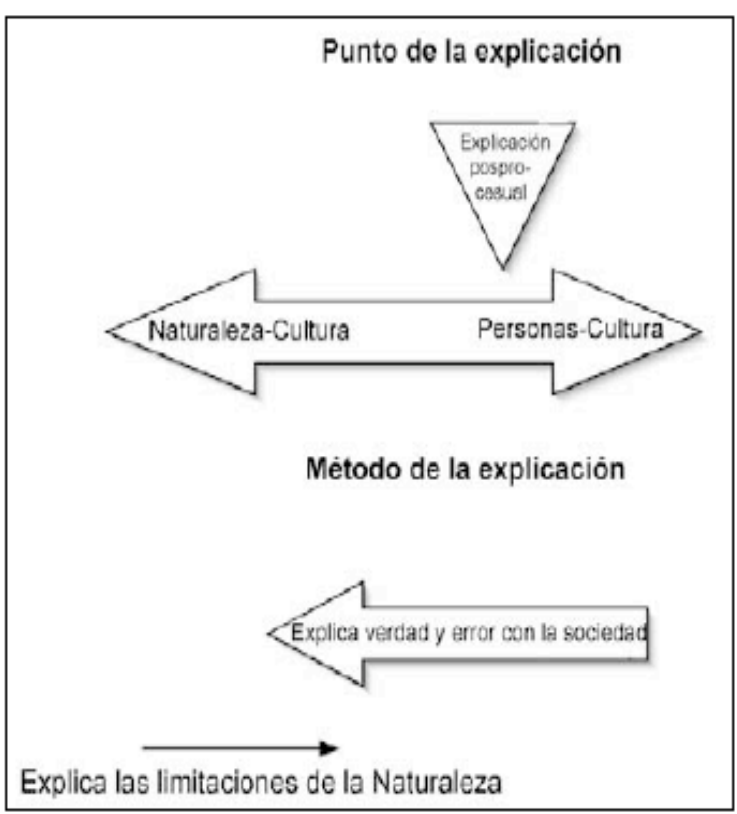

Figura 2.- Mediación de las cosas-personas en la explicación post-procesual.

Portanto, por mais que se amadureça a disciplina, por mais que se fragmentem e se especializem as abordagens, estaremos sempre submersos na circularidade desses dualismos ontológicos (LATOUR 1994; WEBMOOR 2007a; HARAWAY, 2003).

A abordagem simétrica e a ANT rechaçam essa polarização, ou melhor, leva-a em profunda consideração, justamente como uma constante de vigilância epistemológica, o que possibilita uma abordagem original sobre a relação entre coletivos humanos e não-humanos, na primazia de que eles devem ser tratados em termos de igualdade. Isso sendo possível somente com a qualificação da dimensão social $^{6}$, mas não basta dizer que o contexto social é responsável - e limitante - por determinado aspecto de uma disciplina (por exemplo, a dimensão social do direito, a dimensão social da economia, a dimensão social da psicologia, a dimensão social da arqueologia), é preciso tornar visível como as agências

\footnotetext{
6 Baseada na obra de Gabriel Tarde, contemporâneo de Durkein, Latour escreve Assemble the Social, no qual qualifica a dimensão da sociologia para uma abordagem mais ampla do termo 'social'. Coloca em contraste o termo durkheiminiano de fato social, para uma sociedade composta de grupos humanos e nãohumanos (LATOUR, 2005).
} 
(humanas ou não-humanas) formam coletivos sociais e atuam - de forma metafórica - em rede (OLSEN, 2003, 2006).

Alfred Gell (1998), em sua análise sobre antropologia da arte, propõe uma reflexão baseada na noção de 'agência' em vez de 'significado simbólico', o que permitiu sua compreensão da arte como um sistema de ação que tenta mudar o mundo a sua volta e não como um sistema de códigos simbólicos. A sua definição sobre agência (agency) e agente social (social agent), auxilia-nos a compreender como a dinâmica da arqueologia simétrica pode ser entendida, ou seja, como o seu contexto relacional entre coletivos de pessoas e coletivos de objetos pode ser analisado na práxis da disciplina.

\begin{abstract}
"A agência é atribuída a aquelas pessoas (e coisas) que são vistas como seqüências causais iniciais de tipos particulares, isto é, eventos causados por atos da mente ou desejo ou intenção, mais do que a mera concatenação de eventos físicos. (...)

Para o antropólogo, as noções "folk" de agência, tomadas das práticas do dia a dia e das formas discursivas, são as que importam; não as noções de agência filosoficamente sustentadas. (...) A idéia de agência é um marco culturalmente prescrito para pensar acerca (ou sobre) a causalidade, quando o que acontece (em um sentido vago) se supõe compreendido (ou entendido) antecipadamente por alguma pessoa-agente ou coisa-agente. Sempre que acontece um evento por causa de uma "intenção" alojada numa pessoa ou coisa que inicia a seqüência causal, essa é a instancia da "agência"." (tradução minha.GELL 1998:16)
\end{abstract}

Assim, do ponto de vista de Latour, o exercício de simetria (concebido enquanto operação metafórica) está em pensar a relação do observador (no caso desta pesquisa: eu) com os cientistas (arqueólogos), com os coletivos indígenas (no caso: os da Aldeia Lalima e T.I. Kaiabi) e os objetos e seu agenciamento, vinculados a uma prática arqueológica. Portanto, não é uma dualização banal de se pensar cientistas de um lado e indígenas de outro; ou mesmo o objeto de um outro lado, mas focar de modo comparativo as relações entre o observador, os cientistas, os coletivos indígenas e os objetos. Uma relação de relações ou rede de relações, tema próprio das pesquisas desenvolvidas sob a ANT.

A arqueologia simétrica não pesquisa como as pessoas estão no mundo, mas sim como age um coletivo distribuído que negocia uma complexa rede de interações com uma série de entidades diversas (materiais, coisas e "espécies companheiras" (companion species) Haraway, 2003). Dessa forma, a arqueologia simétrica é um programa que pode ser descrito como uma nova "ecologia" cheia de coisas e humanos que dá prioridade à presença multitemporal e multisensorial do mundo material (WITMORE, 2006a, 2006b, 2007; WEBMOOR, 2007a, 2007b; 
GONZALEZ-RUIBAL, 2007; OLSEN, 2003, 2006; SHANKS, 2007). Essas entidades diversas podem ser refletidas seguindo a sugestão de Webmoor através da multivocalidade dos agentes em campo:

"El creciente debate sobre multivocalidad - o el imperativo ético de incorporar a los individuos afectados e interessados em la interpretacion arqueológica - puede ser un elemento diagnóstico del futuro que espera tales programas inconmensurable. [Programas de arqueologia simétrica que não podem ser mensuráveis através do deslocamento natureza/cultura - pessoas/culturas, apontado nos gráficos anteriores]. Las aproximaciones multivocales se han desarrollado a partir de las llamadas de atención dentro de la propria disciplina, que exigen tener cuenta el contexto sóciopolítico contemporáneo del trabajo arqueológico, así como a partir de mandatos legales externos e independientes. Estas aproximaciones colaboran a la desacreditacion de dicotomias heredadas, como passado-presente $y$ objetividadsubjetividad." (WEBMOOR, 2007:299)

Agora, deixemos de lado a definição pela negação e passemos para as implicações da prática reflexiva na arqueologia. O gráfico abaixo (WEBMOOR, 2007a) possibilita a compreensão do sentido do uso, inclusive nesta pesquisa, de termos tais como "prática", "agências", "representação", "mudança" e "tempo". Pode-se notar que eles são configurados em um sistema analítico mais complexo; os termos passam a ser relacionados como a um emaranhado de coletivos humanos e não-humanos, fugindo assim, da noção anterior de categorias de pensamento pertencentes a um pólo ou a outro, como demonstrado nos gráficos anteriores. 


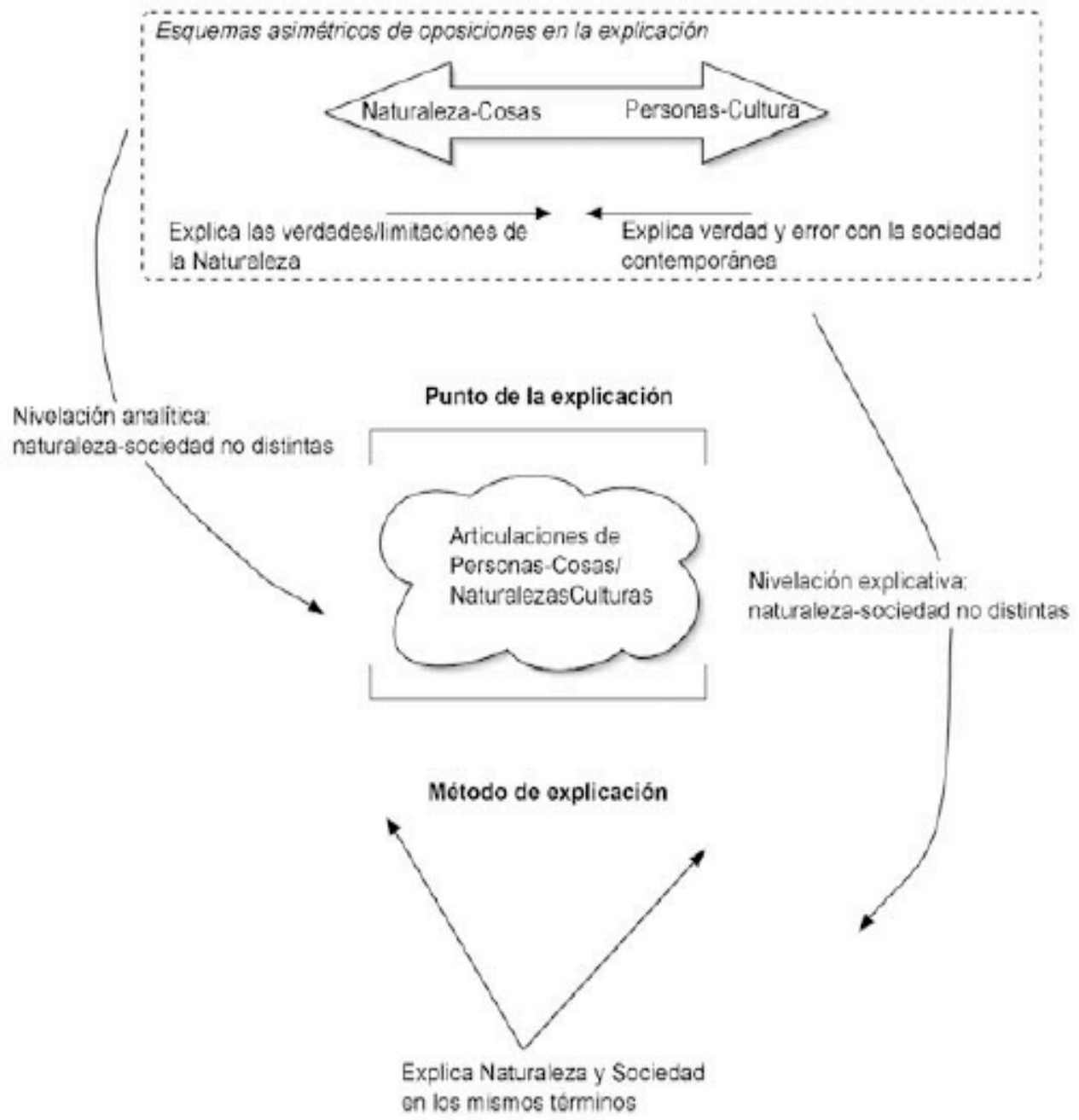

Figura 3.- Personas-cosas en la explicación simétrica.

Um bom exemplo desse processo é o citado por Webmoor sobre arqueologia pré-colombiana:

"Por ejemplo, la cerâmica naranja común se encuentra em Teotihuacán durante toda la ocupación del sítio (aprox. 100 a.C.600 d.C.). Más que distinguir estos objetos de la gente que los utilizó, la arqueologia simétrica tratará a los teotihuacanos y a la cerámica naranja del período como algo inextricable - como un conjunto o colectivo. Para entender la práctica prehistorica $i$ es útil distinguir a los usuários de las omnipresentes cerâmicas de las próprias cerámicas?" (WEBMOOR, 2007a:301)

Antes de tudo, portanto, é importante pontuar de onde parte o presente trabalho. Ele não é uma reflexão pós-processual, muito menos um trabalho pósmoderno, já que o deslizamento do sufixo pós implica em jogar para o além a questão cultural - que reflete, de certa forma, a constante segmentação da disciplina. Também não tenho a pretensão de elaborar uma história do 
pensamento arqueológico ${ }^{7}$. Nesta pesquisa a questão cultural se refere à prática científica da arqueologia contemporânea, em especial àquela que é realizada em território indígena. Isso implica na reflexão sobre regimes culturais associados a representações de cultura e "cultura".

\begin{abstract}
"Culture has to be understood as operating simultaneously at two levels. For the sake of the argument let us call them a literal and meta-level, although the two are interconnected and it is difficult to ascribe 'literality' to one rather to the other. Anyway, by literal, I mean than to the other. Anyway, by literal I mean what anthropologists up to some time ago, used to call culture, something that though dynamic and changeable, would inform values and actions (...) there is an internal organization to culture in that literal sense, an organization that will constrain and inflect changes. At another level 'culture' As a Whole is used diacritically to separate people, to discriminate in both the etymological and the current sense. This is 'culture' as political discourse." (CARNEIRO DA CUNHA 2002:8)
\end{abstract}

A reflexão aqui elaborada tem, portanto, suas bases na antropologia, na vivência e na formação em ser um arqueólogo, que atua em território indígena.

Ao etnografar como os arqueólogos se relacionam para fazer ciência, acabo por descrever os seus modos de sociabilidade, assim como as 'invenções' que são obrigados a fazer a fim de estabelecerem relações, como veremos nos capítulos seguintes.

Uma das vantagens em se trabalhar com arqueólogos que trabalham em território indígena é contrastar as diferentes discursividades que esses dois grupos elaboram (arqueólogos e população indígena) em torno do vestígio arqueológico. Isso é um exercício reflexivo próximo ao que Strathern (1988) propõe em Gênero da dádiva, no qual, em vez de simplesmente colocar em relação duas sociedades ou duas culturas, de acordo com o antigo método comparativo, ela coloca em conexão a multiplicidade de práticas discursivas.

\title{
1.4 A experiência etnográfica.
}

Falar "método etnográfico" no singular é quase uma armadilha: é importante ter em conta a diversidade de sociedades e culturas assim como as situações em campo. A personalidade e a trajetória do pesquisador ou dos pesquisadores no estabelecimento das relações em campo, por outro lado, não

\footnotetext{
Tal tarefa já foi bem elaborada por TRIGUER (2004) ou, no caso brasileiro, por NOELLI; FERREIRA (2007) ou ainda por Poloni (2008) sobre Etnoarqueologia no Brasil.
} 
torna possível o estabelecimento de uma única metodologia, tão característica às etnografias clássicas.

Isso posto, e sem entrar em contradição com a premissa de que a coleta de determinadas informações ou dados necessita da aplicação de técnicas especificas, podemos, no contexto etnográfico, delinear genealogias ou uma terminologia de parentesco; estabelecer padrões em certos coletivos sociais que são construídos pelo pesquisador, mas que também se autoconstroem; estudar um sistema cultural, entre outras atividades, apenas para estabelecer alguns exemplos de técnicas de campo submetidas à implementação de algumas ações específicas.

Na verdade, a especificidade da pesquisa etnográfica em um contexto etnoarqueológico precisa ser procurada, entre outros, no dispositivo da fala, mas também na observação participante inaugurada, teórica e praticamente, por Bronislaw Malinowski já há mais de um século. Esse tipo de aproximação ao objeto de estudo constitui, entre outras, a aproximação antropológica aos fenômenos sociais e culturais. Fato que propõe a construção de um "campo" onde o pesquisador aceita se submergir transformando-se não somente em pesquisador, mas também em pesquisado. Essa foi a linha seguida na Aldeia Lalima e na Terra Indígena Kaiabi, onde a epistemologia arqueológica pôde ser observada no decorrer da sua própria elaboração.

Os etnólogos designam como campo o lugar para o qual se deslocam a fim de observar a vida de uma sociedade e recolher sobre ela as informações diretamente proporcionadas pelos interlocutores escolhidos ou por aqueles que nos escolhem. Daí que o trabalho etnográfico por excelência é o trabalho de campo, sendo a situação etnográfica a situação de campo. Porém, na minha pesquisa, o campo não ficou restrito à Aldeia Lalima e à Terra Indígena Kaiabi. Trabalhando com arqueólogos na própria construção do dado e na interpretação arqueológica, esse campo se estendeu à cidade de São Paulo, mais precisamente, ao Museu de Arqueologia e Etnologia da Universidade de São Paulo. Nesse espaço que se prepararam as expedições arqueológicas constituindo-o, portanto, em um "sítio" ideal para acompanhar o processo da minha pesquisa. As situações sociais compartilhadas com os membros do grupo, tais como: viagens, noites nos hotéis das cidades antes de começar a viagem para as aldeias, churrascos informais e até mesmo a famosa cerveja depois de 
um dia de trabalho formaram um corpus de apoio para pensar as problemáticas apresentadas.

As particularidades materiais e morais desse tipo de situação têm sido evocadas pelos pesquisadores em muitas obras bem diferentes. Não podemos deixar de mencionar Malinowski (Um diário no sentido estrito do termo, 1997), Mauss (Manual de Etnografia, 2009) ou Levi-Strauss (Tristes Trópicos, 1996), entre outros. Como assegura Gonçalves da Silva:

"Reflexões sobre o trabalho de campo feitas apenas em termos do que ele é em si mesmo ou de como aparece nas introduções metodológicas ou nos outros capítulos do texto etnográfico podem ocultar, entretanto, outras questões mais pertinentes, a meu ver, sobre a natureza do próprio trabalho de campo. Se um dos principais objetivos da antropologia é promover um alargamento da razão possibilitado pelo conhecimento das várias concepções do mundo presentes nas culturas diversas (considerando-se que as culturas só se encontram através dos encontros dos homens), o trabalho de campo é um momento privilegiado para o exercício desse objetivo, pois é nele que a alteridade, premissa do conhecimento antropológico, se realiza" (SILVA, V. G.2006:25)

Nesse sentido, meu trabalho de pesquisa foi um momento realmente privilegiado para o encontro não somente de culturas em interação, mas de uma disciplina específica tentando - e podendo - elaborar uma determinada produção decorrente do encontro de epistemologias diversas. E de fato, a possibilidade de ampliação de uma teoria do conhecimento arqueológico passa não só pela interação com as culturas kaiabis e terena, mas também pela teoria etnográfica própria da disciplina antropológica.

É preciso mencionar que a minha inserção no campo só foi possível devido à longa vivência e diálogo que os dois arqueólogos (Eduardo Bespalez e Francisco Forte Stuchi) haviam estabelecido com a Aldeia Lalima e a Terra Indígena Kaiabi, desde 2004, facilitando todo o processo de negociação da pesquisa e elaboração das licenças. Atualmente, Francisco Forte Stuchi desenvolve sua pesquisa de mestrado em arqueologia sobre a ocupação territorial kaiabi e Eduardo Bespalez o seu doutorado sobre arqueologia em Lalima.

Assim, também é preciso estabelecer quais foram os interlocutores no campo que interagiram perante a minha curiosidade e, muitas vezes, a minha 
insistência. Obviamente, os Kaiabi e os Terena foram interlocutores vitais para a compreensão do que é 'fazer ciência' desde a perspectiva desses sujeitos.

Os arqueólogos presentes nas duas pesquisas, que compreenderam e apoiaram a minha atividade em campo, conformaram a "outra parte" da pesquisa. Esses atores mencionados não foram os únicos. Também foi valorosa na construção do meu campo a interação com o topógrafo, os motoristas, as enfermeiras do posto indígena e, até mesmo, os gerentes de hotéis locais.

Dito isto, gostaria de reforçar que, na minha perspectiva, todos os atores envolvidos na pesquisa colocaram em campo não somente a ação de pesquisar e/ou ser pesquisado bem como suas próprias trajetórias individuais e sociais. Por exemplo, não é à toa que diferentes membros da equipe de arqueólogos tenham tido uma determinada trajetória disciplinar em diferentes tradições acadêmicas (história, biologia, ciências sociais). De fato, acho que a formação em disciplinas diferentes influência de diversas maneiras a prática da arqueologia. Isso surge fortemente em campo e pode ser observada, em minha etnografia, nos registros das diversas maneiras de pensar a arqueologia ---- tal perspectiva pode ser observada nas falas transcritas dos arqueólogos. .

$\mathrm{E}$, dialeticamente, o mesmo campo afeta os pesquisadores. No entanto, como assegura Peirano (1995:346) "A meu parecer, o impacto profundo de pesquisa de campo sobre os etnólogos ainda não recebeu a sua devida atenção."

A mesma premissa pode ser aplicada à prática arqueológica em geral e, talvez forçando a generalização, a todas as disciplinas que interagem com atores e coletivos tentando problematizar diversos aspectos da dinâmica social ${ }^{8}$.

Neste sentido, uma parte importante - senão a mais importante - desse trabalho tratou de pensar essas articulações. À maneira de Gonçalves da Silva -“... de que modo as condições de coleta dos dados de campo, ao envolver

\footnotetext{
8 "No decorrer do século, contudo, houve um momento crítico. Foi quando se pensou que a pesquisa de campo desapareceria pela recusa dos nativos, agora cidadãos de nações independentes, em aceitar a presença dos antropólogos. Esta situação, que culminou nos anos 60 , levou indiretamente a uma explicitação de alguns pressupostos da disciplina: frente ao perigo do desaparecimento do suposto objeto concreto da antropologia, Lévi-Strauss enfatizou, com otimismo, que à disciplina interessavam principalmente as diferenças, que nunca seriam eliminadas (1962). Na Inglaterra, Jack Goody reconheceu que, agora que os Nuer elegiam membros do Parlamento, os Navaho possuiam seus próprios poços de petróleo e os Tallensi, escolas primárias, a era das explicações "totalizadoras" chegava ao fim e a antropologia só seria viável daí em diante como um tipo de arqueologia social ou como pesquisa histórica" (PEIRANO 1995:6)
} 
dimensões como a intersubjetividade e as relações de poder estabelecidas entre antropólogos e o grupo estudado, afetam as interpretações produzidas e são referidas no próprio texto etnográfico..."(2006:14)-- e a relação que eu faço da metáfora do uso de redes. Se definirmos 'texto' em sentido amplo, não seriam eles, os índios com quem trabalhamos que também produzem um 'texto' sobre nós? Somos nós que viemos de longe a intervir nas suas terras, no seu cotidiano, a produzir um "estado de exceção" - como definiria Agamben (2001:37) sobre o campo - que implicitamente reflete o próprio texto etnográfico.

Partindo desses horizontes de pesquisa, comecei minha própria experiência etnográfica tentando perpassar essas diferentes reflexões teóricometodológicas sobre o campo etnográfico. Assim, foram dois campos de investigação com preocupações e abordagens semelhantes e diferenciadas. No primeiro campo, realizado em 2007, fiz parte de uma equipe de arqueólogos em uma escavação em área indígena na Aldeia Lalima (Miranda, MS). A abordagem etnográfica foi centrada no desenvolvimento da pesquisa arqueológica, no "fazer ciência" e suas conexões sociais resultantes.

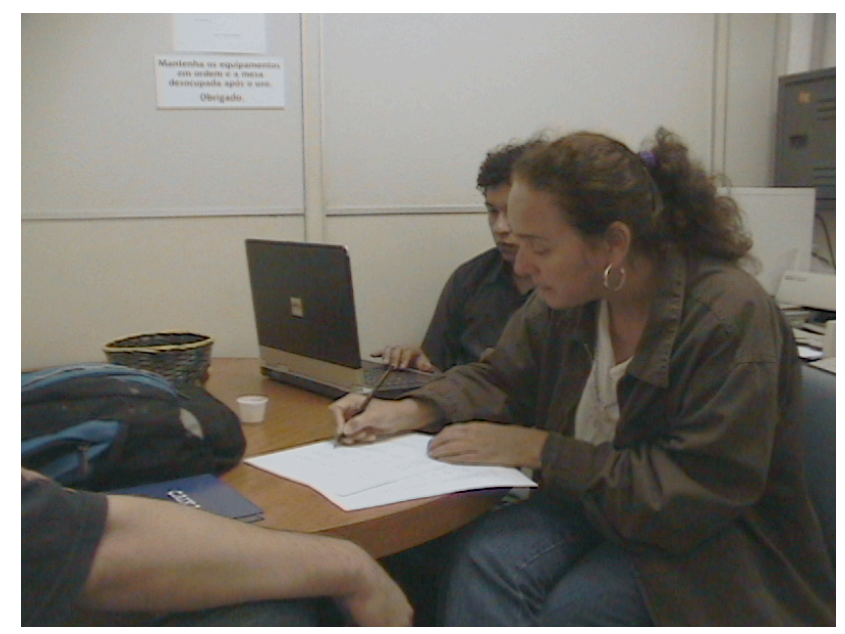

Uma das reuniões de operacionalização do projeto, no Museu de Arqueologia e Etnologia (MAE-USP)

No segundo campo etnográfico, no ano seguinte, fomos para a Terra Indígena Kaiabi (Alta Floresta, MT). A abordagem etnográfica, nesse caso, foi focada na percepção indígena do trabalho arqueológico.

As cenas e diálogos descritos, em ambos os campos, suscitam conexões com outros coletivos (humanos ou não-humanos), sempre seguindo a proposta 
etnográfica de Latour, de actor-network theory (2005), que evidencia os diversos agentes e agências sobre os quais se dá a descrição etnográfica, sugerindo diversas linhas de reflexão, como já abordado nos aspectos teóricometodológicos.

Como uma análise científica pressupõe um recorte analítico, não será possível explorar todas as linhas reflexivas e aspectos culturais. Durante o texto etnográfico, vou mostrar algumas conexões possíveis, mas sem esgotá-las, como, por exemplo, a relação entre dinâmicas políticas e a construção do dado arqueológico.

Um outro ponto que devo ressaltar aqui é que visando preservar a identidade dos meus interlocutores, decidi omitir os seus nomes, pois o objetivo não é expor os indivíduos em si, mas expor a fluidez das agências na descrição etnográfica.

Todos os relatos apresentados aqui foram gravados durante o campo. Apesar das gravações terem sido feitas em português, foram necessárias algumas edições no momento de se adequar a fala gravada(ou discurso gravado) dos atores a um texto escrito. Visando preservar a qualidade de se trabalhar com uma fonte primária(Tedlock, 1983), foram preservadas repetições e tentou-se alterar o mínimo possível as características lingüísticas do português falado por esses sujeitos, dessa forma, as transcrições não foram feitas seguindo a norma padrão do português brasileiro escrito

E por fim, seguindo a leitura de Richard Price $(2004)^{9}$ e a sua preocupação em mostrar as múltiplas vozes da história Saramaka, procurei apresentar as etnografias de forma que se pudesse proceder, concomitantemente, a leitura da análise etnográfica e da transcrição das situações que propiciaram esta análise. Ou seja, nos dois capítulos apresentados sobre as experiências etnográficas kaiabi e terena, podemos encontrar na mesma página, a preocupação de se

\footnotetext{
9 “Também aqui me declaro culpado - meu livro First-Time (Price, 1983) estava extremamente preocupado em repre- sentar "verdades parciais" e apresentar narrativas alternativas e múltiplas vozes históricas que, nas palavras de Natalie Davis, "nos permitem imaginar novas possibilidades tanto para a história como para a memória” (Davis, 1999, p. 26)

Ele expunha as versões destes sobre seu passado (em traduções verbatim na parte superior de cada página) e (numa coluna em corpo diferente na parte inferior de cada página) apresentava relatos dos mesmos eventos extraídos de documentos holandeses contemporâneos, hoje armazenados em arquivos nos Países Baixos."(2004:299-300)
} 
manter a articulação da voz primária de um contexto etnográfico com sua reflexão epistemológica.

Mapa de localização das áreas pesquisadas

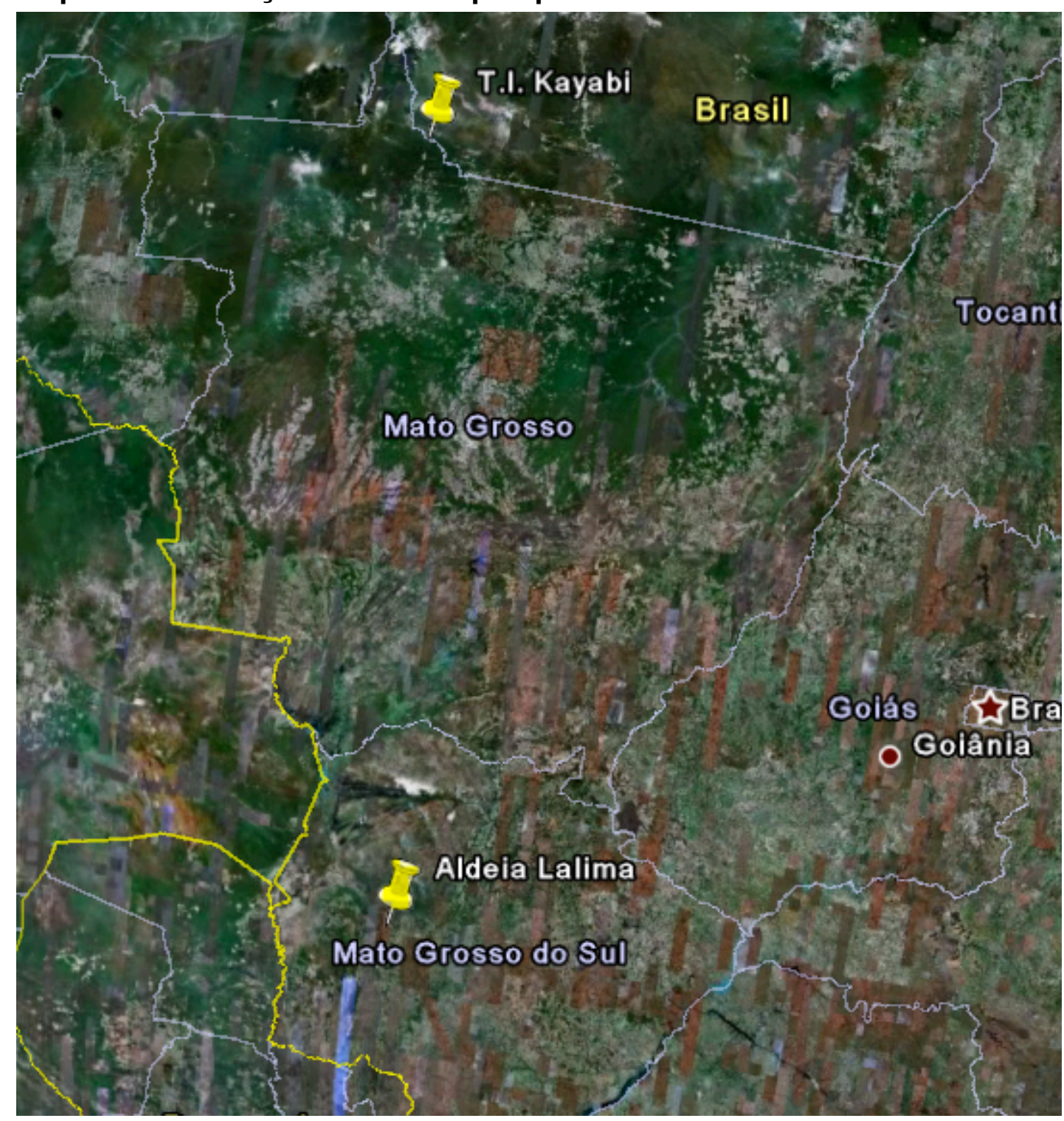




\section{Capitulo 2}

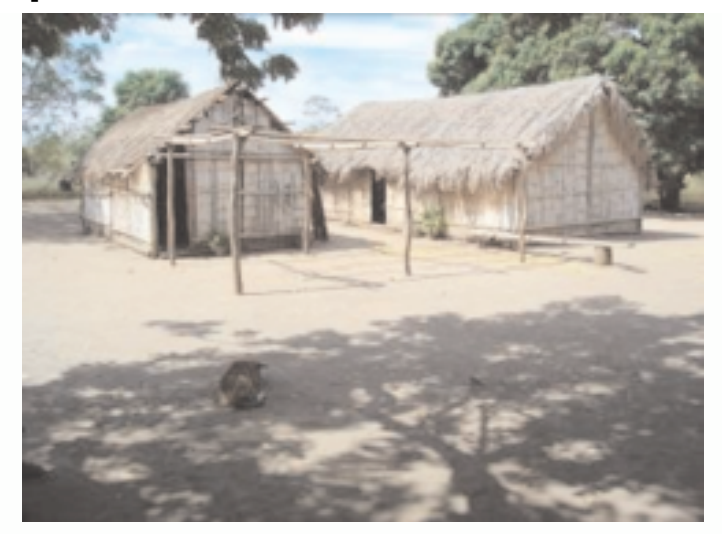

Casas de Lalima

\section{A experiência etnográfica em} Lalima

As principais fontes etnográficas sobre os Terena podem ser encontradas nos trabalhos de Cardoso de Oliveira (1976;1983;1959;1976;1966), Gilberto Azanha (2000; 2004); Max Schimidt (1917); além de naturalistas como Felix Azara (1809), Francis Castelnau (1850), Nimuendajú (2002) e Taunay (1940; 1951). Pertencente ao tronco lingüístico Aruak, a língua Terena é falada em

algumas aldeias, no entanto, o seu uso e fluência são desiguais nas várias comunidades Terena. Este é o caso de Lalima, onde poucas pessoas falam Terena no cotidiano, apesar de haver, na escola indígena da aldeia, o ensino da língua Terena. Os Terena, não apenas os de Lalima são inseridos no campesinato sul-matogrossense pelo senso comum local (OLIVEIRA, 1976). Mesmo tendo vivido um forte processo de integração, eles são identificados localmente e se identificam como índios, além de exercerem um poder de indigenização sobre a cultura local, principalmente nos municípios mais próximos das aldeias (AZANHA, 2004). É admirável a organização política dos Terena da região de Miranda frente à prefeitura local, no que tange o atendimento a suas demandas, tais como o acesso à energia elétrica, à gestão educacional e o acesso à cidade etc. $O$ que torna Lalima mais interessante do que outras aldeias da região do município de Miranda são as confluências culturais que existem nela, tanto do ponto de vista arqueológico (BESPALEZ, 2009) como do ponto de vista antropológico (OLIVEIRA,1976). Nas entrevistas, quando questionados sobre suas etnias, foi comum ouvir "Terena com

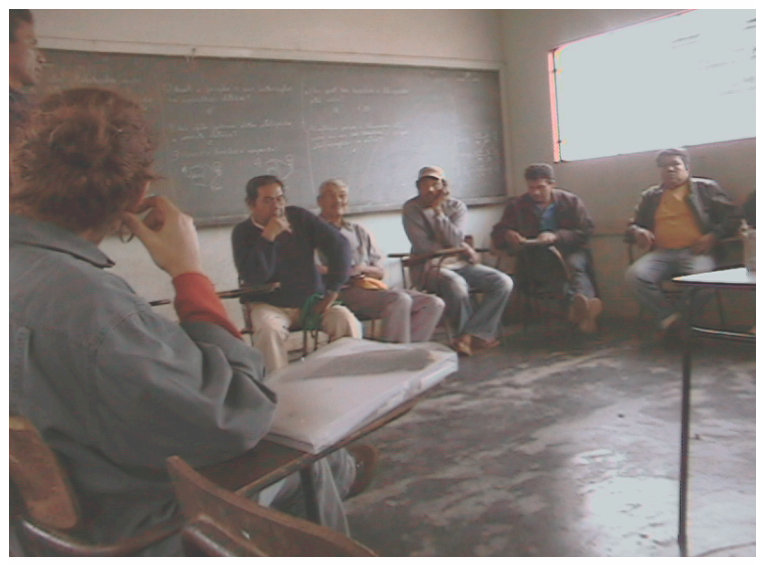

Reunião com o conselho
Primeira Reunião com o cacique e as lideranças no Conselho Indígena da aldeia Lalima.

Cacique: Bom dia. Bom, então, como o Arqueólogo1 e sua equipe procuraram o encontro, eles entraram em contato e vieram até aqui, mas eu não os conhecia pessoalmente. Aí, eles vieram estudar e ver o que ficou combinado com o último cacique, e eu falei para ele que nós estamos aí em $120(\mathrm{~km} / \mathrm{h}$ ) começando (a nova gestão do Conselho). Então, eu achei melhor que nós fizéssemos essa reunião com eles se apresentando. Todos aí na reunião que tiverem 
Kinikinau", "Terena com Laiana" ou "Terena com Kadiweu" e até mesmo "Terena Puro", em contraste com as outras 'misturas'. Além desses, existe um outro conjunto na autoidentificação étnica da aldeia que são os Guaicuru, possuidores de um discurso um pouco mais inflamado - no sentido da afirmação étnica - do que os demais, mas ao mesmo tempo mais tímidos no primeiro contato da pesquisa. Ainda que de forma implícita, esse mosaico étnico vinculado a um sistema de parentelas joga com as dinâmicas de poder local, seja no conselho das lideranças ou em outras agências como a escola, a Associação Indígena, igrejas (evangélicas e católica) e até mesmo o comando do posto da Funai. Assim, sobre a formação da aldeia e sua característica multiétnica Gilberto Azanha nos oferece a seguinte análise:

"A história da criação desta Reserva é controversa e, até onde sabemos, não existe pesquisa ainda feita para levantar os dados históricos da sua constituição. Segundo Cardoso de Oliveira (1976:75-76), documentos do antigo Serviço de Proteção aos Í ndios (SPI) indicariam que a área teria sido reservada pela "monarquia" (sic). Contudo, no trabalho de Carvalho \& Carvalho (1999) não encontramos qualquer menção à I ocalidade "Lalima". A história oral dos idosos habitantes da Reserva colhida por Cardoso de Oliveira parece ser mais coerente com os documentos que dispomos. Nestes relatos, os mais antigos habitantes, descendentes de índios "Guaicuru", afirmavam que a área teria sido solicitada ao Governo do Mato Grosso por Rondon, ao tempo da construção das linhas telegráficas (Cardoso de Oliveira, op. cit.: 75). De fato, a formação original da população de Lalima parece ser de remanescentes da etnia Guaicuru (Mbayá). Nos documentos da titulação primitiva de imóveis situados

perguntas tirem as suas dúvidas juntamente com eles que eles vão esclarecer. Nós não apresentamos a liderança á comunidade ainda e nem eles sabem quem são. Mas todas as lideranças que estão aqui são pessoas daqui da nossa comunidade. E a gente tem esse respeito, eu trabalho aqui direto na comunidade desde que a gente assumiu, a gente quer trabalhar aí junto com eles, e se eles perceberem alguma coisa que a gente não está atendendo, eles têm direito de falar e pedir o afastamento, a gente tem essa consciência aqui para defender aquilo que é melhor para toda a nossa sociedade da aldeia Lalima. Então aqui está o antigo vicecacique que trabalha ainda na nossa gestão... agora os outros, ainda vão ser apresentados numa reunião para vocês (o conselho e a comunidade) no sábado seguinte, mas essa reunião é à parte. Eu vou começar a apresentar o vice-cacique que vai fazer parte dessa gestão, o ex-cacique, as lideranças que vão fazer parte, um ex-cacique e o Presidente da Associação. Vão falar com vocês.

Arqueólogo1: Antes de mais nada, primeiro eu acho que vocês estão corretos, é uma atitude louvável, o pessoal agora, que todos estejam se organizando, acho que é a assim que as coisas funcionam. Assim que eu soube que tinha mudado de cacique e o conselho tribal, uma das primeiras coisas que a gente fez foi vir aqui conversar com os senhores, conhecer os senhores e apresentar e dizer que a gente concorda com tudo isso, e sempre quando vocês precisarem da gente, não só vocês, mas qualquer pessoa, precisar de alguma informação sobre o nosso trabalho, a gente tem o maior prazer em dar todas as informações. Até porque são nessas 
nos limites da área atual, indicavam o "aldeamento Guaicuru" ou "Colônia Guaicuru"(...) Ao que tudo indica, a Reserva de Lalima foi proposta pelo SPI - e reconhecida pelo Governo do Estado do Mato Grosso, como determinava a legislação da época - em meados da década de 1920 nos seus atuais 3 mil hectares. Contudo, somente na década de 1980 o Governo Federal tomaria a iniciativa de regularizar a área." (AZANHA, 2004:29)

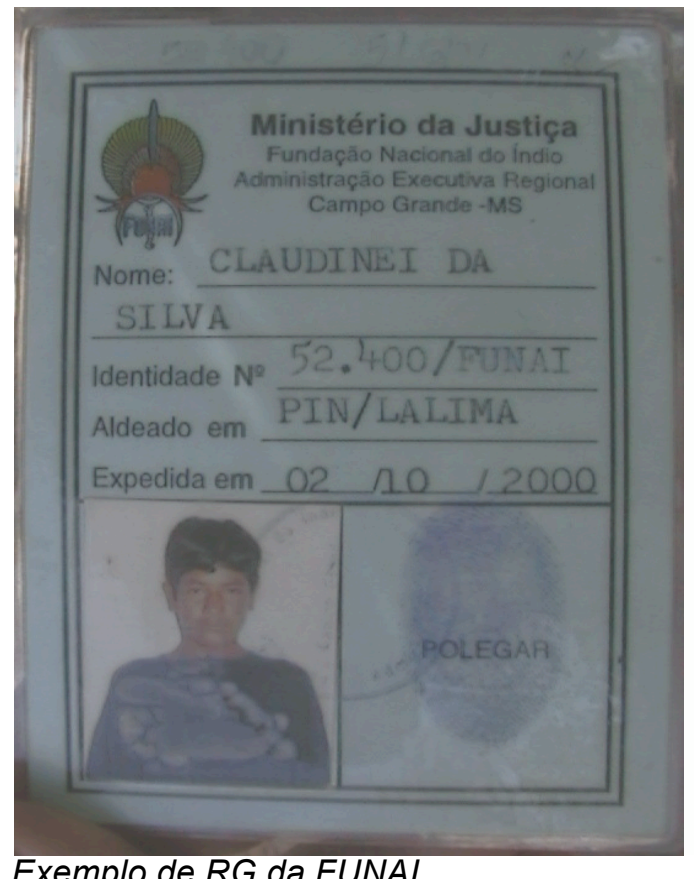

\section{Nome de Lalima}

O próprio nome da aldeia já levanta algumas pistas sobre a historiografia local pela percepção nativa, especialmente refletida na memória dos anciões. Apesar de haverem interpretações diferenciadas, algumas qualidades argumentativas podem ser ressaltadas, especialmente aquela que se refere às incursões da etnia Kadiwéu. Aparentemente, esta é responsável pelo batismo da aldeia e por uma longa rede de contatos sociais.

Exemplo de RG da FUNAI

Arqueólogo3: Aqui chamava como?

Ancião2: Pirizal mesmo... ali naquelas casas próximo ao mangueirão bem na curva ali, onde está aquele mato ali tem um pé de piúva [ ipê- amarelo], ali tem o córrego do Lalima

Arqueólogo3: Porque que chama Lalima? Ancião1: Lalimaga..... No idioma kadiwéu. Arqueólogo3: E o que significa "lalimaga"

conversas que a gente consegue arrumar os dados e fazer o nosso trabalho, como eu estava conversando com o antigo ex-cacique e ele falou para a gente que ele encontrou um documento alegando que essas terras aqui são consideradas devolutas desde 1904 e, pelas informações que eu tinha, era desde 1905. Então são nessas conversas que nós vamos acrescentando dados.

Então essas conversas são sempre boas porque é conversando que a gente se entende.

Arqueólogo2: O Arqueólogo1 vocês já conhecem, acho que eu vou me apresentar e contar um pouco para vocês o que a gente está trabalhando aqui, na verdade, eu sou uma acadêmica, eu sou professora da Universidade de São Paulo e eu trabalho em aldeias indígenas há muitos anos. Eu já trabalhei em diferentes grupos, em diferentes populações indígenas, especialmente na Amazônica, onde eu tenho um trabalho de muitos anos. E na verdade eu sempre me interessei muito em estudar a história das populações indígenas. $\mathrm{Eu}$ sou antropóloga, sou arqueóloga e sou professora, na verdade, há quase 20 anos. E eu vinha fazendo o meu trabalho nesses anos 
Ancião1: "Quando chegaram aqui o sol ia entrando"

Arqueólogo3: Alguém me contou que a aldeia Lalima se chama assim por causa da porteira que tinha uma lima, agora eu não sei dizer, cada um conta uma história. Por que se chama aldeia Lalima?

Ancião3: Na verdade não é bem Lalima. Aqui é feito pelo tempo que meu finado avô contava, que ele que conheceu o começo daqui, o finado Inocêncio Veio, ele era meio guaicuru meio com kadiwéu. Então foram eles que conheceram aqui, mas antes disso já existia os antepassados, os caciques velhos. Então esse cacique chamava Inocêncio, mas ele era guaicuru com kadiwéu.

Então eles diziam o seguinte, que esse lugar chamavam Lalimaga.

Arqueólogo3: Lalimaga?

Ancião3: Lalimaga, aí no passar do tempo, o senhor sabe, que os brancos depois mudam né, e eles passar a falar Lalima, aldeia Lalima. Então fizeram, Lalima, mas na verdade ela é Lalimaga, no idioma kadiwéu que significa 'toca de onça', na verdade. Pois ela se escondia lá. Então esse Inocêncio Velho caçava onça e ela corria diretinho para lá. Então colocaram o nome do lugar de toca da onça no idioma kadiwéu, então ficou esse lugar chamado assim, por isso que não é Lalima.

Ou mesmo segundo Bespalez (2009:70) "Ao que os Guaikurú nos disseram enquanto realizávamos a pesquisa arqueológica, o termo Lalima é uma corruptela da palavra lalímaga, que significa "terra do sol poente."

Segundo Souza (2007) 'Lalima' tem o seu nome na palavra 'Lalimagadi', no idioma Kadiwéu, que significa sumidouro . Apesar das interpretações diferenciadas nas falas

todos, e mesmo querendo discutir a antropologia indígena, sempre tem muitos problemas, muita demanda, então eu sempre quis que $\mathrm{o}$ meu trabalho ajudasse especialmente na área de educação indígena. Então eu sempre tive esse tipo de preocupação de contar a história das populações e ajudar na formação de professores indígenas e essas coisas todas. Estudar a cultura indígena, preservar a cultura indígena também, a gente sabe que são coisas extremamente importantes, a própria manutenção das terras indígenas depende disso também, como o senhor mesmo estava falando, essa questão de ser índio aldeão, colônia indígena e todos esses questionamentos que a Funai sempre fez e que o governo faz, 'não é mais índio porque é assim', 'você deixou de ser índio'.

Então, isso sempre foi uma preocupação minha e da minha equipe, da gente ajudar essas populações a conseguir se manter, na sua identidade, na sua história, preservar essas coisas todas, preservar seus direitos sobre suas terras, tudo isso e ao mesmo tempo ter uma vida digna também, ser reconhecido... Então, eu estava fazendo o meu trabalho, como eu disse, durante muitos anos e o Arqueólogo1 apareceu com essa proposta de pesquisa porque ele é daqui de Campo Grande, Mato Grosso do Sul, e tudo mais. Ele já conhecia a aldeia e que já tinha vindo com outro professor aqui e ele disse que achava interessante a gente começar a pesquisa lá e que gostaria de fazer a pesquisa de mestrado em Lalima, contar toda história de ocupação daquela região, daquela aldeia e eu disse bom, é uma coisa interessante e se a comunidade quiser a gente pode fazer um investimento 
dos anciões acima, o fato de o nome se referir a um topônimo é evidente, seja pela referência de toca ou lugar da entrada do sol, o que condiz com a interpretação de Souza sobre a dinâmica de nomeação indígena Kadiwéu.

"A análise da especialidade indígena Kadiwéu, por meio de histórias de outros espaços-tempos, permite ao pesquisador repensar categorias ditas geográficas, tais como lugar, região, território e paisagem, através das informações orais fornecidas pelos Kadiwéu. $\mathrm{Na}$ fase de maior mobilidade, esses índios percorreram extensas áreas do atual Estado de Mato Grosso do Sul e os lugares em que paravam foram "batizados" por topônimos que perduram até hoje e se transformaram em referência, inclusive para os não-índios. Aquidauana, Betione, Lalima, Nabileque e Niutaca são exemplos de topônimos extraídos da língua Kadiwéu. Embora representem, atualmente, locais do Estado de Mato Grosso do Sul, no passado constituíram o extenso território dominado pelos Kadiwéu." (SOUZA, 2008:56)

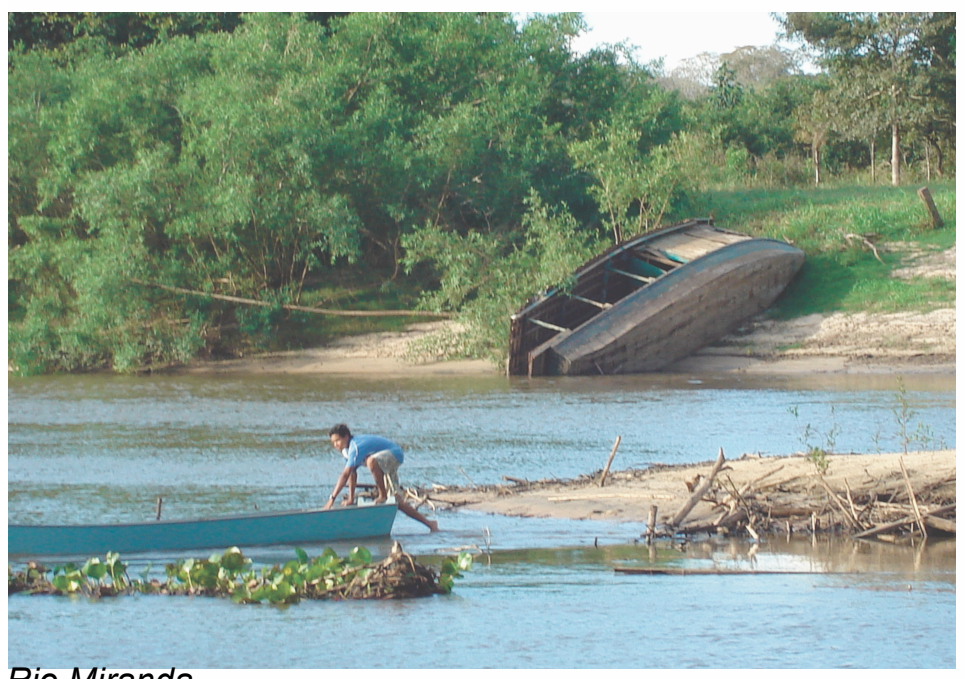

\section{Índios fugidos, formação contemporânea de Lalima e a relação regional}

Pesquisas que possuem caráter pós-processual ainda são pouco exploradas na região do pantanal (OLIVEIRA, 2000). A abordagem arqueológica sobre o contato encontra grandes possibilidades de desenvolvimento na bacia platina, principalmente quando referimos a Guerra do Paraguai e pressões colonialistas. Um exemplo dessa prática pode ser encontrado no livro "The Archaeology of Difference Negotiating Cross-Cultural Engagements in

nisso que eu te oriento. Ai está, há um ano que agente já vem conversando, tem que ter a licença, tem que ter a aprovação da Funai, tudo do modo sério, correto. E também, mostrar que a gente também quer dar um retorno para isso, que de repente a escola está interessada no material que a gente produzir, naquilo que a gente poder ajudar os índios, não é? Enfim, ai está, ele veio durante esse tempo todo, a comunidade que era o conselho anterior tinha gostado da proposta e a gente finalmente conseguiu a licença da Funai, demorou mas chegou, aí eu disse que agora a gente pode realmente começar o trabalho. Então, o Arqueólogo1 é o meu aluno de mestrado e a pesquisa dele é sobre isso, ele vai contar a história de ocupação de Lalima. E o Arqueólogo3 também é o meu aluno e ele também vai ajudar nesse trabalho só que o que ele vai fazer é um pouco justamente tentar ver qual é a visão que a comunidade tem dessa ocupação e do nosso trabalho, vai fazer um trabalho que vai ser, digamos, de reconhecimento dessas visões, desse jeito de perceber essas coisas. Ele vai conversar muito com as pessoas sobre isso, de como as pessoas 
Oceania", organizado por Robin Torrence e Anne Clarke (2000). A obra repensa o uso de categorias até então tradicionais, tais como aculturação, dominação e resistência, para trabalhar com categorias que permitem pontos de vistas duplos, como os processos de interação e negociação simbólica que perpassam, inclusive, aspectos da cultura material. Aspectos estes que podem refletir na cultura material momentos como: genocídio, doenças decorrentes do contato e até perdas de terras.

A pesquisa arqueológica desenvolvida em Lalima, apesar de não se referir exclusivamente a uma arqueologia do contato, possibilitou aos nossos interlocutores (graças ao aspecto etnográfico da pesquisa) o resgate mnemônico de eventos traumáticos decorrentes do contato. Memórias essas muitas vezes dolorosas, mas que inevitavelmente fazem parte não só da historiografia local, como, também, das formulações sobre jeitos de ser e origem das coisas. A história oral presente na fala dos anciões reflete essas considerações, nas quais os efeitos do contato com o branco se referem aos contextos culturais locais ou mesmo nacionais. Ou seja, o que encontramos nas entrelinhas das transcrições abaixo são os processos de elaboração de eventos traumáticos e a continuidade de elementos culturais refletidos no cotidiano.

\section{Arqueólogo3: E como chamava esse lugar?}

Ancião1: Pirizal... Ai que foi aumentando mais foi chegando mais gente... Foram trabalhando na comarca... Foram fazendo barraca... Foi chegando mais gente...

Arqueólogo3: Foi chegando de onde?

Ancião1: Ai do outro lado... Das fazendas... Vinham correndo pra cá [fugindo dos conflitos] ... Veio muita gente... Muita gente...

vêem o nosso trabalho e como elas percebem essa história de ocupação desse lugar. A gente espera que isso, que esse trabalho, essa história toda possa contribuir para que os jovens que vêm à escola conheçam essa história toda. Lalima é o resultado de tudo isso, tem uma antiga liderança, tem toda essa história que precisa ser preservada e que precisa ser contada e documentada. Então, esse é principalmente o nosso objetivo. E daí a gente tem que, a comunidade tem que saber se isso é importante, se é interessante, se a gente vai continuar o trabalho. Porque como eu disse para o Arqueólogo1, num primeiro momento, a gente vai de ficar dois a três meses aqui, trabalhando agora nesse projeto inicial, mas se tudo der certo, se for bom, se a comunidade gostar, se a gente entender que a gente está fazendo algo que seja útil para Lalima, a gente gostaria de ficar por mais tempo trabalhado aqui, ajudando a escola e em contato com a comunidade. Então, a nossa idéia inicial é que a gente vai começar a percorrer a aldeia e ver onde a gente encontra esses vestígios de cerâmica antiga que mostra as antigas ocupações. Conversar com os antigos moradores, documentar essas histórias antigas, como aquela que o Antigo ExCacique começou contar pra gente e, a partir disso, a gente faz uma reconstituição da história...

Liderança1: A senhora dá licença um pouquinho. Esse negócio de tapera velha onde moravam os nossos antepassados, a senhora quer dizer quando não era limitado? (quando a aldeia não era demarcada)

Arqueólogo2: Isso...

Liderrança1: Aqui nós também temos essa 
Esses dias eu estava contando e só dava umas treze ou quatorze famílias só que tinha... Mas, era só Kadiwéu, não tinha Terena --hoje já está misturado-não tinha Guaná, não tinha Kinikinau e origem de paraguai [guaranis]...

Nosso engenho de moer cana era pra lá... Feito de pau...era dois. Fazia rapadura, fazia açúcar da cana... Fazia bastante vendia pra Miranda... na aquele tempo era só trilheiro, não tinha estrada... era só trilha até Miranda.E os remédios daqui era só remédio do mato... aqui não tinha farmácia...

Ancião3: E aí como eu tava falando essa Fazenda Santa Rosa não era nem Santa Rosa era um retiro [Um ponto de descanso para as comitivas de gado] Aí então o que ele fez com o capitão Inocêncio, ele falou "Ô cacique, eu vou fazer um retiro aqui porque é muito longe para mim trabalhar o meu gado". Eles levavam uma semana viajando, naquele tempo era trilheiro, não era nem estrada. O cacique aceitou e também em troca disso cada semana tinha boi gordo para comer à vontade, para esses índios. Ai ficou, ele fez o retiro dessa fazenda, mas não era dele, mas como ele conseguiu convencer o cacique prometendo dar e de fato ele dava os bois. Então aí ele ficou, foi ficando... ficando... até que quando ele morreu o filho dele veio, que é esse que tentou matar o João Lima [figura histórica do banditismo pantaneiro.] , mas ele não levou sorte [o fazendeiro vizinho], logo depois o exército matou ele.

Arqueólogo3: Qual foi o primeiro cacique da aldeia?

Ancião2: Foi o Inocêncio, quando eu tinha uns três, quatro anos, saiu um baile violento no dia de Santo Antonio. Nós morávamos ai, nossa mãe nos colocou para dormir e fechou nós na casa e foi no baile. Clareou o dia procuramos a velharada, mas não

tapera que foi dos nossos antepassados, pra cá nós também temos na fazenda do Potrero (parte sul da aldeia lalima)... nessa da entrada, porque a minha mãe conhece tudinho ali. Só que minha mãe tá bem velhinha, mas ela lembra de tudo.

Arqueólogo1: $\mathrm{Na}$ verdade, todo esse projeto foi doado, foi concebido como projeto de um professor, em 2003, da UFMS. Ele veio aqui no encontro de educação indígena, acho que veio falar com os professores alguma coisa assim. Isso foi em 2003. E ai ele estava aqui dando uma volta pela aldeia e depois jogando futebol ele encontrou os fragmentos cerâmicos, fragmentos que eram, pertenciam a uma vasilha e foram feitos pelos índios que ocuparam toda essa região. E aqui nessa região do Pantanal, essa região de Mato Grosso do Sul, do Paraguai, essa região da serra, existem muita fontes históricas sobre os grupos indígenas, teve grupos que estavam aqui nos séculos XVI e XVII que foram instituídos pelos jesuítas nas missões, depois foram encomendados pelos espanhóis, aquela história da encomenda que os espanhóis faziam na troca de escravo, depois os bandeirantes vieram para cá, para a região, e começaram a atacar as missões jesuítas, os grupos indígenas, e depois vieram outros grupos para cá. Os grupos do chaco: Mundukurú, Guaná, os Terena, os Kinikinau, os Laiana e eles vieram do chaco para cá em grande fluxo migratório nos séculos XVII, XVIII.

E a gente acredita que os vestígios de toda essa movimentação e tal, foram deixados por toda essa região, a gente tem vestígios arqueológicos, por exemplo, em Corumbá, 
estavam ...tava tudo no baile. Ai, arrombamos a porta e fomos lá, mas quando chegamos lá só tinha gente morta. Foi o capataz da fazenda...mataram o meu cunhado, a irmã do meu cunhado, mas o capataz morreu também. Laurindo Buarque era o fazendeiro.

Tal perspectiva etnográfica e arqueológica permite repensar teorias sobre o contato, especialmente aquelas que trabalham com noções totalizadoras de aculturação, poder e dominação (THOMAS, 1994), sem desconsiderar os efeitos de uma guerra ou conflitos armados. Sobre esses efeitos é importante lembrarmos o trabalho de Eremites de Oliveira \& Marques Pereira:

“É consenso entre historiadores e antropólogos que a guerra entre o Paraguai e a Tríplice Aliança representou um profundo golpe para as formações sociais das populações Guaná-Chané. O principal transtorno provocado pela guerra foi a destruição das grandes aldeias e a conseqüente desterritorialização da maior parte da população que nelas vivia.

Esta situação impôs sérias limitações à produção da vida material e ao exercício de formas de sociabilidade. Entretanto, os efeitos da guerra teriam sido mais traumáticos se os indígenas não pudessem contar, naquele momento, com o apoio que receberam da população das pequenas aldeias, transformadas em aldeias refúgios, principalmente para mulheres, crianças, velhos e doentes."

(Oliveira \& Pereira, 2007, p 01.)

tem vários tipos de cerâmica: cerâmica guarani, cerâmica guará, cerâmica guaicuru, outros tipos de cerâmica que a gente nem sabe que índio que fez, pedaços antigos... A gente acha que todas essas movimentações foram deixando vestígios dos antigos assentamentos desses grupos e, a partir desses vestígios, a gente vai tentar comparar com a história, pra ver se a gente pode contar também, por conta desses vestígios arqueológicos, toda essa história da ocupação indígena do Mato Grosso do Sul, sobretudo da região do Pantanal. É nesse sentido que a Aldeia Lalima é interessante porque ela é uma aldeia multiétnica. Ela coloca vários grupos, vocês oficialmente são Terena, mas a gente sabe que tem aqui vários grupos e é bem interessante para se pensar sobre os vestígios já que a gente acha que poderemos encontrar vestígios de todos esses grupos. Basicamente esse é o trabalho que a gente vai tentar fazer. E como a gente vai trabalhar? Nesse primeiro mês, nós três vamos estar aqui, nos primeiros 20 dias a gente vai ficar andando e procurando pelas fazendas, pelos quintais das casas, nas beiras dos córregos e em outros lugares para ver se a gente encontra esse material cerâmico e aí a gente vai registrar esses lugares e depois vem um rapaz que vai fazer um mapeamento de todas essas áreas. Vai mapear tudo, e depois a gente passa para coleta. A gente vai coletar o material, a gente vai levar para o laboratório, analisar, a gente vai estudar todas as decorações, todas as alterações, como são as formas. A gente acredita que vai poder reconstituir alguns vasos quebrados. Depois disso, a gente vai também procurar pela escavação, porque muitas vezes, como passou 
Assim, podemos ver refletida também nas falas dos anciões a rede social a qual se encaixava a aldeia Lalima na Guerra do Paraguai, o seu caráter de refúgio indígena e a longa relação social desenvolvida com os Kadiwéu, presente em inúmeros relatos de campo.

Ancião2: Ele [o avô] nasceu lá na aldeia kadiwéu. Ele correu de lá para cá.

Arqueólogo3: Por que ele corre?

Ancião2: Correu porque não queria morrer.

Arqueólogo3: Ah! Porque estava em guerra!?

Ancião2: É

Ancião1: Eles se reuniram aqui e não correram mais. Eram bem armados, eram guerreiros tinham até armas de guerra, mosquetão, carabina 44.

(...)

Arqueólogo3: E o que tem lá na Toca da Onça, que o senhor estava me contando ontem?

Ancião1: Lá era acampamento desses guerreiro mesmo. Cruzou muito gado aqui, atravessando dali.

Arqueólogo3: Acampamento guerreiro da onde? Os Kadiwéu?

Ancião1: É. Esses índios mesmo que viam escondidos, eles eram poucos e os paraguaios eram muitos, eles matavam de 'atração'.

Arqueólogo3: O que é matar de 'atração'?

Ancião1: É matar sem ele vê.

Arqueólogo3: Ah, eles escondiam depois atacavam!?

muito tempo, às vezes tem uns 500 anos, 1000 , 5000 anos, pode ser. Como passou muito tempo, com o vento, com as outras ocupações que vão chegando, as vezes, o material fica assim a $20 \mathrm{~cm}, 30 \mathrm{~cm}$. Aí a gente tem que fazer essas escavações arqueológicas, a gente tem uma série de métodos e técnicas e tal para tentar encontrar o material. Ás vezes escavando que a gente percebe toda essa sucessão, todo esse movimento, porque os materiais são diferentes, às vezes um fica em cima do outro.

Nesse primeiro mês vamos ficar nós três e no próximo, eles vão, e depois vem duas pessoas para auxiliar lá de São Paulo e até conversamos que teremos mais duas pessoas aqui da comunidade nesses primeiros 20 dias. E logo vamos começar o serviço de coleta, ai a gente vai trabalhar, ai vamos chamar mais três pessoas.

Arqueólogo2: $\mathrm{Na}$ verdade, o nosso objetivo é mesmo tentar fazer uma história grande da ocupação, como é que a aldeia chegou a ser dessa maneira, sua história até hoje, e também é muito complicado isso o que o Arqueólogo1 está propondo... como isso vai acontecer não dá para vocês saberem muito bem, a idéia é a de que quando isso começar a acontecer, se vocês quiserem nos visitar durante os trabalhos, ficar conversando, vendo, querendo que a gente mostre. Aí eu acho que isso tudo fica mais claro, mais fácil de perceber como é que é.

Arqueólogo3: Na verdade, eu acho que isso é fundamental, não deixem de perguntar sobre o trabalho que a gente faz, é importante até para a gente entender como que a gente trabalha com vocês. 
Ancião1: É. A estrada deles [dos paraguaios] era ali e enquanto eles não apareciam eles [os Kadiwéu] não saiam dali. Ali eles passavam sede e fome, sol e chuva e tava ali. Passava e ficava um pouco.

Arqueólogo3: E onde mais eles ficavam?

Ancião1: Aqui no caminho desse porto, era um porto velho, tinha balsa que ia até embaixo, acamparam no campo aqui na área também, aqui ficavam esperando o adversário, dentro do mato.

Portanto, é possível inferir sobre a relação entre identidade étnica e contextos etnohistóricos. O caráter de refúgio da aldeia, os conflitos constantes com fazendeiros vizinhos e os aspectos interétnicos apresentam-se como marcadores temporais (e de identidade) muitas vezes articulados com a cultura material. No entanto, tal articulação não é evidente em uma abordagem direta, característica de uma lógica científica de pergunta-resposta. Ela está nas entrelinhas discursivas e nos efeitos catalisadores mnemônicos acionados no contato entre o arqueólogo, o vestígio arqueológico (objeto) e o índio.

Arqueólogo3: Esses cacos ai, que acha ai na terra?

Ancião1: Isso faz tempo que eles andavam ai... correndo da revolta, morando em qualquer parte. Jogava em qualquer parte... Pra cá tem uma baia ai embaixo... lá no laranjal, naquelas casas lá, era ali que eles moravam ... Chama baia do laranjal...

Arqueólogo3: Ah, os paraguaios... Moravam paraguaios lá?

Ancião1 e Ancião2: Não... era nos índios, escondido dos paraguaios.

Arqueólogo3: E que tipo de índio?

Arqueólogo1: O que a gente pode falar sobre esse projeto aqui é que a gente está há mais de um ano tentando. Todo o trabalho aqui, tudo dentro do legal, dentro da lei, com todos os trâmites e todos os procedimentos com a Funai. A gente conseguiu outras licenças que a gente tem para trabalhar e coletar material de outras instituições e a gente veio para cá com o apoio da nossa universidade, a Universidade de São Paulo, e as pessoas que trabalharem com a gente vão ganhar certificado falando quantas horas trabalhou, capacitando elas a trabalhar em outros sítios arqueológicos no futuro.

Arqueólogo2: Estamos preocupados também em capacitar os professores que quiserem ficar com a gente. Temos a possibilidade de trazer quadros, de trazer livros, de trazer seriados, a gente sabe que a escola está sempre carente desse tipo de coisa, de apoio, de alimentação, de acompanhamento, então na verdade isso é uma coisa que é muito tranqüila para a gente ajudar a fazer. Eu estou disposta a trabalhar com isso, eu trabalho com isso há muito tempo, com professores indígenas. $\mathrm{O}$ que eu acho muito bom em Lalima, e que não acontece em outros lugares, é que aqui os professores são da comunidade. E isso é uma coisa muito rica, tem gente porque, às vezes, na grande maioria das escolas indígenas, ainda são brancos que dão aula para as populações indígenas, aqui pelo menos já tem essa iniciativa mesmo e eu acho isso uma coisa muito importante. E assim, eu tenho a maior disposição e boa vontade em ajudar esses professores e essa escola que é fundamental e eu sei que isso é muito caro e que normalmente isso é uma carência porque 
Ancião2: Kadiweu, mesmo... Morava lá na tapera do laranjal... Fica meio retirado do rio... Perto de um lagoão... Curicho do Laranjal ...

Arqueólogo3: Morava gente lá?

Ancião1: Não...Os índios se escondiam lá dos paraguaios...amoitado (...)

Arqueólogo3: E lá no laranjal, fazia pote também?

Ancião2: Não, eu passei uma vez, ali caçando. O meu primo me mostrou, era formado, só pé-de-laranja. Procurei com ele se tinha morador lá, mas não. Eram os corridos da guerra dos paraguaios com os Kadiweu. Foi ai que apareceu o meu pai, o meu pai era Kadiweu a minha mãe Kinikinau, nem existe mais.(...)

Arqueólogo3: Seu avô também?

Ancião2: Era corrido também, mas ele era jagunço... Veio matando muito paraguaio.

È a dinâmica de interação em torno da cultura material mobilizada pelo arqueólogo que suscita a apropriação, a elaboração e a explicitação dos possíveis significados êmicos. Esses significados, todavia, podem não ter relevância direta para um arqueólogo tradicional, já que a desconsideração com a memória do outro se torna evidente e é característica de um vertente colonialista da arqueologia.

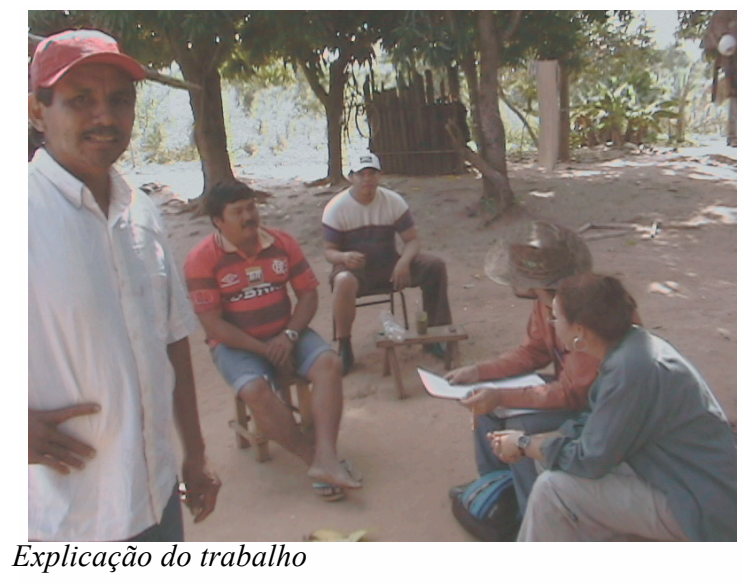

\section{Explicitação da Pesquisa}

Posto esse breve contexto etnográfico, tomo como fio condutor seguinte a análise da reunião dos arqueólogos com o conselho das lideranças de Lalima que foi feita antes do início do trabalho de campo arqueológico propriamente dito. Essa reunião foi o primeiro momento de apresentação da equipe, no entanto, o contato e a proposta de pesquisa já vinham sendo explanadas junto aos índios de Lalima cerca de um ano antes pelo arqueólogo responsável (Arqueólogo1). Esta cena

como o antigo ex-cacique estava falando, a Funai cada vez mais está sem recursos e a gente sabe que isso é no território nacional inteiro e não é só no Mato Grosso do Sul. A gente vê isso até mesmo na Amazônia, que os índios estão lá no meio do mato, isolados, mesmo lá a Funai tem uma carência de auxílio e cada vez mais, na verdade, as populações indígenas estão tendo que buscar recursos e apoios e orientação de outras formas, o papel da universidade eu acho que também é esse. A gente que trabalha com populações indígenas na universidade, eu acho que a obrigação da gente, como professores da universidade, também é essa, essa é a minha vontade. Não é fazer um trabalho no qual eu não consiga dar um retorno para a comunidade que eu trabalho, isso não faz sentido para mim. Então, se um dia a comunidade achar que não interessa mais, a gente não faz. Porque eu só trabalho onde eu sou bem vinda e onde eu sei que o meu trabalho contribui para alguma coisa.

Liderança3: Em quantas áreas vocês já 
etnográfica é um dos elementos articuladores para o diálogo e reflexibilidade que as outras cenas sugerem.

Em linhas gerais, são raros os momentos em que conseguimos comparar uma interlocução entre pesquisadores ou uma interlocução de pesquisadores com grupos indígenas. É interessante comparar como a dinâmica de explicação é diferenciada entre o começo da reunião com o conselho e com a que segue, o diálogo entre cientistas (ANEXO 1). A diferença se dá não somente nos diferentes âmbitos de compreensão, mas também nos objetivos apresentados da pesquisa.

Esse esforço científico de racionalização implica no uso de um vocabulário muito restrito ao círculo acadêmico. Como, por exemplo, todo o meu arqueologuês e antropologuês implicam em um sistema de diálogo de difícil compreensão por parte do outro. Em campo, mobilizamos todo um léxico científico que não é evidente (nem sempre) para o outro que não é arqueólogo e vice-versa. Dessa perspectiva, resta a reflexão de até que ponto o discurso científico permanece fechado em si? E de fato, estabelecer uma interlocução com o outro de forma simétrica nem sempre é possível, por mais consciência que se tenha dos processos discursivos, mas assumir a atitude desse olhar coloca no horizonte a simetria das relações em pesquisas futuras. Postura essa que pode ser elaborada teoricamente (e/ou metodologicamente) como multivocalidade.

Essa multivocalidade pode ser entendida como um espaço criado para múltiplas vozes na interpretação sobre o passado que, claro, acaba por implicar uma tensão sobre o discurso reconhecido e legitimado pelo pesquisador. Segundo autores como Kojan \& Angelo, as implicações da multivocalidade vão além de um debate teórico:

fizeram trabalho?

Arqueólogo2: O Arqueólogo1 começou agora porque ele é aluno de mestrado. E ele na verdade está começando a fazer esse trabalho agora, o primeiro trabalho dele, mas eu já trabalhei em área Kaiapó, já trabalhei em área Assurini, já trabalhei em área Kaingang.

Liderança3: Então a senhora, com certeza, tem algum documento dos trabalhos da senhora lá para mostrar para a gente.

Arqueólogo2: Eu não trouxe nada do meu trabalho, mas eu posso trazer...

Liderança3: Porque a senhora sabe que hoje em dia, nessa região, nós somos índios moradores daqui, a gente perdeu muito para esses brancos em volta. Porque hoje em dia, a senhora sabe, se não for através de documento ninguém faz nada, então a pergunta que eu queria fazer para a senhora é: tem pelo menos algum documento que vocês trouxeram? Arqueólogo 1: Sim. O Chefe de Posto nos acompanhou, nós temos todos os documentos autorizando o nosso trabalho.

Liderança3: Porque como o senhor está falando que vai trabalhar honestamente numa hora dessas, todos nós da aldeia, temos que explicar a presença de vocês. Inclusive aqueles que não estão aqui, no conselho.

Arqueólogo2: A gente já providenciou, a gente jamais iria trabalhar na aldeia sem a licença, tendo que trabalhar em área indígena com a licença da Funai; a Funai me reconhece, eu tenho uma boa relação com a Funai de Brasília. Eu trabalho há mais de dez anos em área indígena eu também tive essa preocupação, o documento está aqui, eu não viria se não tivesse saído. Então porque eu também gosto de trabalhar na confiança 
"multivocality should not be seen as a theoretical perpective to be adopted or discarted according to one's theoretical proclitivities, but is closer to truism historiography.(...) multivocality in archaeologhy cannot be simply understood as a diversity of voices, but rather needs to be undertaken as part of a larger project of interrogating and discussing the contemporary uses of the past and, primarily, acknowledging accountability with a past that is inextricably tied to a present." (Kojan \& Ângelo, 2005:397)

Portanto, a interlocução de saberes qualifica a natureza da relação que se estabelece com o outro.

“Arqeuólogo2: É, tem tudo a ver. Está tudo fechando, as coisas estão casando. E sem contar que metodologicamente estamos fazendo todo o trabalho de arqueologia em terra indígena, que é literalmente fazer arqueologia em área indígena. Que envolve todo o processo de interlocução, de todo dia ouvir o que os índios têm a dizer. Isso tem que fazer parte da metodologia de trabalho, isso te atrasa e adianta ao mesmo tempo. Ficamos oscilando neste processo todo. "(ANEXO1)

Assim, em termos simétricos, quando o Arqueólogo1 chama para si o seguinte enunciado: “... é conversando que a gente se entende.", ele põe em jogo as negociações de significados exigidas em torno da pesquisa. A negociação de conhecimento revela tensões existentes sobre os detentores de saberes, seja este acadêmico (arqueólogos) ou tradicional (a comunidade indígena), passível de um viés

mesmo porque se não tiver isso acho que fica difícil. Então, a gente trouxe as cópias dos documentos porque é uma preocupação que eu tenho. Eu acho que a gente deve trabalhar em comunidades indígenas quando está tudo legal, quando a Funai aceita que esse trabalho seja realizado.

Liderança 3: Só para terminar a minha fala, está certo isso o que vocês estão falando. Daqui a cinco, seis e sete anos o que vocês estão dizendo já sumiu, mas, com certeza, vocês devem trazer um aparelho para provar que tem alguma coisa por aí ou não?

Arqueólogo1: Não, mas a gente usa um aparelho chamado GPS. Ele serve para dar as coordenadas geográficas do lugar que estamos procurando pelas informações que a gente vai coletar com vocês, procurando pelo chão para ver se encontra. Existem alguns outros aparelhos, que você passa por cima da terra chamado GPR, que mostram o que tem em baixo da terra, só que a gente não tem esse aparelho, esses a gente não usa.

Liderança1: Eu não sei se todos concordam ou não, mas eu não concordo em usar esse aparelho não.

Arqueólogo1: As ferramentas que a gente usa são: marreta, enxadão, a enxada, às vezes, um facão. Para mostrar para vocês... Isso aqui é a colher do arqueólogo, que é a colher de pedreiro um pouco menor. A gente tem o maior cuidado com esse material, a gente considera esse material arqueológico como patrimônio histórico do Brasil, então a gente vai ter o maior cuidado com ele, vai coletar, tirar todos os dados de onde foi coletado, colocar em saquinho com etiqueta com todas as informações e aí a gente vai escavar com a 
político: "(..) defender aquilo que é melhor para a toda nossa sociedade da aldeia Lalima. (Cacique)", pondo em tensão a idéia de o que é bom para a aldeia não é necessariamente bom para o cientista e vice-versa.

Portanto, esse aspecto relacional da pesquisa - a multivocalidade - leva em consideração aqueles que não costumam ser ouvidos no mainstrean acadêmico. Não apenas para outras interpretações sobre o passado, mas também sobre a influência que outras vozes exercem sobre uma pesquisa realizada no presente.

Esta perspectiva, por sua vez, influi sobre a idéia comum de preservação em arqueologia (LIMA, 2007), encontrada na discursividade do arqueólogo1:

Arqueólogo1"... ajudar essas populações a conseguir se manter na sua identidade, na sua história, preservar essas coisas todas, preservar seus direitos sobre as suas terras, tudo isso é ao mesmo tempo ter uma vida digna também, ser reconhecido..." Lógica esta, enfim, que se mostra semelhante aos termos das representações que são colocadas em jogo na negociação de poder e de sentidos não só descritas acima, mas, também em outros momentos da pesquisa. Como, por exemplo, a tomada de posição aversiva aos arqueólogos que pesquisavam no seu quintal, demonstrada por uma moradora da comunidade.

Arqueólogo2: Eu tentei falar com ela... mas ela estava muito agressiva... ela não quer, ela não tem interesse, ela não quer nem saber!

...que ela não foi avisada pelo cacique e não importa o que eu disser que ela não vai deixar (pesquisarmos) que essa aqui é a plantação dela...ela acha que tem que ser preservada (os vestígios de cacos cerâmicos) e que ninguém pode pegar nada...eu

colherzinha. Assim, o pessoal até brinca com a gente às vezes, porque a gente fica cinco, dez, vinte anos estudando os grupos indígenas só que fica fazendo buraco com o pincel. A gente não vai trabalhar com nenhum aparelho eletromagnético, geofísico ou alguma coisa assim que possa sondar o que tem embaixo, o que a gente vai fazer é andar pela aldeia. Eu com uma pessoa da comunidade e o Arqueólogo 2 com outra. A gente faz mapas, como a gente vai esclarecer agora, a gente vai andando, procurando as coisas pelo chão e conversando com as pessoas...

Arqueólogo2: $\mathrm{O}$ importante, na verdade, é que nós ficaremos abertos para a comunidade. Nada vai ser feito sem a comunidade saber. Sempre vai ter alguém (junto ao trabalho), nada vai ser feito sem a comunidade saber.
Liderança2: Esses trabalhos todos, que a gente está participando, eu sempre pensei, que a antropologia para nós aqui, porque essa nossa área precisa de um antropólogo, todo mundo sabe, porque é uma área que está em questão de demarcação ainda em andamento. E a gente sempre imaginou que um dia nós pudéssemos arrumar um antropólogo para morar junto com a gente, como fez Darcy Ribeiro, que foi uma pessoa que foi muito boa para os índios e ele tinha conhecimento profundo dos índios e ajudou muito. Que fosse uma pessoa com muita confiança. Porque área indígena são áreas complicadas. São perícias entre os fazendeiros e o índio. A gente sabe que são perícias. Aí tem que tomar muito cuidado. Todo mundo sabe que é uma área indígena, e, como a nossa área, é 
disse então, que a senhora conversa com o cacique que ele vai lhe explicar... (Anexo3) Por se tratar de território indígena, essa situação resulta em uma complexa negociação de sentidos e representações, justamente pela possibilidade de criação de identidade (e alteridades) junto a materiais arqueológicos que podem tomar um caráter de reivindicação hereditária (JONES,

1997). Casos como esses podem ser verificados no noroeste Argentino, junto aos índios Quilmes, com a retomada de um importante sítio arqueológico: a 'ruina de los quilmes' passa a ser 'ciudad sagrada quilmes' (MARCHEGIANI et al, 2007) ; ou mesmo nos EUA, como demonstra o livro Skull Wars (2000) de David Hurst Thomas, sobre a polêmica do "homem de Kennewick", considerado um dos mais antigos vestígios de ocupação humana nas Américas.

No entanto, apesar dessas expressões mundiais, no Brasil ainda é incipiente um movimento, político ou acadêmico, de questionamento indígena em torno de vestígios arqueológicos, com a exceção de alguns manifestos que discutiremos mais adiante.

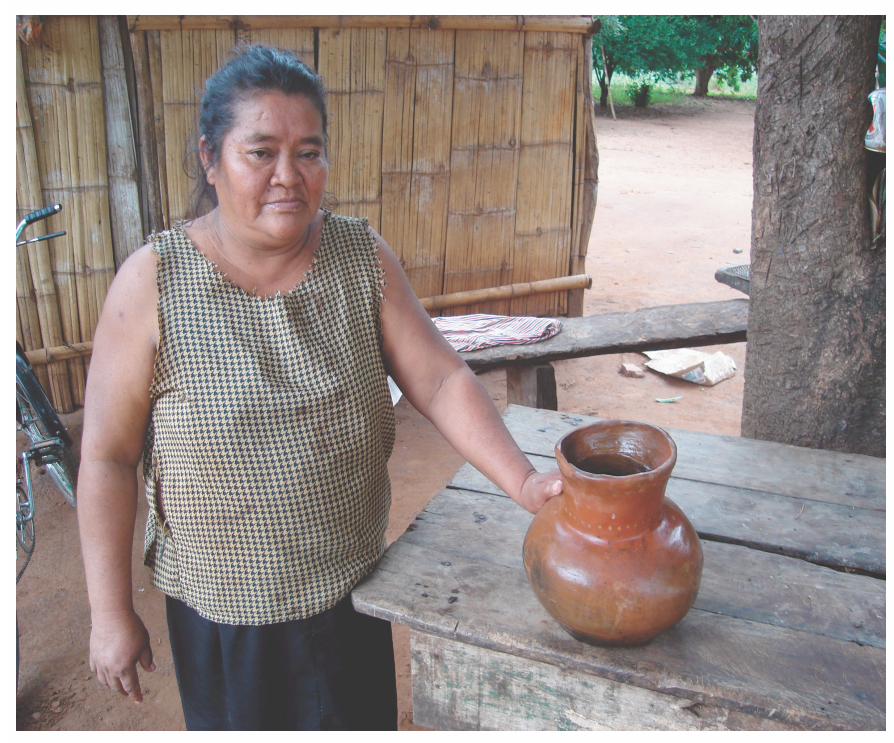

Cerâmica Terena

\section{Dinâmica política interna}

Logo na primeira fala do cacique, referente a reunião com o conselho indígena, temos uma afirmação da legitimidade do conselho, com a finalidade de explicitar não só para nós, arqueólogos, mas também às lideranças, a sua autoridade e posicionamento políticos. Nós pudemos compreender essesentido político na dinâmica cotidiana do trabalho, nos almoços com algumas famílias e na interação com a comunidade. Uma situação que se revelou emblemática, logo no começo do campo, foi aquela quando fomos cumprimentar uma família influente em outro setor da aldeia - família esta que possibilitou os primeiro contatos para a pesquisa em Lalima. Para a nossa surpresa, descobrimos que essa família tinha estabelecido um conselho indígena dissidente, o conselho do Setor da Campina, que gerou uma disputa de legitimidade de representação entre a comunidade e

complicada! Essa área aqui ainda não está definida, nós estamos lutando... Eu digo isso por que a antropóloga da Funai fez o trabalho e não deu em nada, pegou a nossa confiança, nós mostramos toda área para ela, para o trabalho de demarcação.

Arqueólogo2: Quem é?

Liderança2: X. Diz ela que é antropóloga de Brasília. Então a gente fica com medo né, porque se trata, por exemplo, da nossa questão econômica... Porque ao invés da gente estar ajudando o trabalho pra comunidade, a gente tá ajudando os de fora (os fazendeiros). A gente está fazendo uma pergunta que é a seguinte. A gente gostaria sim, de uma antropóloga muito bem conceituada e de confiança na nossa comunidade para ajudar nesta nossa causa indigenista que tem muitos anos. Vai saber quantos anos mais... De lá para cá, a causa nunca foi resolvida. Eu acho que a ocupação aqui foi dos índios Guaicurus e Kadiwéus, todo mundo sabe, então eu faço essa pergunta: como esse trabalho dos senhores e da senhora vai chegar? É apenas para conhecer a história dos índios, ou vai ser apenas para formar um livro? Ou vai ser 
a Funai. Essa cisão política é confirmada na fala do cacique, transcrita abaixo (ANEXO2), logo após a reunião do conselho, que enquanto nos posicionávamos frente a esta questão o convidávamos a nos acompanhar no Setor da Campina.

Cacique: O companheiro ali (uma outra liderança) não acha por bem (eu) fazer presença com eles (conselho da Campina), porque senão vai dar mais força pra eles, na qual eles querem. Porque lá, não está todo o povo daquele lado (setor da Campina), mas isso não impede de vocês ficarem falando (de irem lá)...

Não é foco desta pesquisa se aprofundar nas dinâmicas políticas internas da aldeia, todavia almejamos entender como essa dimensão influencia na prática de execução do projeto de pesquisa arqueológica. Assim, na investigação arqueológica, essa tensão entre setores joga com o primeiro impulso científico de estabelecer um interlocutor oficial, 'o informante' - clássica figura antropológica geradora de tanta discórdia e teses de doutorado. Este agente coloca em xeque o preparo de atuação para uma escavação, já que a validação desse interlocutor pela comunidade pode não acontecer. Essa implicação logística força um reposicionamento do arqueólogo. Dentre os processos científicos envolvidos nesse reposicionamento, estão tanto a apreensão do que pode vir a ocorrer quanto a construção de cenários por parte dos pesquisadores. O exercício de construção de cenários suscita estratégias de aproximação junto à comunidade local e dinamiza cotidianamente as estratégias de pesquisa. Nesse sentido, começa a se configurar o intuito de mapear as redes de relações de poder na comunidade, com a clara intenção de se evitar conflitos com a equipe de pesquisa. $E$, de forma simétrica, é nesse momento que se afirmam e se explicitam as relações de poder entre os pesquisadores, justamente para evitar conflitos com a rede de poder local e para se estabelecer, no ponto de vista do coordenador, a coesão do discurso no trabalho arqueológico.

apenas para acabar com esse preconceito, entre o branco e o índio? Porque eu acho que existe preconceito entre nós e o branco, é isso que eu gostaria de saber, se esse trabalho é um livro ou vai ser apenas para a universidade ficar com uma prova: "Os índios são assim, assim e assim". E nós por outro lado não ganhamos nada, porque é a vontade de Brasília, eu já tenho 60 anos e até hoje não tem solução. Chega um antropólogo, um aluno de Brasília, um aluno de São Paulo, de várias partes, mas na hora de estudar a área de demarcação dos índios, ela não acontece... Porque o pesquisador vai lá, conhece o fazendeiro, vai na casa dos fazendeiros, o fazendeiro dá dinheiro e o que acontece, nasce o doutorado. Porque quem tem dinheiro tem justiça e nós que não temos. Nós precisávamos desse antropólogo, para ajudar a gente a requerer esse pedaço, eu acho que aí sim.

Nós gostaríamos, eu gostaria, tanto que eu vou conversar com vários caciques para que tivéssemos esse antropólogo aqui morando conosco, para estudar a nossa natureza. Felizmente a natureza nossa não é como aquele que o branco vê lá de fora - 'os índios lá de Lalima já perderam o idioma, já não são mais índios, então vamos invadir...' eles falam assim - mas não é isso! A gente precisa dessa pessoa de confiança para reforçar a nossa tradição que ainda existe aqui dentro. $\mathrm{O}$ nosso Chefe de Posto é índio, filho daqui, criado aqui na aldeia, mas isso veio depois de muitos anos...

Então a gente queria que essa pessoa andasse por esse caminho e não apenas para estudar, levar e guardar lá. O nosso interesse aqui é o que? Preservar. Como estávamos falando do 
"Arqueólogo2: Então, o Arqueólogo1 é o meu aluno de mestrado e a pesquisa dele é sobre isso, ele vai contar a história de ocupação de Lalima. E o Arqueólogo3 também é o meu aluno e ele também vai ajudar nesse trabalho só que o que ele vai fazer é um pouco justamente tentar ver qual é a visão que a comunidade tem dessa ocupação e do nosso trabalho, vai fazer um trabalho que vai ser, digamos, de reconhecimento dessas visões, desse jeito de perceber essas coisas."

É nesse momento, também, que o coordenador é responsável pelas negociações políticas e administrativas da tomada de decisão final. O aspecto da explicitação da hierarquia entre pesquisadores está presente inclusive em outros contextos do trabalho arqueológico, como a "arqueologia de contrato", a arqueologia feita em termos empresariais e os famigerados relatórios de Impacto Ambiental, entre outros.No dia-a-dia do campo, esse esquema hierárquico sofre constantemente tensões decorrentes de pequenos privilégios na logística de campo, da interação com os informantes ou até mesmo da falta de reconhecimento de autoridade perante o arqueólogo sênior. Tais tensões acabam por influir em duas principais percepções reflexivas do arqueólogo em campo, baseadas na perspectiva do ensino de geração sobre geração, a respeito do métier arqueológico. Uma é a percepção de competência profissional, do que é preciso para satisfazer o supervisor e 'ser' um arqueólogo. Outra é a competência social, do que é preciso para ser reconhecido entre seus colegas como companheiro de confiança (HOLTORF, 2006).

No caso, a tensão decorrente dos conflitos políticos internos de Lalima foi resolvida, principalmente, com a contratação de auxiliares de campo dos dois setores de

caso dos professores índios, que a escola recebesse nossa tradição dentro da sala de aula. Nós estamos no meio de perguntar, de explicar porque muitas vezes a senhora chega inocentemente sem saber o que é que nós estamos passando.

Arqueólogo2: Realmente isso é muito importante.

Liderança2: Então nós já estamos dessa forma, cansados e cansados de tudo que é promessa e não acontece nada. Eu já estou quase que voltando pra trás (morrendo) e será que meus filhos vão ficar nesse mesmo caminho!? Nesta mesma terra, porque os meus pais já morreram, lutaram e lutaram pela demarcação da terra, também meus avós e até hoje não aconteceu. Então eu passo esse esclarecimento, ele (o Arqueólogo1) está certo, ele está estudando, mas a senhora tem mais conhecimento porque é antropóloga. Não faz um trabalho ruim, já fez vários trabalhos com várias aldeias. Eu até gostaria do seguinte, que apresentasse um vídeo, eu tenho certeza que tem. Você possui um vídeo desses trabalhos? Arqueólogo2: Vídeo não, tenho foto...

Liderança2: Traga pra nós ( e diga:) 'esse foi meu trabalho'. Mas, é muito interessante a proposta para nós, porque vamos saber de tudo que existe naqueles materiais, vai ser estudado há quantos séculos essa terra é da gente, e quais foram os índios mesmos daqui, porque agora misturou tudo. Tem Terena, Kinikinau, Laiana os Guaicurus que é uma família grande que mora aqui em cima, que nem esse aqui (ele aponta para Liderança4) que é legítimo. Ele é diferente de cada um, pode olhar. O pai dele a mãe dele os avós dele são todos Guaicurus. Só que perderam o 
representação política da aldeia. Assim, observando essa tensão política, passamos para os dois caciques a decisão da escolha desses auxiliares que, por se tratar de atividade remunerada, gerou mais polêmica entre os setores (Sede e Setor da Campina) e a comunidade. Ao mesmo tempo, lembrando o dispositivo de poder de Foucault(2004) --caracterizado como ato/atividade de pensamento, à ordem reificada e reificante de um sistema social-- acabamos por reconhecer a outra liderança local, já que forçamos o diálogo entre os dois caciques para a indicação dos auxiliares de campo, além de termos atuado como mediadores entre os dois setores.

\section{Marcadores de assimetria}

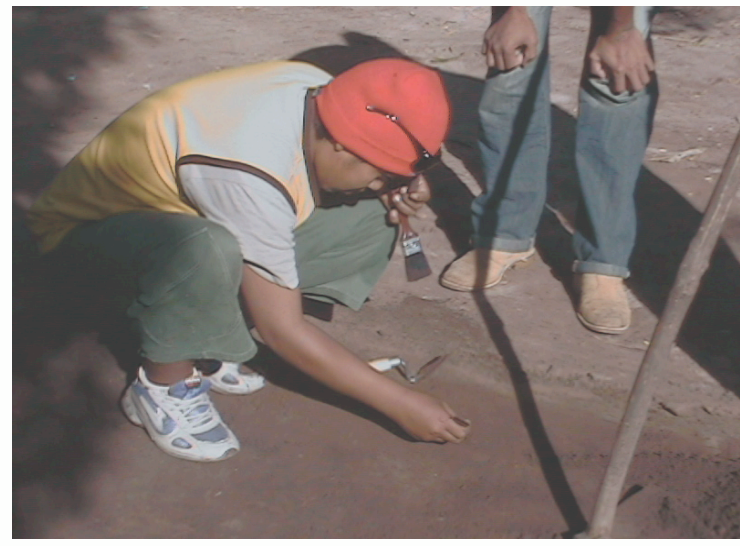

È fato conhecido que as populações indígenas sofreram com a situação de contato e esboçam as relações de opressão as quais foram impostas. Isso aparece em fragmentos discursivos no cotidiano indígena e na interação com os não-índios ainda hoje, reificando a forma opressiva. Assim, encontramos durante o campo alguns exemplos que marcam a relação

Criança terena brinca de escavar assimétrica, inclusive de forma invertida

(anti-opressiva).

Exemplo 1) Antigo Ex-Cacique : Aqui nós somos diferentes... ninguém fala (na língua Terena), e vamos falar que somos índios? E a língua portuguesa, não sabemos se falamos um dialeto ou português...

Quando se coloca em jogo a classificação de uma língua como idioma em contraposição a um dialeto, o interlocutor está questionando a validade da própria forma de se comunicar. Existe consenso entre os socioliguistas (CESAR \&

idioma, acho que é porque está tudo misturado e não conseguiram mais falar. Então é isso que queria passar para vocês

Arqueólogo2: Eu posso dizer uma coisa, eu tenho 42 anos e eu comecei a fazer antropologia eu tinha 22 , então eu estou 20 anos fazendo antropologia e o que o senhor está me dizendo de frustração por causa do trabalho indígena, por causa das promessas, e as coisas não se cumprem, eu também tenho muitas frustrações, porque na verdade a gente escolhe ser antropólogo porque a gente quer que a cultura indígena seja preservada, a gente não só quer conhecer mas a gente quer que o modo de vida continue, porque me dói muito como eu já vi em muitos lugares as crianças que já não sabem mais falar a sua língua, ou então ver os jovens que são adolescentes, que estão muito mais preocupados em sair da sua aldeia e virar brancos do que continuar preservando porque eles acham que o modo de vida indígena já não serve mais para eles, que isso é coisa dos velhos. Então a minha preocupação eu nem sei se é certa, mas é que quando eu converso com os meus amigos índios, eles sempre me dizem "tem que continuar registrando o que a gente faz, tem que continuar guardando o que agente faz, tem que continuar trabalhando porque o jovem tem que entender que ser índio, a gente tem que ter orgulho disso, e que preservar a terra da gente depende disso" e eu sempre falo 
CAVALCANTI 2007) que o termo dialeto é para referir variantes de uma mesma língua, nunca outra língua. O que ocorrer é o seguinte: Chamamos de variante a variedade de uma língua falada por determinada parte da população. Essa variedade vai valer o que vale o seu falante, ou seja, a variedade de quem freqüentou a escola vai valer mais do que a variedade de quem não freqüentou a escola, assim como o salário dessa pessoa. A variedade de um nativo vai valer mais do que a variedade de um imigrante ou mesmo de um migrante, se pensar em termos regionais. Então, historicamente ficou decidido que a variante que vale mais é aquela dominada pelos cidadãos de maior prestígio, sobretudo econômico. Essa variedade é chamada de variedade padrão ou norma padrão ou mais precisamente ainda norma culta (que pode ser tanto falada quanto escrita). As demais são tomadas como dialeto de variedade padrão. Hoje em dia, a variedade falada padrão é próxima ao português falado pela Rede Globo. O ensino de português feito nas escolas do Brasil tenta ensinar essa variedade para as crianças com o discurso de que a variedade delas é errada. Essa noção de que pessoas "comuns" não sabem falar o português corretamente é corrente na sociedade. É uma estratégia mesmo para estigmatizar as pessoas. Quando o cacique Terena diz que não fala Terena e não sabe se fala português ou um dialeto, isso mostra que:

- ele está reproduzindo um discurso fartamente ouvido de que esses índios falam tão errado o português que não dá nem pra entender, portanto, não é língua, é dialeto; cientificamente, um dialeto é igual a outro dialeto.

- só é índio quem fala língua indígena, então se ele não fala mais a língua indígena e não fala nem o português, o que será dele???

para os jovens isso.

Liderança2: Eu também...

Arquólogo2: Que eles têm que saber, que eles têm que continuar preservando as suas tradições, seus costumes, os seus modos de ser, que é isso que garante a terra para eles. Agora é claro, Liderança2, você sabe muito bem que antropólogo não tem força política nenhuma, porque a gente não tem dinheiro, antropólogo é professor que ganha pouco e muitas vezes eu botei o meu dinheiro, do meu salário de professor para fazer pesquisa em área indígena. Porque muita vezes eu não tenho, porque governo não está preocupado com isso, os políticos não estão, os fazendeiros não querem saber de antropólogos, na verdade, antropólogo só incomoda, então eu não posso deixar aqui promessas, porque também eu não sou mulher de promessas, porque eu também já quebrei muitas promessas, nesses 20 anos, trabalhando com populações indígenas e também já tive muita frustração. Agora, eu não desisti ainda. Eu ainda acho que trabalhar em aldeias vale a pena e eu gostei muito do senhor dizer isso porque de fato, se o meu trabalho não servir para nada aqui então eu nem quero colocar a 'colher', por que a minha idéia é o que? Eu acho sim que é importante que tenha antropólogo e arqueólogo em área indígena trabalhando. Por que isso faz o que? Faz com que as áreas ganhem o que a gente chama de 'visibilidade'. É muito fácil dizer: ah, eles não são mais índios.

Liderança2: Igual pra nós aqui...

Arqueólogo1: É muito mais fácil de dizer, ah isso aqui não é área de índio, pode bloquear, eles têm luz elétrica, eles tem casa, eles têm quintal de concreto, usam roupa, assim- 
Essa assimetria não é responsabilidade da equipe presente nesse determinado momento no campo. É uma conseqüência de um processo muito mais abrangente que excede a prática da arqueologia, sendo, porém, a arqueologia parte dessa prática hegemônica, que alguns autores se referem como colonialista (Smith \& Wobst, 2005). Já que os índios reconhecem que a fala dos arqueólogos está mais próxima de uma fala tida como "correta". Portanto, linguisticamente também há uma assimetria muito grande. A fala dos arqueólogos vale mais do que a dos índios.

Exemplo 2 (forma invertida): Liderança2: Da minha parte, poderia trabalhar porque a gente aqui dentro mesmo pode ver o trabalho, como ela (Arqueológo2) falou...

Deixar arqueólogos trabalharem porque se pode "ver" o que fazem implica - no contexto em que se outorga a permissão do fazer - pôr em jogo a idéia de que eles (os índios) se constituem como testemunhas do trabalho especializado do outro, legitimando-o e autorizando-o, no sentido de que eles estão presentes nessa ação. Os índios podem fazer e decidir dessa maneira porque são os "outros" que chegam ao "seu" território, é o seu espaço que será impactado pela prática arqueológica. Estaria resolvida a assimetria a qual chamamos atenção nessa interação? De forma alguma, pois é a partir da sugestão do arqueólogo2 que os índios aceitam a proposta de presenciar o processo de investigação.

Tendo como exemplo esses dois marcadores de situações assimétricas em campo, e retomando a questão de que estamos inseridos em um contexto maior de produção acadêmica que remete a uma lógica de um modo de produção específico, cabe a

assado e não são mais índios, e isso tem que acabar (o preconceito), tem que acabar! Recentemente, no meu trabalho com os Assurini do Xingu, fizemos todo um resgate da história deles, dos costumes e tudo mais que é uma coisa que nós trabalhávamos na escola porque a gente também percebeu que é na escola, embora ela seja coisa de branco, que pode ter muito da cultura indígena que tem que ser aproveitada. Para que as crianças cresçam com esse orgulho daquilo que elas são, essa é uma preocupação que eu tenho. Porque como professora eu não tenho dinheiro para fazer as coisas, eu não tenho poder de ir lá em Brasília e mobilizar, mas eu tenho sim possibilidade de ajudar a formar essas crianças, contribuir na formação dessas gerações e preservar esse conhecimento, mas eu acho que tem que ter ajuda da aldeia sim, porque a escola indígena é um lugar onde essas coisas podem ser transmitidas. E outra coisa que eu acho também, muitas vezes, o conhecimento dos velhos da aldeia não é valorizado porque os jovens não querem mais falar com o pai, com o avó e nem com ninguém, porque isso: “o meu pai é velho, meu pai é atrasado, agora a gente tem que se preocupar é aprender a fazer, sei lá mexer com o computador e não sei lá o quê", mas eu acho que não, acho que quando a gente, fazendo um trabalho de história, de incentivar a contar,'o seu pai tem muito para te dizer, do passado desse lugar, da história dele, como que era'. Claro que as coisas mudam e os jovens vão querer sempre mudar, mas é uma coisa que a gente tem sim, eu tenho uma preocupação em fazer isso, eu acho que o meu trabalho ele tem que ajudar nisso: a fazer com que as populações indígenas 
pergunta: é possível constituir relações simétricas em campo?

É essa uma discussão que, seguramente, seguirá por décadas e está longe de ser resolvida. Porém, a reflexão metodológica, por si só, que contenha essa questão é um avanço para o questionamento do ranço colonialista da arqueologia.

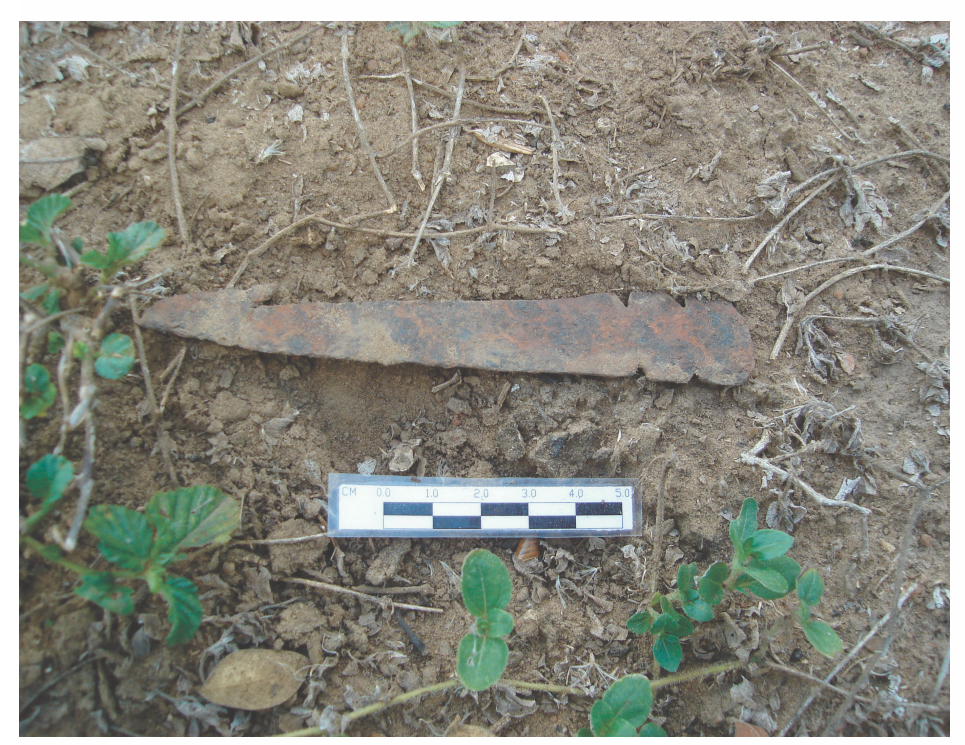

ponta metalica de lança guaicurú

Foto: Eduardo Bespalez

\section{Expressões sobre percepção temporal}

No caso de Lalima, os antigos vestígios arqueológicos são associados às "taperas", moradias dos antigos que, na memória individual, aparecem na experiência e na percepção dos mais velhos, no tempo em que eles eram crianças ou nas estórias contadas por seus pais e avós. "Liderrança1: Aqui nós também temos essa tapera que foi dos nossos antepassados,

pra cá nós também temos na fazenda do Potrero (parte sul da aldeia lalima)... nessa da entrada, porque a minha mãe conhece tudinho ali."

Esse olhar etnográfico pode revelar interpretações temporais até então inesperadas sobre os vestígios arqueológicos. Um bom exemplo disso é a sugestão que Anne

sejam valorizadas.

Porque também às vezes é um engano pensar que o trabalho da pesquisa, só porque ele fica na universidade ele não é divulgado. $\mathrm{O}$ que não é verdade, porque a universidade é também formadora de opinião, quando a gente dá aula para uma turma de quarenta alunos e a gente mostra o trabalho da gente para esses quarenta alunos que estão lá na universidade, a gente diz para eles, "olha aqui, tem gente que vive de modo diferente de vocês, e essas pessoas precisam ser respeitadas", então às vezes parece que o trabalho da gente não está ajudando, mas mesmo quando a gente está dando aula, a gente está ajudando sim, porque a gente está formando a opinião desse pessoal que daqui a pouco vai dar as regras na política, e que vamos formar não sei quantos Darcy Ribeiro ou Roberto Cardoso de Oliveira. Em grande parte as populações indígenas foram valorizadas por esses trabalhos que foram feitos, por essas pessoas que entenderam e que divulgaram esse conhecimento sobre essas populações e os materiais sobre ela para outros lugares. È como se a gente fizesse uma propaganda dessas populações lá fora, no mundo dos brancos, então é isso eu acho que, na verdade, a minha vida toda eu fiz isso. É isso que dá sentido para aquilo que eu faço. Eu não tenho o menor interesse em entrar numa aldeia e não fazer isso. Eu trabalho, eu tenho meu salário de professora eu dou minha aula, eu não venho para cá para 
Christine Taylor (1998) faz sobre os Jivaros, quando ela observa que os restos arqueológicos não são relacionados aos antepassados, mas com entidades míticas, os Iwiach. Ou mesmo quando Silva (2002) mostra a interpretação Assurini sobre as marcas de indústrias líticas (bacias polidores, entre outras) associadas à entidade mítica Maira.

Porém, durante a prática de explicitação de uma pesquisa arqueológica frente a comunidades tradicionais, certos cuidados devem ser tomados para não tomarmos uma postura colonialista. Essa postura é observada quando o arqueólogo pretende contar a história de um povo a despeito do que esse próprio povo pensa sobre a sua história. (Zimmerman, 1994)

A consideração de uma explicação êmica é um contraste marcante com o primeiro impulso explicativo do pesquisador pela chave dos antepassados. É importante ressaltar esse ponto, já que as políticas de educação patrimonial tendem a impor essa noção de antepassados (e a visão de passado), muitas vezes estranha à realidade local. Nesse sentido, resta reflexão de como trabalhar junto a essas comunidades respeitando suas próprias noções de tempo.

$\mathrm{Na}$ literatura antropológica, por muito tempo, se pressupôs que as populações indígenas teriam a mesma noção linear típica da nossa cultura ocidental (passado/presente/futuro). Hoje, esse ponto é visto como uma das principais vigilâncias epistemológicas no trato com os povos indígenas. A compreensão da possível existência de uma outra noção temporal não só enriquece o trabalho de pesquisa como aproxima a população local do próprio trabalho. Um exemplo dessa aproximação baseada na interlocução é a obra First Time de Richad Price (1983), que realiza um estudo aprofundado da memória e percepção temporal dos Saramaka do Suriname, que conduz a construção textual da obra.

ganhar dinheiro, eu venho para cá porque essa é a minha vontade, contribuir com o que eu já aprendi e aprender mais e tentar preservar esse modo de vida porque eu respeito isso e eu acho que é assim que tem que ser. As populações indígenas no Brasil têm que ser preservadas no seu modo de vida, os índios precisam da sua terra garantida para terem o seu modo de vida garantido e se eles quiserem mudar tem que ser uma coisa deles, que deve partir deles, e não uma imposição de fora para dentro 'de que vai virar tudo colono, que vai virar agricultor, que vai virar funcionário de empresa, de indústria ou qualquer coisa assim', então eu acho que enfim, essa é...., eu estou sendo muito sincera porque é isso que eu quero na verdade... fiquei muito impressionada com a aldeia, eu gostei muito do que eu vi aqui, eu sei que vou aprender muito, mas eu também quero contribuir, por que isso é uma coisa que vai me deixar...

Liderança2: Fortalecer né?

Arqueólogo2: Se eu puder ajudar a fortalecer a aldeia Lalima na sua cultura mesmo, acho que eu vou ter cumprido com o objetivo que eu me dispus ao vir para cá.

Liderança2: É essa questão que eu ia falar. É isso que nós precisamos, de uma pessoa que ajuda a gente a resgatar, porque sem essa pessoa não tem como...

Agora, pra gente resgatar o nosso idioma que 
No aspecto arqueológico, trabalhos como os de Claire Smith \& Martin Wobst (2005) e lan Hodder (2000) demonstram as possibilidades de uma intervenção arqueológica marcada por um forte aspecto reflexivo e descolonialista.

Assim, observações aprofundadas quanto à dinâmica cotidiana do trabalho local ou as constantes divagações mobilizadas pelas lideranças sobre a condição social indígena fazem toda a diferença na operacionalização de uma pesquisa arqueológica, como podemos observar nas falas finais da reunião do conselho entre o Vice-cacique e o Arqueólogo2, ela mesma, pressupondo uma dinâmica temporal própria de trabalho. Portanto, as percepções sociais e temporais apresentadas não desqualificam a ciência como produtora de "verdades", mas enfatizam o caráter relacional que ela possui; ela é mais uma produtora de verdade.

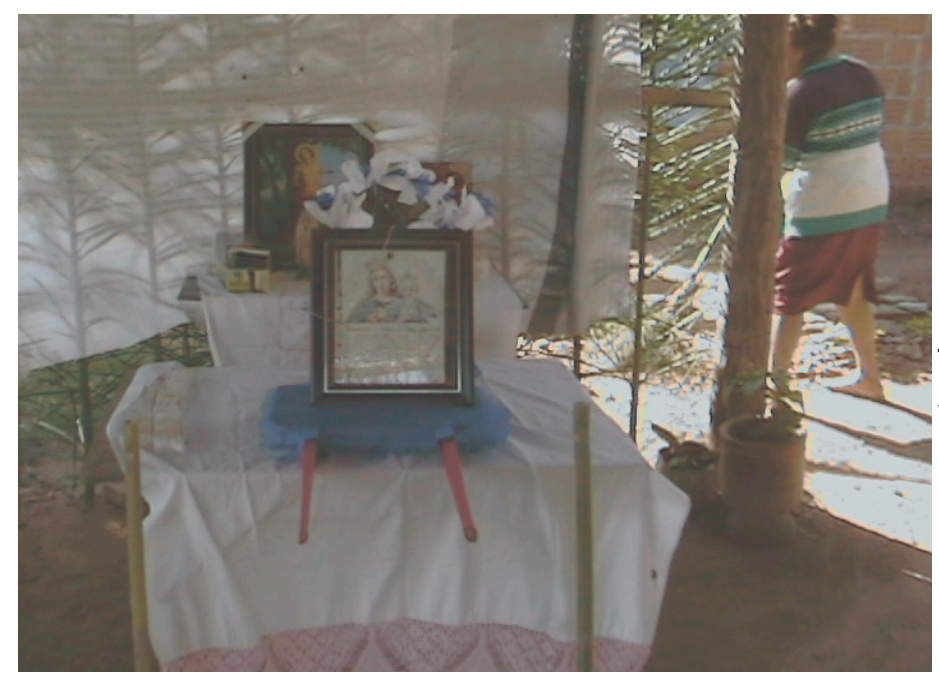

IImagem da Festa do Divino em Lalima

Marcadores de diferença e natureza do outro

O que nos chama atenção na fala do ancião3 é a possibilidade de vislumbre da noção de "antropologia reversa" (Wagner, 1981:31). Wagner chama de antropologia reversa a operação lógica feita por povos indígenas a despeito de conceitos, no caso
mplo, explorado por ele sobre os melanésios, a tradução de 'cultura' (tendo como parâmetro a sua própria cultura) seria algo próximo do termo "cargo". Essa operação lógica, no entanto, aparece

perdemos há muito tempo... o nosso idioma é a nossa natureza...

Tem que começar de menininho, hoje pra daqui cinco anos para frente até dez, eles vão apreender, mas apreender como? Tem que falar com eles, porque se escrever no quadro eles vão ler, isso quando lê, mas do que adianta ensinar a ler e escrever, se ele não consegue falar! Porque aqui tinha um professor de idioma, e quantos anos ele não ensinou o idioma terena e os alunos não conseguiram apreender a falar com o professor...

E não conseguem porque os maiores, hoje, não falam mais, não querem mais falar, têm vergonha de falar...

São esses que estão com 18, 19 anos, 15 ..., então tem que começar com os pequenos agora. Para que em 10 anos eles tenham o idioma perfeito, porque só assim nós vamos ser respeitados em outros lugares. Porque se não colocarmos uma exposição no nosso idioma, ninguém vai respeitar... Ninguém vai dar direito a nossas terras não vai dar direito 
simbolicamente invertida no seu sentido.

"The fact that 'cargo' and 'culture' metaphorize the same inter societal relation, while doing so in opposite direction, so to speak, makes them effectively metaphorizations of each other. 'Culture' extends the significance of technique, mode, and artifact to human thought and relationship; 'cargo' extends that of human relation and mutual production to manufactured artifacts: each concept use extensive bias of the other as its symbol."(WAGNER 1981:32)

A operação lógica desenvolvida pelo ancião3 segue, portando, esse sentido de antropologia reversa. O que chamaríamos de 'cultura' ele chama de 'natureza'. A natureza do índio é diferente da natureza do branco.

Arqueólogo3: Aliás o senhor falou uma coisa muito legal naquele dia (da reunião do conselho indígena), que eu queria perguntar, que você falou que 'a natureza do branco é diferente da natureza do índio'.

Ancião3: Ah, mas toda a vida.

Arqueólogo3: Toda a vida?

Ancião3: Toda a vida. Ah. Não chega nunca, nunca chega.

Arqueólogo3: Nunca chega a ser?

Ancião3: Nunca chega né... nunca chega porque a nossa natureza ela já vem de nascença, nunca ela vai bater junto. Agora entre o trabalho e outras coisas pode ser que ainda vai chegar, mas a própria natureza, não.

Arqueólogo3: Não..?

à coisa nenhuma.

Precisa sim receber, acompanhar, afirmar e pedir aos professores: "olha, agora, daqui pra frente, nós vamos por esse caminho". Porque nós somos índios e não temos o nosso idioma? Não pode! È importante.

Antigo Cacique: Agora quando você fala, na comunidade nunca veio ninguém aqui falando: "Eu vou trazer coisas pra vocês aqui, pra fortalecer vocês" eu agradeço a sua vinda e a ajuda que vocês querem fazer para a nossa comunidade e é de grande interesse, e eu consegui gravar tudo aquilo que estávamos discutindo aqui, o que a Liderança2 falou. Quem sabe se a gente tivesse tido um Darcy Ribeiro para saber, nós já não teríamos demarcado as nossas terras, quem sabe se tivéssemos tido pessoas como vocês, que vêm da universidade querendo conhecer, louvar a nossa história para ser conhecida a nível nacional, não teria acontecido coisa melhor para nós. Não estaríamos aqui, jogados sem saber se existimos ou não.

São coisas difíceis que nós viemos enfrentar ao longo do tempo. Graças a deus! Que hoje já recebemos toda informação digital, que seria o desenvolvimento para o filho que está estudando, agora a gente recebeu o pessoal universitário lá de São Paulo para fazer uma pesquisa baseada naquilo em que nós vivemos desde que os nossos primeiros ancestrais existiram por aqui, e que acabaram por aqui. Nós não sabemos contar a história deles e através desse trabalho nós vamos começar a ter mais noção de saber contar. Fiquei feliz quando vocês falaram que querem aproveitar a escola. O nosso professor precisa se habilitar e ver o material e o que está faltando 
Ancião3: Não bate, nunca vai bater, nunca vai chegar.

Arqueólogo3: Por quê? (13:45)

Ancião3: Porque o nosso convívio né, são assim dos antepassados, veja bem, nós índios, eu como índio sou da tribo Kinkinaw com Layana, meu pai era Kinkinaw e minha mãe Layana... finada minha mãe. Meu pai faleceu no ano passado com 109 anos de idade, ele nasceu e criou aqui sempre. Ele era Kinkinaw, finado meu avô morreu com 119 anos.. (momento de tristeza)

(...)

Ancião3: Como eu estou dizendo (na reunião do conselho indígena) a natureza nunca vai chegar.

\section{Arqueólogo3: Nunca vai chegar?}

Ancião3: Não chega porque o que nós temos como o senhor vê agora ali né os brancos procuram e não usam né.

Arqueólogo3: O que é que não usa?

Ancião3: Não usa, por exemplo, o fogo no chão, os remédios do mato, não usa, por exemplo, pular o fogo, esse é um mistério de afastamento das maldades, que muitas vezes vai afetar a família, chegando na família, destruindo a família. São os mistérios da natureza que os próprios índios, isso vem de nascença, conforme iam nascendo e morrendo ia passando de pai para filho. E iam aprendendo.... até hoje mesmo, os meus netos, muitas vezes eles estão chorando e a mãe dele não sabe o que é, eu digo: ' pinta ele'. Pega o carvão de panela e pinta ele no rostinho que ele fica tranqüilo, por causa os espíritos do mato. Os brancos não têm isso né, eu tenho certeza que não têm, mas nós que somos velhos e com a própria natureza do mato, existe a

para eles, para que no futuro os nossos filhos reconheçam aquilo que eles já perderam. Chamar essa criançada e falar a língua terena, mas se houver um resgate do passado de 1940, e vir o pessoal, antropólogos como o Darcy Ribeiro que encontraram lá fora aquilo que nos perdemos...

Quem sabe o Arqueólogo1 que gosta de cultura, leva 20 anos para resgatar essa cultura que nós perdemos e língua não se aprende na escola. Porque lá na Cachoeirinha, por exemplo, o pessoal fala com as crianças na língua, passa de pai para mãe, já conversam naquele idioma. Aqui nós somos diferentes, num fala, num fala, num fala, e vamos falar que somos índios? E a língua portuguesa, não sabemos se falamos um dialeto ou português... Então era isso que eu queria deixar aqui e dizer que da minha parte estou muito contente.
Vice-Cacique: Eu tenho uma pergunta para vocês, a nossa gestão vai começar a trabalhar agora, e eu queria saber de vocês se o trabalho de vocês vai começar agora, agora?

Arqueólogo2: Segunda-feira.

Vice-Cacique: Porque da minha parte eu queria dizer que eu queria um tempo para nós discutirmos. Pelo menos um mês...

Arqueólogo2: Sabe por que pra nós é complicado isso? Porque na verdade nós estamos um ano já batalhando a licença da Funai, e a licença saiu. Nós entendemos que o conselho é novo, eu sou professora, tenho todos os meus compromissos, eu larguei tudo em São Paulo para vir para cá começar a pesquisa porque a Funai autorizou a gente a entrar e a fazer porque tinha já o outro conselho que permitiu. Na verdade, eu gostaria que esse conselho fosse 
natureza. Os bichos da natureza do mato existem. Porque, veja bem, que quando ele quer fazer o senhor perder ele faz, dentro do mato, ele faz o senhor perder, basta só duvidar com ele e falar "eu duvido que vou perder" pois ele faz você perder, pode ser no lugar mais conhecido que sempre vê, mas ele faz você perder..

Arqueólogo3: Mas faz perder....

Ancião3: Faz o senhor virar a cabeça que não sabe nem onde tá, isso existe, e para livrar disso o que fazia? Saia pintado... pintava no rosto e seguia para o mato. Criança principalmente, aquela que falavam que era pagão, criança que não é batizada que nunca cantaram para ele, esse ai ninguém saia com ele, porque o espírito das matas, os espíritos da natureza, então, pegava ele. Eles (que eram pegos) não dormiam e às vezes morriam. Alguns que custavam descobrir (que foram pegos) morriam. Então assim é a natureza de nós no mato. O senhor vê hoje, eu, por exemplo, nos estamos conversando, alguma coisa de entre nos dois se pega! No olhar, no conversar, alguma coisa, por exemplo, daqui a pouco o senhor pode está sentindo uma dor de cabeça, mas não é! São as naturezas (sua e minha) que não se combinaram na hora de um para outro, e por isso o senhor sentiu dor no corpo. Então o que eu faço? Vou sair aqui e subir nesses matos, vou lá nas matas, lá eu ando por lá, faço o que tenho que fazer - o mistério da natureza, e quando volto tem um tormento. Sai tudo (a dor), sai tudo, tudinho... Então, é por isso eu digo que a natureza do branco nunca vai chegar (se encontrar) com a natureza do índio. Pode chegar no trabalho, dirigir um trator, plantar na máquina, essas coisas chegam, mas na própria natureza nunca vai bater, não vai, porque a nossa natureza é diferente, vivemos de outros tipo de né..... de outras convivências.

compreensivo com a gente e que deixasse que a gente começasse o trabalho, já que a gente tem autorização oficial, a gente está legal, e nesse mês que vocês precisam para conversar, vocês conversassem conosco. Nós iremos vir todos os dias na aldeia. Porque senão iremos perder tudo que fizemos até agora.

Vice-Cacique: Porque é a primeira vez que a gente está participando da liderança...

Arqueólogo2: Eu entendo a sua situação, mas assim, eu gostaria que o senhor também entendesse um pouco o nosso lado. Porque a gente não pode voltar pra São Paulo esperar um mês, porque a gente gostaria de estar discutindo com vocês esse mês e vocês verem o que nós estamos fazendo. Porque nós temos a autorização, batalhamos muito pra chegar até aqui. Entendemos que o conselho é novo por isso que a gente está aqui se apresentando, mas gostaríamos de poder começar o trabalho e vocês nos acompanham discutindo ao longo desse tempo.

(...)

Vice-Cacique: Então é como estou dizendo, como a Liderança2 falou, somos muito novos pra esse negócio de fazer promessa...

Arqueólogo2: E eu também, como expliquei, eu não quero fazer só uma promessa, eu quero poder fazer o meu trabalho, até porque eu também vim aqui com a boa vontade de fazer, então, assim, eu acho que é uma coisa ... como antropóloga eu tenho essa vontade, e eu quero ser bem-vinda aqui e quero contribuir. Então, eu gostaria que a gente pudesse começar esse momento de confiança mesmo, e aí, se vocês um dia disserem, "olha Arqueólogo2, a gente não está gostando, não está adiantando nada, você é mais uma pessoa que veio para cá e 
Esse jogo de espelhos, a percepção de natureza de si e do outro, posta por ele se aproxima da noção de multinaturalismo colocada por Viveiros de Castro $\left(2002^{\mathrm{a}}\right.$; 2002b) - e o conseqüente desenvolvimento teórico do perspectivismo. A seguinte passagem da Inconstância da Alma Selvagem esclarece um pouco mais essa relação:

"[...] Esse reembaralhamento das cartas conceituais leva-me a sugerir o termo multinaturalismo para assinalar um dos traços contrastivos do pensamento ameríndio em relação às cosmologias 'multiculturalistas' modernas. Enquanto estas se apóiam na implicação mutua entre unicidade da natureza e multiplicidades das culturas - a primeira garantida pela universalidade objetiva dos corpos e da substância, a segunda gerada pela particularidade subjetiva dos espíritos e do significado - a concepção ameríndia suporia, ao contrário, uma unidade do espírito e uma diversidade dos corpos. A cultura ou o sujeito seriam aqui a forma do universal; a natureza ou o objeto, a forma do particular.

Essa inversão talvez demasiado simétrica para ser mais especulativa, deve-se desdobrar em uma interpretação fenomenologicamente rica das noções cosmológicas ameríndias, capaz de determinar as condições de constituição dos contextos que se poderiam chamar 'natureza' e 'cultura. Recombinar, portanto, para em seguida dessubstancializar, pois as categorias de Natureza e Cultura, no pensamento ameríndio, não só subsumem os mesmos conteúdos, como não possuem o mesmo estatuto de seus análogos ocidentais; elas não assinalam regiões do ser, mas antes configurações relacionais, perpectivas móveis, em suma - pontos de vista. [VIVEIROS DE CASTRO 2002a: 349]"

Essas reflexões teóricas presentes nas falas dos anciões nos conduzem, assim, aos estatutos de simetria sobre o dualismo natureza/cultura.

O principio de simetria começa com a proposição que os humanos e as coisas se constroem simultaneamente (Callon; Latour, 1992; Latour, 1994).

não resolveu nada." Eu vou embora! Eu quero pelo menos poder trabalhar com a confiança nesse momento e começar a fazer, pelo menos a minha boa vontade, eu tenho de fazer.

Vice-Cacique: Inclusive, eu não sei se os outros companheiros concordam, mas eu acho que a gente tem que ter um tempo, que a gente foi pego de surpresa. Estamos entrando agora e eu acho que a gente precisa pegar todo mundo e conversar só nós.

Arqueólogo2: Eu acho que sim, só gostaria que vocês conversassem, e vocês deixassem a gente trabalhar, pelo menos, em cima da licença que já veio. Porque temos que dar satisfação desse trabalho, é só esse pedido que eu faço para vocês.

Liderança2: quer dizer que... eu não sei se estou entendendo muita coisa, quer dizer que além da senhora existe mais outra pessoa para apresentar esse trabalho?

Arqueólogo2: Não, não. $\mathrm{Na}$ verdade eu sou a coordenadora, eu sou a professora.

Liderança2: Eu não estou entendendo, já que a senhora falou que precisa dar satisfação do trabalho.

Arqueólogo2: Não, porque para eu poder vir para cá, você imagina, eu sou da Universidade de São Paulo o que acontece, eu tenho que pedir licença para vir para cá, eu tenho que deixar de dar aula para poder vir para cá, para 
Assim, os "sujeitos" e os "objetos", carregados de conotações pela modernidade, vão ser vistos segundo Latour (1993) como os "produtos" purificados das nossas particulares relações com o mundo. Pensamento e ação, idéias e matérias, passado e presente aparecem completamente misturados na realidade. Portanto, no plano ontológico, a qualidade de natureza serve, inclusive, como marcador étnico, não só em relação ao branco, mas também para outras etnias.

Ancião3: (...) então são assim a nossa natureza, sempre falo, a natureza nossa é diferente do que existe aí. É diferente do estudo, do computador e essas coisas, mas não vai virar nós nunca, nunca vai desvirar nós, 'não agora eu sou o branco', isso não... o nosso saber aquilo vai por natureza, nasceu ele já tem a natureza dele perfeita.

Arqueólogo3: Ah, nasceu já tem.

Ancião3: É já existe a natureza perfeita, já nasce (o índio) com o saber dele. (...)

Arqueólogo3: Qual a diferença entre os Terena e os Cadiweu?

Ancião2: A diferença é pouca... É que nos não une, não procura união...

Arqueólogo3: Porque que não?

Ancião2: Não sei... É a natureza... Porque cada um tem a sua natureza.

Arqueólogo3: Como que é a natureza do Cadiweu?

Ancião2: A diferença, por exemplo, é que nos todos aqui somos Cadiweu eles lá são Laiana, nós não proseia , mas pode passar por ali...

Arqueólogo3: E como que é a natureza do branco?

Ancião2: O branco tem muita leitura... desde cedo vai pra escola

poder passar um mês, aí então, essa que é a minha complicação. Então é por isso que eu tenho uma preocupação com isso.

Liderança2: Da minha parte, poderia trabalhar porque a gente aqui dentro mesmo pode ver o trabalho, como ela falou...

Arqueólogo2: Claro, eu acho que a gente pode tentar.

Antigo Cacique: Eu concordo também com que ela falou... 
Arqueólogo3: A diferença do Cadiweu para o Terena?

Ancião2: Ah, é muita... agora, faz muitos anos depois que terminou a guerra, não foram lá pra baixo trabalhar na divisa dos Cadiweu. Agora é tudo diferente, é tudo civilizado esses índios aí. Cada rapaz loiro...moça...Na outra Aldeia, o senhor dá um pulo lá pra ver como que é... lá eles falam só idioma.

Tal abordagem teórica levantada pelos dados etnográficos, pode a primeira vista não desenvolver nenhuma relação com a arqueologia. No entanto, devemos considerar dois pontos para a nossa reflexão. O primeiro, é que os dados etnográficos foram levantados em um determinado contexto, e justamente esse contexto é decorrente da pesquisa arqueológica feita na Aldeia Lalima (e Kaiabi também, como veremos mais adiante). Ou seja, a mobilização do saber indígena foi feita em relação à nossa presença (cientistas/arqueólogos/brancos). O segundo ponto se refere à possibilidade teórico- metodológica de a arqueologia interagir com tal perspectivismo ameríndio. Poderíamos refletir quais seriam as possibilidades (e conseqüências) para a disciplina em uma pesquisa baseada na lógica e mobilizações ontológicas indígenas. Por exemplo, junto à noção de antropologia reversa apontada acima, podemos pensar a aproximação de uma prática arqueológica no questionamento do dualismo básico -

tão caro às Ciências Sociais - de natureza/cultura. O aprofundamento teórico, em termos antropológicos, desse dualismo proposto por Latour (1994) na sua Antropologia Simétrica, permite alguns autores fazerem/procederem o reordenamento interpretativo de dados arqueológicos. O trabalho de Andrew Martin (2005) segue essa premissa quando faz o esforço interpretativo sobre os vestígios arqueológicos dos Mounds do vale do Mississipi, considerando estes como 'centro de cálculo' para a visão nativa de mundo.

Ou mesmo propostas mais 'radicais' de subversão da prática empiricista. Se a prática arqueológica reflete valores ocidentais, como seria uma prática arqueológica que refletisse valores indígenas? Tara Million (2005), arqueóloga e indígena, em seu artigo "Developing an Aboriginal Archaeology: receiving gifts from White Buffalo Carlf Woman" ensaia uma escavação arqueológica baseada em seus valores (e tabus) indígenas, subvertendo a ordem cartesiana de elaboração do dado arqueológico. Alguns poderiam acusá-la de não ser científica o suficiente, mas como bem lembra o Ancião3, 'a ciência do índio é diferente da do branco'.

O que é certo é que a potencialidade teórica trazida pelo cruzamento de perspectivas traz um salto qualitativo nas pesquisas arqueológicas. Como é o caso da arqueologia simétrica feita por Shanks (2007), Olsen (2003) e Witmore (2006) onde o dado bruto da arqueologia sede lugar aos aspectos relacionais (agency) por ela desenvolvidos. 


\section{capitulo 3}

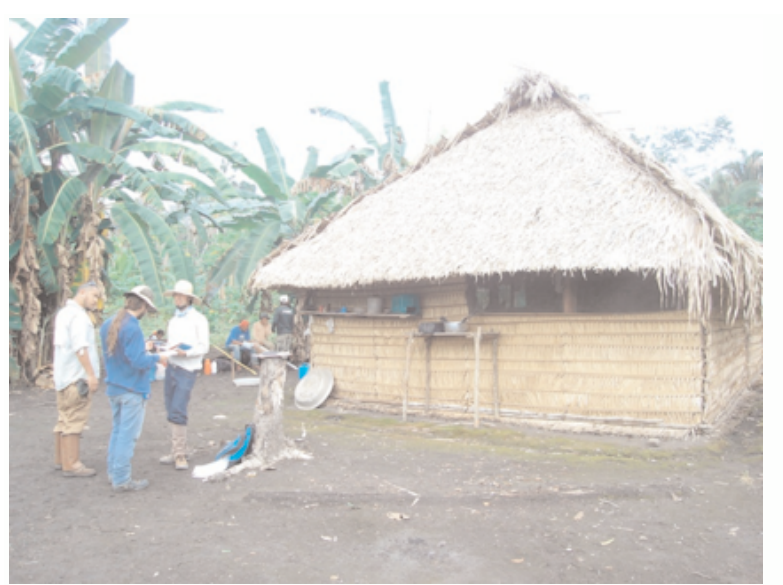

Casa Kaiabi

\section{A experiência etnografia na Terra Indígena} Kaiabi.

Através dos relatos do viajante francês Francis de Castelnau, no século XIX, encontramos a primeira menção aos Kaibi em documento escrito:

"Les Bacchayris, qui habitant les sources de l'Arinos, sont des moeurs trés

douces;...ils sont en guerre avec les Cajahis. Les Tapanhunas, tribu hostile, sont établis sur une riviére de même nom qu'eux, Qui est un bras de I'Arinos; ils parlent la même langue que les précédents; ils se teignment entiérement en noir."

(CASTELNAU 1850)

A partir de então vários outros documentos fizeram menção aos Kaiabi utilizando diferentes grafias para o nome: Cajabis, Caiabis, Cayabi, Kaiabi comumente se referindo à hostilidade da etnia (STEINEN, 1940).

As principais etnografias feitas sobre os Kaibi, cuja língua se enquadra na família TupiGuarani, são os trabalhos de Georg Grünberg (Grünberg et al 2004), uma etnografia geral sobre o grupo produzida a partir de pesquisas realizadas nos anos 60; de Elisabeth Travassos (1984; 1993) sobre xamanismo e música; de Suzane Oakdale (2005) sobre narrativas, agência e performance; e ainda, sobre cultura material, Berta Ribeiro (1986) fornece importantes informações sobre o grupo.

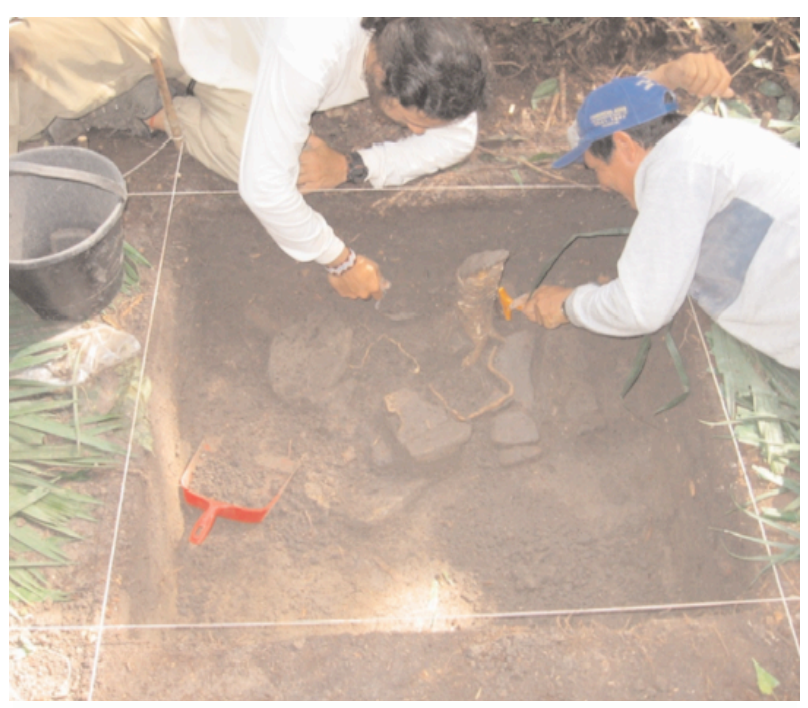

Possivel estrutura arqueólogica no Sitio Dinossauro
Diáologos sobre a possivel estrutura arqueólogica

Primeiro momento, final da noite.

Arqueólogo1: Por que não escavar só uma quadra?

Arqueólogo2: Porque ele encontrou a beirada de algo que pode ser maior.

Arqueólogo1: Tudo bem, mas não é a proposta do trabalho escavar a estrutura de um sítio. 
Os Kaiabi resistiram (e resistem) com vigor à invasão de suas terras por seringalistas e latifundiários desde o final do século XIX. A partir dos anos 50 , com a política colonialista de ocupação da Amazônia, a região dos rios Arinos, dos Peixes e Teles Pires foram retalhadas em glebas que viraram fazendas e os Kaiabi se dividiram em três grupos.

Parte da etnia foi transferida para o Parque Indígena do Xingu, pelos irmãos VillasBoas, há cerca de 45 anos. Uma outra parte permanece na sua área ancestral que é a região entre o rio Arinos e rio dos Peixes (ou Tatuy) e, ainda, algumas outras famílias migraram para as margens do rio Teles Pires (Wyrasing'y), próximo ao rio Cururuzinho, na área fronteiriça entre os estados de Mato Grosso e Pará (município de Alta Floresta, $\mathrm{MT})$, onde foi realizada esta pesquisa.

Sentindo a saturação populacional e a deficiência de recursos naturais para a cultura material, alguns Kaiabi saem do norte do parque do Xingu, onde estão instalados, para a T.I. Kaiabi no Teles Pires, configurando assim, um novo movimento migratório. Em algumas entrevistas, foi-me explicitado que esse movimento migratório, de retorno às áreas tradicionais, é incentivado pelos Kaiabi como estratégia de manutenção de uma identidade cultural baseada não só na garantia de recursos naturais como também na manutenção territorial. Em 1999, foi publicado um Relatório da Funai que aprova o reestudo e a ampliação da T.I. Kaiabi (declarada como Terra Indígena em 2002), aglomerando as nascentes do rio Cururuzinho e garantindo, assim, o uso tradicional e cultural do rio o que, conseqüentemente, se choca com os interesses locais de grandes proprietários de terra e até mesmo com os empreendimentos turísticos e comerciais. Hotéis de selva foram se instalando visando ao turismo

Arqueólogo3: Não podemos perder a chance de escavar uma estrutura dessas. Que pode nos trazer muita informação.

Arqueólogo1: Você mesmo, Arqueólogo2, disse que poderia ser uma opção escavar só uma quadra.

Arqueólogo2: podia ser uma opção, mas...

Arqueólogo3: Escavar outra condiz com os objetivos. Vamos encontrar boas amostras de carvão, que vão estar associados à estrutura.

Arqueólogo2: Eu digo o seguinte, até agora o achado do sítio é essa estrutura. É o achado do sítio! E temos a oportunidade de entender melhor o que é aquilo ali. E a única maneira de fazer isso é escavando mais.

Arqueólogo3: Concordo, mas pensado no que o Arqueólogo1 falou, acho que tem a ver, com relação aos objetivos da pesquisa desse sítio, encontrar amostras melhores de carvão do que aquelas que saíram na primeira quadra da estrutura.

Arqueólogo1: Mas não sabemos se o carvão que já apareceu nessa primeira quadra não é o suficiente.

Arqueólogo2: Acho que não, só se for para MS .

Arqueólogo1: Tem que desmontar a estrutura para saber.

Arqueólogo2: Só se estiver embaixo dela, mas acho que não. $\mathrm{O}$ que tem de carvão é o que já foi encontrado.

Arqueólogo3: Também acho complicado desmontar a estrutura na metade. E voltar em outra temporada ou mesmo nunca mais.

Arqueólogo2: É, eu também, acho que é uma espécie de violência com o sítio.

Arqueólogo3: Ok. Também estamos defendendo a escavação da estrutura por 
ecológico, principalmente o da pesca esportiva. Os Kaiabi desenvolveram uma relação conflituosa com esses hotéis, ora baseada em benefício econômico ora baseada nos conflitos territoriais. Inclusive, algumas vezes, foi-me esboçado a vontade dos Kaiabi de tomarem para si o controle do turismo na região. Outros grupos de interesse são aqueles vinculados à construção próxima de uma barragem hidroelétrica e da futura hidrovia Teles Pires-Tapajós. (ISA; Povos Indígenas do Brasil 1996/2000; p. 484.)

O cenário tenso se agravou recentemente, com uma nova liminar judicial, a favor da fazenda Santa Rosa, controlada pela empresa canadense Brascan, que interrompeu a demarcação técnica já aprovada pela Funai. Essa interrupção aconteceu justamente no momento em que chegamos na área para realizarmos a pesquisa etnoarqueológica prevista no projeto . Concomitantemente, no cenário nacional, se desenrola uma campanha midiática contra a atuação das ONGs internacionais em território amazônico, e a volta de antigos discursos reacionários fundamentados na soberania e segurança nacional, como pode ser observado no caso da área indígena Raposa Terra do Sol, em Roraima. No entanto, nem precisamos ir muito longe para observamos as denúncias contra ONGs internacionais. Logo na fronteira da área indígena Kaiabi, encontra-se o Parque Cristalino, manejado por uma ONG britânica chamada Cool Earth, alvo de denúncias de irregularidades territoriais e éticas . O que nos chama atenção nesse contexto nacional de caça às bruxas, é que empresas internacionais que atuam na área amazônica, em especial as de agrobussines (como a Brascan), foram 'esquecidas' da teia de conflitos que vive a região.

Assim, era de se esperar, como em Lalima, o questionamento constante por parte da comunidade sobre os possíveis usos políticos da nossa pesquisa e o especial

motivos emocionais.

Arquólogo2: É verdade, se vocês quiserem escavar só uma quadra é algo a se pensar.

Arqueólogo3: Mas de qualquer forma, escavar outra quadra não é desperdício de tempo.

Arqueólogo1: Não é desperdício de tempo, mas é refletir sobre a proposta de trabalho da pesquisa kaiabi, que é diferente daquela feita em Lalima.

Arqueólogo2: A metodologia é a mesma.

Arqueólogo4: É a mesma metodologia, mas não quer dizer que sejam os mesmos objetivos. São duas opções: ou trabalhamos na quadra inicial ou ampliamos para outra. Mas não podemos perder muito tempo ampliando e deixar de fazer poços-teste em outros lugares. Principalmente naqueles sítios que prevíamos um dia de trabalho, mas já sabemos que será mais de um. Respeitando a importância que é a estrutura e o material relacionado, com certeza é o achado do sítio. Mas não podemos colocar tudo em jogo aí, temos a questão da logística, do rodízio de pessoas....

Arqueólogo1: Temos também a questão da prioridade do trabalho a ser realizado em cada sítio. Se formos num sítio que o trabalho é um dia, temos que verificar a prioridade dos trabalhos previstos, que podem ser, por exemplo, a coleta de superfície, ou a sondagem.

Arqueólogo3: Mas como você falou, os sítios que havíamos programado de trabalharmos durante um dia, talvez não dê para ser um dia só. Já que teremos que estourar o tempo em algum, melhor que seja no sítio dinossauro. Quando formos a outro sítio e, se encontramos um sepultamento, uma estrutura, 
interesse em fundamentar as suas reivindicações no aspecto positivista que a arqueologia proporciona.

LiderançaKaiabil: (...) e vimos que a pesquisa (arqueológica) iria se feita para nós mesmos: para mostrar para não-índio que ali existia índio.

(...) Isso que a gente foi conversando, quanto mais pessoas, antropólogos ou outros pesquisadores fizerem isso tipo de trabalho, talvez isso seria bom para nós, para mostrar para outras autoridades, enfim os outros que acham que nunca existiu índio na região

Ainda é cedo para se observar o desenvolvimento, por parte dos Kaiabi, de um discurso arqueológico decorrente do nosso contato de pesquisa, em suas reivindicações políticas ao longo prazo. Porém, alguns sinais de possíveis caminhos puderam ser observados, como, por exemplo, o manejo próprio dos vestígios arqueológicos na área e a valorização da etnia no acionamento de narrativas vinculadas à cultura material.

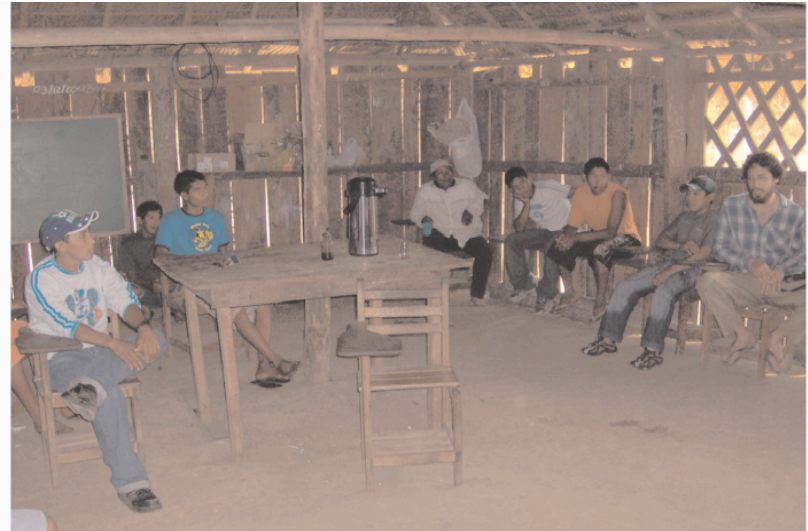

Foto: Francisco Stuchi

Dialogos na escola kaiabi

\section{As narrativas kaiabi}

O aspecto autobiográfico é a característica mais marcante das suas narrativas, é comum o narrador trazer para si alguns aspectos de capital simbólico de acordo com as subjetividades da sua audiência (Oakdale, 2005). Assim, na etnografia apresentada aqui, o discurso modulado articula desde o conteúdo políticosimbólico de territorialização a qualificações pessoais de ser o detentor do conhecimento cosmológico kaiabi, em relação às subjetividades arqueológicas. ou seja, lá o que for. Ai não dá para abrir mais quadras.

Arqueólogo2: Neste caso, em outros sítios, nós paramos. Cobrimos o sítio com uma lona, tapamos a urna. A gente pára.

Arqueólogo3: Porque não sabemos se de todos os buracos que abrirmos sairão só raiz, caquinho, terra preta...

Arqueólogo2: É, são coisas para pensarmos, talvez seja uma boa opção não escavar.

Arqueólogo4: Dormimos então com essas questões na cabeça e amanhã falamos sobre isso no sítio. (...) Mas, para amanhã, dá pelo menos para começar a abrir mais uma quadra na estrutura.

Arqueólogo3: Então, vai abrir mesmo outras quadras?

Arqueólogo2: Não sei, de repente é melhor que tampemos com lona a estrutura. Vamos fazer um croqui (desenho) e nem desmontamos a estrutura. Se sobrar tempo, nós só a evidenciamos e fazemos o croqui. Arqueólogo3: Você acha então que vai ter mais carvão? 
Esse aspecto narrativo está presente na formação das lideranças Kaiabi e, conseqüentemente, valoriza a relação entre o pesquisador e a comunidade local, colhendo para si (a liderança) os créditos desta relação, pela narrativa autobiográfica. Os principais causos, justamente, foram colhidos durante o jantar conosco, que era também um dos momentos de interação entre os Kaiabi, e onde a dinâmica discursiva se revelava.

A cena etnográfica que articula essas percepções foi a descoberta de uma possível estrutura arqueológica durante a escavação no sítio Dinossauro. Esse sítio se encontra às margens no rio Teles Pires, próximo à aldeia Cururuzinho, ele foi o primeiro sítio a ser escavado e, conseqüentemente, o primeiro sítio que atuou sobre as percepções e narrações dos atores envolvidos nesta pesquisa.

Esta cena é perpassada por três momentos, que configuram, inclusive, uma exemplificação do nosso cotidiano na aldeia. No primeiro momento, discutimos, após o jantar, ainda excitados com a descoberta, as possíveis estratégias de atuação sobre a estrutura arqueológica. Esse planejamento de campo é feito entre a equipe de arqueólogos sem a presença dos índios. Em um segundo momento, logo no café-damanhã, abrimos a discussão sobre as nossas possíveis decisões para os auxiliares de campo que costumavam tomar café conosco. E, por fim, o terceiro momento é quando estamos no sítio, próximos à quadra da estrutura, e percepções de atuação são esboçadas tanto por parte dos arqueólogos quanto pelos companheiros indígenas de trabalho.

Arqueólogo2: Não, acho que não sai mais. Mas o que temos é o suficiente para datarmos. Arqueólogo3: Já saiu uma quantidade razoável?

Arqueólogo2: Já. Tem uns grãos maiores e amanhã dá para pegar mais alguns.

Arqueólogo3: $\mathrm{E}$ esses fragmentos da estrutura, podemos coletar para TL ?

Arqueólogo2: Tem, mas não vamos nem desmontar a estrutura. Porque iremos desmontar ela então? Nem vamos coletar aquele material.

Arqeuologo3: Faz assim, vê o que dá para pegar de carvão e o que dá para pegar de cerâmica para datação.

Arqueólogo2: Se for para parar, então nem vou desmontar a estrutura. É o que você falou arqueólogo3, escavar pela metade não compensa, cortar a estrutura também não dá.
Sabemos que a estrutura está inteira e ficará lá, como aqui é terra indígena, não irá acontecer nada com ela.

Arqueólogo1: Então ok, já que a pessoa responsável pelo terreno é o diretor da escola indígena. Ter um exemplo de estrutura arqueológica no terreno do diretor da escola é uma coisa legal.

Arqueólogo2: Não, Arqueólogo1, primeiro temos que gerar conhecimento. Se fosse para expor uma estrutura nesse sítio teria que ser uma outra. Talvez em outro lugar.

Arqueólogo1: Tudo bem. Conhecimento para quem?

Arqueólogo2: Para eles próprios, acho que eles estão muito interessados em saber que vasilhas eram aquelas. Acho que nesse sítio tem milhares como aquelas, acho que não é o momento de usar aquela estrutura para fins 


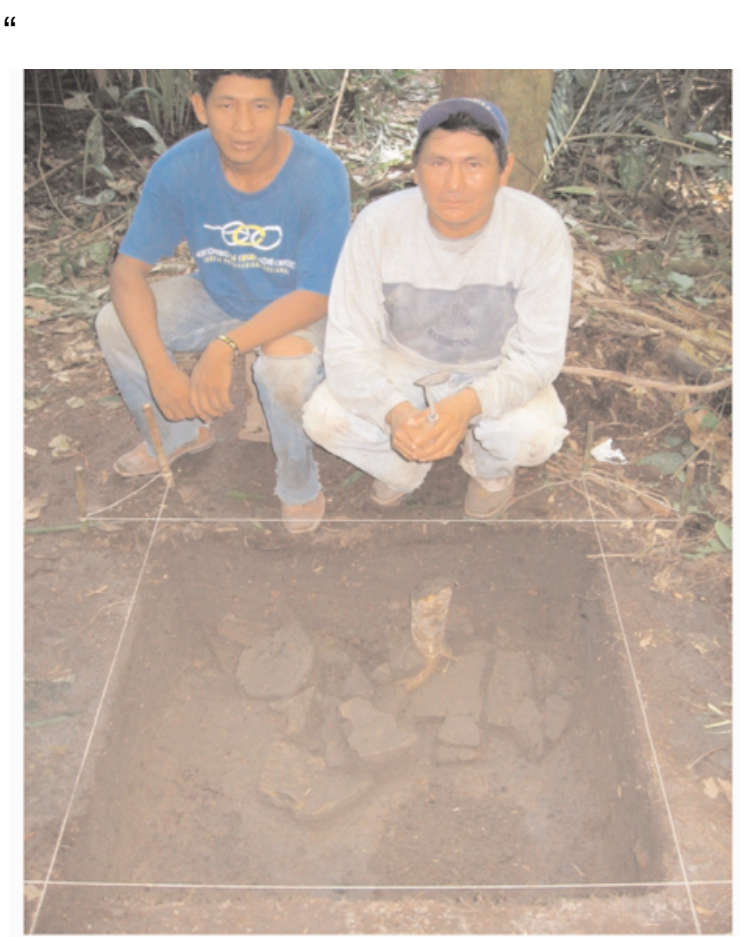

Auxiliares de campo kaiabis

\section{É o achado do sítio!"}

Comecemos pelo próprio ato de descobrimento do conjunto cerâmico. $\mathrm{Na}$ seqüência das falas do 'primeiro momento' $e$ 'terceiro momento' podemos perceber o jogo discursivo mobilizado na garantia do reconhecimento da descoberta. É a atuação do regime de verdade cientifico. No caso, decorrente da seguinte afirmação do Arqueologo2, "Eu digo o seguinte, até agora o achado do sítio é essa estrutura. É o achado do sítio! E temos a oportunidade de entender melhor o que é aquilo ali. E a única maneira de fazer isso é escavando mais."

"É o achado do sítio!" reconhece não só o valor do artefato como também legitima e credencia o seu conhecimento enquanto arqueólogo, é a mutua constituição de ator (social agent) e fato. Situação similar ocorreu na passagem do 'terceiro momento': "Eu não sei, talvez deixar de registrar um ou dois sítios para terminar a estrutura nesse sítio seja melhor. Essa é a minha opinião de arqueólogo!". É a mesma situação quando

educativos. Acho que aquela estrutura tinha que ser escavada. Se quiserem deixar alguma coisa exposta para posteridade, acho que tem que ser uma outra. Aquela estrutura tem que ser escavada, tem que ser desmontada inteira. Nós nem sabemos o que ela é. Como as vasilhas foram feitas? Como que a estrutura foi feita? Aquilo foi quebrado? Acho que antes de deixar alguma coisa exposta para os Kaiabi temos que, pelo menos, interpretar a estrutura. Com base em tudo, na postura arqueológica, $\mathrm{o}$ que os índios acham dela e etc.

Arqueólogo4: O que o Arqueólogol falou é interessante, mas agora não é o momento, teríamos que vir mais preparado para fazer isso e ao mesmo tempo coletar dados dessa experiência com os Kaiabi. Não estamos preparados o suficiente para fazermos isso agora.
Arqueólogo2: Arqueólogo4, dessa estrutura você não vai poder falar nada, a não ser a data dela que ela existe. É a única coisa que você poderá falar dela, não poderá dizer se é sepultamento, não poderá falar que vasilhas são aquelas.

Arqueólogo4: Mesmo que eu não queira falar nada dela, em termos de usar a estrutura para uma exposição ou termos didáticos, acho que não é o momento agora. Acho que temos que vir mais preparado para isso e outras pessoas terão que conhecer um pouco mais sobre o nosso trabalho. Principalmente aqueles que ainda não trabalharam conosco. Assim, o nosso trabalho na aldeia fica mais conhecido entre os índios, assim viremos mais preparados e quem sabe um dia não fazemos um sítio escola.

Arqueólogo3: então, voltando aos 
Holtorf (2002) descreve a história de vida de um caco cerâmico, em uma escavação no Monte Polizzo na Sicília. Segundo o autor, a expert em cerâmica Emma, não depende inteiramente do jeito que ela classifica o caco, se bem que um erro de classificação pode colocar em perigo as credenciais dela enquanto arqueóloga. No entanto, a contínua classificação de cacos reproduz nela o status de competência na análise da cerâmica: "the sherds needed her, for sure, but she needed the sherds as well. Take the sherds away and her professional status would rapidly dwindle" (VAN REYBROUCK. D.; JACOBS D., 2006:37).

Na seqüência, a percepção indígena sobre o regime de verdade se media pela noção de autoridade. A autoridade do cientista colocada no mesmo patamar que a autoridade do cacique, ainda que feito em tom jocoso.

JovemKaiabi1: Opinião de arqueólogo...

JovemKaiabi2: Não é opinião de cacique não né, Arqueólogo2? (risos)

Essa aproximação do olhar indígena reflete, na verdade, a dificuldade no estabelecimento de um diálogo entre pesquisador e pesquisado (ainda que mediado pelo artefato) e, até mesmo, aspectos colonialistas da ciência. Mesmo que o arqueólogo tente problematizar essas percepções, elas se encontram tão enraizadas no olhar indígena que causa surpresa e comoção um branco interessado na sua cultura para além dos aspectos exóticos do senso comum. Ao mesmo tempo, é difícil para um cientista, acostumado com os regimes da verdade da ciência, valorizar e incentivar um regime de verdade indígena diferente do seu, ainda que se parta do

procedimentos imediatos para amanhã, abrir outras quadras na estrutura está descartado?

Arqueólogo4: estamos discutindo.

Arqueólogo3: Acho que se for para mexer na estrutura, realmente seria para acharmos alguma coisa para a datação em TL e eventualmente uma amostra melhor de carvão. Arqueólogo4: Agora não podemos descartar a possibilidade de preservar ela e no final do campo concluir a escavação na estrutura.

Arqueólogo3: Mas será que assim sobra tempo? Nos outros sítios teremos que ser rápidos.

Arqueólogo2: Esse que é o negócio, estamos optando por seguir o planejamento corrido do arqueologo5, que é fazer todos os sítios com sondagem, coleta de superfície, registro, fotografia, descrição e etc. Acho que você deve nos usar, Arqueologo4, para o trabalho que você não consegue fazer sozinho, que é o trabalho arqueológico de fato, o trabalho com o sítio. É nisso que podemos te ajudar.

Arqueólogo3: Concordo.

Segundo momento, durante o café-damanhã

JovemKaiabi1 : Pela manhã na estrutura do sítio, está fácil de tirar aquele material, mas pela metade...

Arqueólogo2: Não queríamos tirar ela pela metade, queríamos escavar a estrutura inteira.

JovemKaiabi1: Vocês que mandam...

Arqueólogo4: A discussão é porque nós também temos que cumprir o planejamento da pesquisa e trabalhar em outros sítios. A 
mesmo objeto, o artefato. Tarefa mais árdua ainda é a de se colocar os regimes de verdades como equivalentes, no sentido ontológico, projeto da Antropologia/Arqueologia Simétrica.

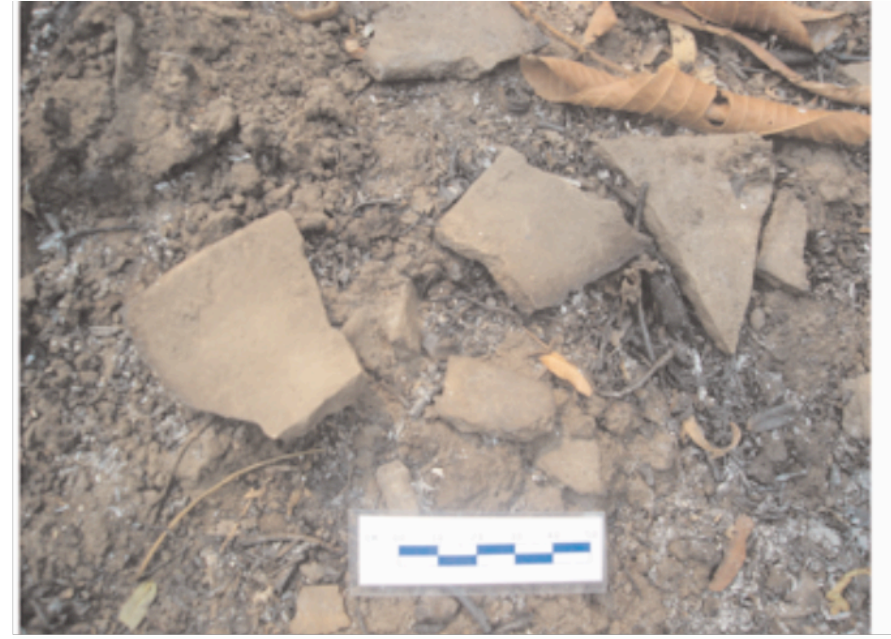

Foto: Francisco Stuchi

Fragmentos cerâmicos no sitio Dinossauro
Expressões sobre percepção temporal

Nas entrevistas, é
especialmente interessante a
noção de tempo embutida nas
narrativas. Discutir a natureza do
tempo em um determinado
contexto tradicional é importante
para reflexões sobre

ancestralidade, concepção de história, instabilidade e fluidez de fronteiras temporais e esquecimento (no sentido da seleção de memória a ser transmitida), que são condições para a invenção de um conhecimento tradicional (LENCLUD, 1994, HOBSBAWM, E. \& RANGER, T., 1994). Invenção esta que tem reflexo na cultura material local, nos processos de transformação da cultura material.

preocupação é que se começarmos a escavar a estrutura e abrir novas quadras para isso, poderemos perder muito tempo.

JovemKaiabi1: Mais ainda falta muito tempo para vocês irem embora...

Arqueólogo3: Mas nosso tempo já se esgotou no sítio dinossauro.

Arqueólogo4: E aí o que nós fazemos?

Arqueólogo2: Lá no sítio falamos com todo mundo.

JovemKaiabi1: Eu não sei de nada, quem sou eu para falar alguma coisa...

Arqueólogo2: Você é o cara que faz parte da comunidade, que vem todo dia na nossa casa e, além disso, você trabalha conosco.

JovemKaiabi1: Eu posso falar, vamos escavar tudo e tirar aquele material. Porém, são vocês que mandam...

Arqueólogo2: Mas essa é uma das hipóteses, nós temos duas escolhas ou escavamos a estrutura inteira, ou jogamos uma lona nela e enterramos de volta para daqui um ano, dois ou três anos voltamos para escavarmos, quando sair outro projeto de pesquisa.

Arqueólogo1: Ou a estrutura fica de exemplo de trabalho arqueológico para vocês.

JovemKaiabi1: É. Só que o problema de vocês..

Arqueólogo2: Exemplo de trabalho arqueológico incompleto, não concluído! Já que não sabemos o que é aquilo.

Arqueólogo3: Temos vários outros lugares para visitar.

JovemKaiabi1: É porque se escavarmos mais a estrutura, isso irá demorar.

Arqueólogo3: E nos outros lugares, que a princípio está programado de abrirmos só um poço-teste, uma quadra, e se encontramos 
JovemKaiabi1: Eu sempre perguntava pro meu pai: 'como que antigamente caraíba [o branco] era? Quem foi o primeiro a ver?'. Ele foi contando, contando....ai acabou a história, vinha outra. Como vocês brigavam antigamente, por quê?

Então como que era antigamente, o jovem era casado com o mais velho ou mais novo? E ele explicava.

Arqueólogo1: E como que é?

JovemKaiabi1: Antigamente o jovem que nem eu não casava com mulher nova, casava com uma mulher de mais ou menos 40 anos. Ela que explicava as coisas pro jovem. A mulher jovem não casava com novo, casava com mais velho, e ele que tinha o direito de orientar, de ensinar. A mãe dela também tinha esse direito. Por exemplo, se ele mandar a mulher nova fazer um mingau, e ela não souber, ela tem que correr pro rumo da mãe para ensiná-la.

E complicado também a história, se ela está sentada com o sogro, ela não pode passar na frente do sogro, tem que passar por trás. Essa era a lei do Kaiabi.

Que nem eu falei, tem história [regras] pra respeitar, tem história de casamento, tem história pra entregar comida.

É muita coisa, tem a história da planta, da roça, de como que tira, da coleta. Tem a história de peixe, de sapo, de gavião ... muitas coisas.

Arqueólogo1: E a história dos cacos cerâmicos?

JovemKaiabi1: (risos) tem vários....mas é como eu te falei, eu não tenho muita experiência em contar várias coisas, o que eu gravei é o que eu conto, o que eu não gravei, quer dizer, o que eu tenho dúvida, tenho que perguntar (para os mais velhos).

uma beirada de estrutura que nem essa do sítio dinossauro?

JovemKaiabi1: Ai, eu que escolho o lugar da escavação. (risos)

Que nem eu falei, no sonho do outro índio (auxiliar de campo) ele viu que tiramos uma coisa interessante debaixo da terra. Eu também sonhei que aquilo era um cemitério, que tinha muita coisa bonita. Por isso que ontem conversávamos no idioma kaiabi com os outros auxiliares de campo, falávamos sobre nossos antepassados e que vocês vêm trabalhar e nós vamos acompanhando as coisas. Que ao invés de sermos nós que mostramos as coisas de antigamente para vocês, são vocês que mostram para nós. Achei isso interessante. É bonito. Eu mesmo nunca vi cerâmica que kaiabi fazia.

\section{Terceiro momento, no sítio dinossauro.}

Arqueólogo4: Aqui chegamos numa situação bem interessante, nós encontramos uma estrutura e ao que parece ela continua para os outros lados da quadra. Nós, arqueólogos, ficamos discutindo ontem à noite, e ficamos com uma dúvida dentro da nossa programação. Perguntamos-nos se devíamos ficar mais alguns dias abrindo mais quadras, trabalhando na estrutura ou se encerramos por aqui. Protegemos a estrutura com uma lona, e voltamos em um outro momento para terminar, assim mantemos o tempo de trabalho nos outros sítios. Levando em consideração que nos outros sítios, programamos de trabalhar em um dia, mas poderá levar mais do que um.

A equipe de arqueólogos dispensou o tempo 
Que nem os furos que vocês estão fazendo, eu fiquei com dúvida e perguntei pra o cacique.

Arqueólogo1: O que ele falou?

JovemKaiabi1: Perguntei se esses lugares [sítios] de antigamente eram de Kaiabi mesmo. E ele disse que era de Kaiabi mesmo, mas também de outros parentes (índios) que vinham de baixo [do curso do rio] e ocuparam esses lugares. Mas eu tenho muita pergunta principalmente dessa cerâmica, porque lá onde a gente viu muito no sítio Dinossauro eu tenho muita dúvida. Porque a única aldeia que meu pai nunca contou é aquela do Dinossauro, pois sobre o Caititu e outras ele já tinha me contado, mas nunca fui visitar.

Arqueólogo1: Ele contou o que?

JovemKaiabi1: Contou que essas aldeias eram Kaiabi, ele contava o nome dos pais dos índios que moravam lá, mas é muita coisa na cabeça da gente que tem que botar no papel. É assim que quero fazer com o meu pai, passar todas as histórias no papel. A história que ele mais contava era da aldeia Batelão, lá no rio dos Peixes. Ali ele conta história, mas nem eu ou meus irmãos conhecemos o lugar.

Arqueólogo1: Que história ele contava?

JovemKaiabi1: De lugar que ele conhece e de lugar que a gente não conhece. Que nem eu falei pro estudante de antropologia que pesquisa na área, pra você ter história de verdade mesmo, você tem que ir para o Xingu. É lá que você vai encontrar a história original mesmo, lá que você vai encontrar as pessoas que moraram, as pessoas que andaram demais nesse rio. A idéia nossa é de trazer esses velhos aqui, só para ouvir as histórias deles pra gente passar para outras pessoas, pra quem tem

de folga que possa ter, já que o tempo de trabalho nos sítios será maior do que o previsto.

Gostaríamos de saber o que vocês acham mais interessante, se devemos abrir mais quadras para escavar toda a estrutura ou deixamos para terminar em um outro momento, já que temos outros lugares para trabalhar.

Arqueólogo2: Vocês entenderam? O previsto era trabalhar em vários sítios além deste, claro que nos outros não trabalharíamos como estamos trabalhando neste. Bom, aqui apareceu esta estrutura, para escavarmos, precisaríamos trabalhar em mais três quadras. Pode ser que ela seja pequena, mas pode ser que ela seja maior e na medida em que escavemos podem aparecer mais coisas. Então temos que decidir se deixamos ela como está ou se deixamos de ir a alguns sítios para terminamos de escavar essa estrutura. Não adianta escavarmos só o que apareceu e deixarmos o resto. Temos a opção de esperar a próxima vez que o arqueólogo4 voltar aqui com uma equipe para escavar, que pode demorar mais dois ou três anos. Não é sempre que ele tem uma equipe para escavar um sítio. Então essa é nossa grande dúvida, queríamos ouvir o que vocês têm a dizer. Se devemos evidenciar essa estrutura e gastar mais tempo aqui ou se voltamos a escavar em outro momento que pode ser daqui um, dois ou três anos. Essa é a grande questão.

Arqueólogo1: Seria interessante falarmos também o porquê de cada opção, de cada escolha que poderia ser feita. Um dos motivos de trabalharmos em diferentes sítios era já que o arqueólogo4 conversou com diferentes pessoas da comunidade então teria que passar 
interesse quiçá fazer um livro de histórias.

Vários velhos já morreram, e só alguns que estão sobrando. Por isso que os professores não-índios, acompanham esses velhos lá no Xingu, já que está acabando esse pessoal que conta a história original. Você vai entrevistar um rapaz de 40 anos ele vai contar uma história, mas foi o velho que passou pra ele. Ninguém sabe de hoje pra amanhã como vai ser, sempre perdemos uma peça de valor, uma pessoa que sabe contar a história. $O$ ano passado mesmo, perdemos um cara que sabia contar muito bem a história de Alta Floresta, muita gente aproveitou a história dele. Porém, muito do que ele contou o pessoal não aproveitou.

Arqueólogo1: E a história do branco?

JovemKaiabi1: A história do branco é que eles chegaram brigando. Se o seringueiro estava tirando seringa do cipó, nos chegávamos e víamos os rastros no caminho. "Ah ai passou um seringueiro", nós matávamos ele ou quando estava no seringal ou quando dormia. O que a gente observa é que os Kayapo, Parana e Kaiabi eram os que matavam mais entre índios e branco. Meu pai tem uma história também que ele acompanhou os guerreiros dele para matar um seringueiro que estava tirando mel.

Assim é possível demonstrar o acionamento histórico que os objetos arqueológicos suscitam na memória dos Kaiabi (e na dos Terena, da aldeia Lalima), que, de forma reflexiva, nos questiona sobre a maneira como encaramos o pensamento histórico na nossa sociedade em comparação com a versão histórica dos coletivos da T.I. Kaiabi (e Lalima) articulada na sua própria cosmogonia. Portanto, a análise do vestígio arqueológico vai para além do contexto político de demarcação,

em diferentes lugares da Terra Indígena Kaiabi para mostrarmos o que é o nosso trabalho. Perdemos mais tempo aqui significa não passarmos mais em outros lugares. Do meu ponto de vista, existe uma terceira escolha. Que é preservar a estrutura tal qual ela está, como demonstração do trabalho de arqueologia que é feito aqui. Porque, terminar essa escavação significa recolher o material da estrutura, tirar daqui, e levar para o museu. Esse material não vai ficar na terra dos Kaiabi. Vocês têm a escolha de querer que o material fique aqui. De querer mostrar para as pessoas da aldeia que existe essa estrutura aqui. Isso é uma outra escolha possível.

Arqueólogo2: Uma outra coisa é verdade, nós não sabemos o que é essa estrutura. Talvez nem seja uma estrutura funerária ou algo do tipo, talvez seja só um amontoado de cacos.
Isso só descobriria escavando. Além disso, em termos educativos, provavelmente $\mathrm{o}$ arqueólogo4 irá fazer um projeto. Deve ter centenas de outras estruturas como essa daqui, a questão é de acharmos elas. Em termos educativos o que vocês só vão poder falar é que a estrutura simplesmente existe, mas não vão saber que vasilha era esta, como que isso ai foi feito. Escavar a estrutura é entender como ela foi feita, como ela foi formada.

Diretor da escola: Será que ela está mais pro fundo ainda?

Arqueólogo2: Acho que não, pois quando aparece esse solo laranja é porque é o limite do sítio.

Arqueólogo3: O problema é que ela vai pro lado.

Diretor da escola: Porque se fossem deixar mais dois ou três anos ai... eu não queria. Pois 
dos laudos antropológicos ou dos aspectos científicos positivistas. O vestígio é um elemento chave para o acionamento da memória cultural, compartilhada coletivamente Contudo, o sentido político não desaparece, a sua tonalidade entra em confluência com a dinâmica própria de percepção cultural nativa (CARNEIRO, 2004). Esse, inclusive, é um elemento chave para se entender a polêmica social em torno das hidroelétricas (e laudos arqueológicos) nos arredores do Parque Indígena do Xingu. Portanto, a atividade arqueológica junto a populações tradicionais deve levar em consideração aqueles que não costumam serem ouvidos no mainstream acadêmico. Não apenas para outras interpretações sobre o passado, mas também sobre a influência que outras vozes exercem em uma pesquisa realizada no presente. Se no trabalho de Nadia Abu El-Haj (1998), em Jerusalém, ela verifica a criação de uma cultura material pelos próprios arqueólogos no teor de reificação da dominância social, em alguns casos - como creio ser o caso Kaiabi - a cultura material criada pelo arqueólogo, no sentido das percepções que são esboçadas num contexto social frente aos objetos escavados, se alinha com a política de contestação indígena ( em especial a luta pela terra) e, como não poderia deixar de ser, se alinha também a uma memória cultural nativa.

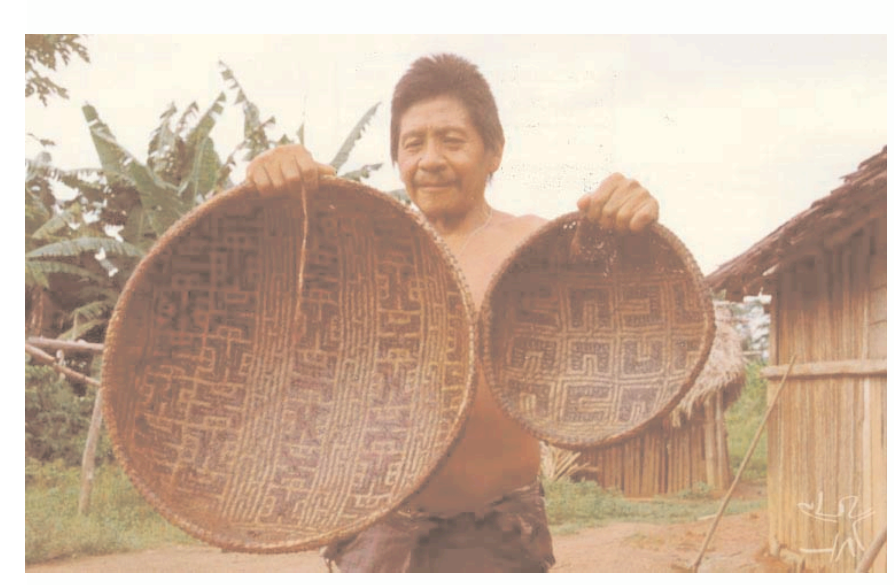

Foto: Georg Grünberg Cestaria kaiabi

\section{Agenciamento dos objetos}

Antes de nos aprofundarmos no caso etnográfico dos Kaiabi, vale à pena esboçarmos um pouco mais sobre os princípios norteadores de agency em arqueologia, que segundo Márcia-Anne Dobres e Robb (2000) podem ter raízes em dois princípios marxistas que são refletidos em alguns elementos da prática contemporânea de arqueologia: vai interditar a minha área de plantação. Essa é uma região que ia fazer uma derrubada.

Arqueólogo2: É uma coisa para se pensar também. Então, em sua opinião você preferiria que ela fosse desmontada?

Diretor da escola: É. Porque tem outros interessados em plantar nessa área, até mesmo os meninos que estão trabalhando aqui.

Cacique: É porque vão jogar pau em cima e vai quebrar tudinho.

Jovemkaiabi3: Vão plantar banana ai e vai quebrar tudinho ( risos).

Diretor da escola: Se for escavar no ano que vem ou agora mesmo, eu estou disposto. Porém, se ficar para dois ou três anos, aqui vai ficar uma área impedida. A roça já está aqui ao lado, portanto, a minha preferência é derrubar o mato dessa área (onde está a estrutura).

Arqueólogo2: É uma coisa para se pensar. Escavar aqui não é fácil. Não é sempre que poderemos vir aqui. São necessários muitos recursos para escavar. Vocês entendem isso, né? Uma outra coisa, é claro que vamos trabalhar em outras aldeias e conversar com outros Kaiabi, mas se formos sacrificar um 
"Indeed, the roots of of contemporary pratice theory can be traced back to two of Marx's most of quoted passages:

Men (sic) make their own history, but they do not make it just as they please, they do nor make it under circumstances chosen by themselves, but under circumstances directly encountered, given and transmitted from the past (Marx 1963:15 (orig.1869)) As individuals express their life, so they are. What they are, therefore, coincides with their production, both with what they produce and with how they produce (Marx and Engels 1970:42)

All of the core elements of contemporary practice theory are here:

- Society is a plurality of individuals who exist only by virtue of the relationships they create during everyday material production (praxis).

-Humans produce their cultural histories through praxis, which highlights the processual nature os social reproduction

-Individual (or group) free will and volition are explicitly disavowed, in part because people do not choose the conditions within which they live.

-These structural conditions have a strong material basis

- Institutional settings and conditions constitute a material world that is made, experienced, and perceived (that is, symbolized and made meaningful) by those living in it (which prefigures agency theories of embodiment)

-Society exist as the result of antecedent conditions, which gives time and history prominent roles in shaping social formations and the particular practices constituting them." (DOBRES; ROBB 2000: 5)

local, pode ser aquele que não tiver ninguém morando. Se o caso é de mostrar o trabalho arqueológico para os Kaiabi, podemos deixar de ir nesses locais desabitados.

Arqueólogo4: O que o Diretor da escola falou já seria motivo suficiente para escavarmos, mas seria importante conversamos mais alguma coisa. Alguém quer falar mais alguma coisa?

Arqueólogo3: Acho que é isso. Trabalharmos pela metade não adianta e para trabalharmos direito teríamos que abrir mais três quadras, vai demorar mais tempo e talvez não conseguíssemos ir para os outros lugares. E você quer liberar a terra.

Cacique: E não adianta deixar lona em cima, que pode vir outro e estragar tudo. Se entrar um pedaço de pau na quadra pode quebrar tudo.
Arqueólogo1: Lembra ontem quando assistíamos o DVD com vocês? Tinha uma parte que falava sobre arqueologia. Isso no mundo do branco, fazer trabalho de arqueologia, é um imaginário muito grande, existe muita curiosidade.

Pensando pro futuro...tudo bem, entendo que aqui é a sua área de roça, mas também penso na comunidade como um todo, mas aí vocês terão que dar a opinião também, em relação a isso. Aqui é um sítio que vocês podem preservar por muitos anos e se vocês tiverem um projeto de turismo ecológico é uma coisa que pode ser utilizada.

Arqueólogo2: Os sítios arqueológicos não vão fugir, eles vão continuar dentro da área, vocês não vão perder. Pelo contrário, a minha opinião é quevocês vão ganhar em conhecimento com a escavação desta 
Para uma primeira abordagem do caso etnográfico temos que lembrar alguns autores em arqueologia que trabalham com poder social trazido pela relação entre artefatos-pessoas, tais como Appadurai (1986), Meskel (2004), Schiffer e Miller (1999), Holtorf (2002), Edgeworth (2006). Eles destacam que os artefatos possuem uma centralidade nas ações humanas e que o poder social advindo da relação pessoaartefato problematiza categorias ocidentais das análises sócio-culturais.

Um dos benefícios do trabalho etnográfico é descobrir um pouco mais sobre o que exatamente os arqueólogos estão fazendo quando estão 'descobrindo o passado', como eles transformam certas coisas em evidência arqueológica?

Um arqueólogo em campo tem sua interpretação limitada não apenas pela sua formação intelectual e experiência, mas também pelas técnicas disponíveis e por normas e valores do discurso acadêmico (HOLTORF, 2002).

Assim, o que faz o conjunto de cerâmica descoberto no sítio Dinossauro tão importante aos olhos do arqueólogo? Ora, como podemos perceber nos diálogos, é o agenciamento do objeto (no caso, o conjunto cerâmico) que é mobilizado, ele fomenta e articula a ação humana em torno dele (agency); aspectos valorativos (grande ou pouca importância arqueológica) são mobilizados, fatos científicos são construídos e a formação arqueológica em cada pesquisador é reificada (VAN REYBROUK; JACOBS, 2006).

Poderia ser uma situação similar como qualquer outra atividade de escavação, se não fosse por um aspecto. A escavação mobilizava um agenciamento diferente em torno dela. O olhar indígena.

estrutura, com a datação dela, com a análise do material, com o desmonte dela. Vocês vão ganhar em conhecimento. Existem outras estruturas como essa não só neste sítio, como em outros também.

Diretor da escola: Não impede em nada se taparmos a estrutura com lona e terra? E fazermos roça em cima? O fogo não estraga? Arqueólogo3: Pode ter algum problema, a terra está muito rasa.

Cacique: A raiz pode se queimar próxima do material.

Diretor da escola: Pro ano que vem vocês ainda podem preservar ela?

Arqueólogo3: É como você esta falando, se for usar mesmo para roça... A chance de voltarmos aqui é pequena.

Arqueólogo4: Se vocês não usassem para roça...
Diretor da escola: poderíamos reservar esse pedaço.

JovemKaiabi1: Dá pra fazer roça em outro lugar, aqui poderia ficar como Parque Nacional Arqueológico.

Arqueólogo2: È possível.

Arqueólogo4: Para vocês é importante que trabalhemos em outros lugares?

JovemKaiabi1: É importante para saber se tem material arqueológico, para conhecermos. É como eu falei para ti, quando eu trabalhei com vocês a primeira vez, achei que esse material não valia nada. Mas depois que eu entendi o que era... eu mesmo não conhecia a cerâmica do Kaiabi.

Arqueólogo3: Tem uma outra coisa, como falávamos hoje de manhã, que é o seguinte, se não escavarmos a estrutura até o fim e quando formos em outros lugares $\mathrm{e}$ 
Como uma caixa-preta que se abre, entraves, valores, políticas, polêmicas e até mesmo visões de mundo foram esboçadas em torno da estrutura arqueológica, justamente pela presença do olhar indígena. O que foi possível observar (ainda mais se contrastarmos as duas experiência etnográficas) é que no trabalho etnoarqueológico, a intensidade da abertura dessa caixa-preta em campo varia, não somente pela diferença entre etnias, mas também pela disposição do cientista em tornar a relação mais simétrica. Mesmo em outros estudos sobre etnoarqueologia no Brasil (POLONI, 2008, POLITIS, 2002), a interface entre pesquisador e pesquisado nunca é explorada em termos epistemológicos. O discurso comum sobre 'a importância de se trabalhar com indígenas, socialmente oprimidos' prevalece. Não que o debate sobre descolonização da prática arqueológica não seja importante (LAYTON, 1994b; SILLIMAN, 2005; LILLEY, 2006), mas para se entender como a práxis é desenvolvida e reificada, o olhar epistemológico é fundamental, até mesmo para uma verdadeira descolonização da própria prática.

Voltando às nossas caixas pretas, o que elas revelam de fato é a rede mobilizada, o agenciamento social feito por arqueólogos, companheiros indígenas e artefatos que podem ser traçados. É a actor-network-theory, ANT, esboçada anteriormente.

É importante lembrar que essa perspectiva reflexiva focada na relação entre pessoas e artefatos é desenvolvida na teoria social por autores como Alttfield (2000), Buchili (2002), Gell (1998), Latour (1994; 2000) Meskell e Preucel (2004), Miller (1987, 2005), fundamentados na noção moderna de agency, desenvolvida por Giddens (1993) e Bourdieu (1984).

encontrarmos algo parecido também não poderá escavar até o fim. Pois teremos pouco tempo, mesmo que não gastemos muito tempo aqui, se encontrarmos alguma coisa em outros lugares, vamos ter que parar com aqui. Portanto, alguma coisa pela metade vai acabar ficando.

Arqueólogo4: A minha preocupação é quando viemos fazer o primeiro levantamento dos sítios, conhecemos várias antigas aldeias e algumas atuais, e fizemos uma programação de trabalho. Essa programação pode ser mudada, mas por enquanto só dois arqueólogos da equipe, e os índios que nos acompanharam, é que conheceram esses lugares. A minha preocupação era de não conseguir mostrar para os outros arqueólogos esses lugares e não pensar junto com eles, quais os lugares que serão prioritários. Queria saber de vocês, o que vocês acham dos outros lugares que iremos trabalhar. Se é importante trabalharmos em outros lugares?

Cacique: Fazer o reconhecimento das aldeias que você escolheu?

Arqueólogo4: pelo menos nas aldeias que escolhemos, trabalhar o quanto for possível.

Arqueólogo2: podemos escavar mais dois ou três dias e evidenciamos a estrutura inteira, assim liberamos a área para vocês fazerem a roça. De qualquer jeito não iremos conseguir ir em todos os sítios que foram programados. Vocês viram como que é o trabalho. Não é simplesmente chegar ao sítio e trabalhar. Todo o sítio vai ser a mesma coisa, iremos parar, olhar o sítio, depois discutir sobre ele, todo mundo vai participar da discussão e ai que veremos como irá ser o trabalho. Só isso vai levar todo um dia. 


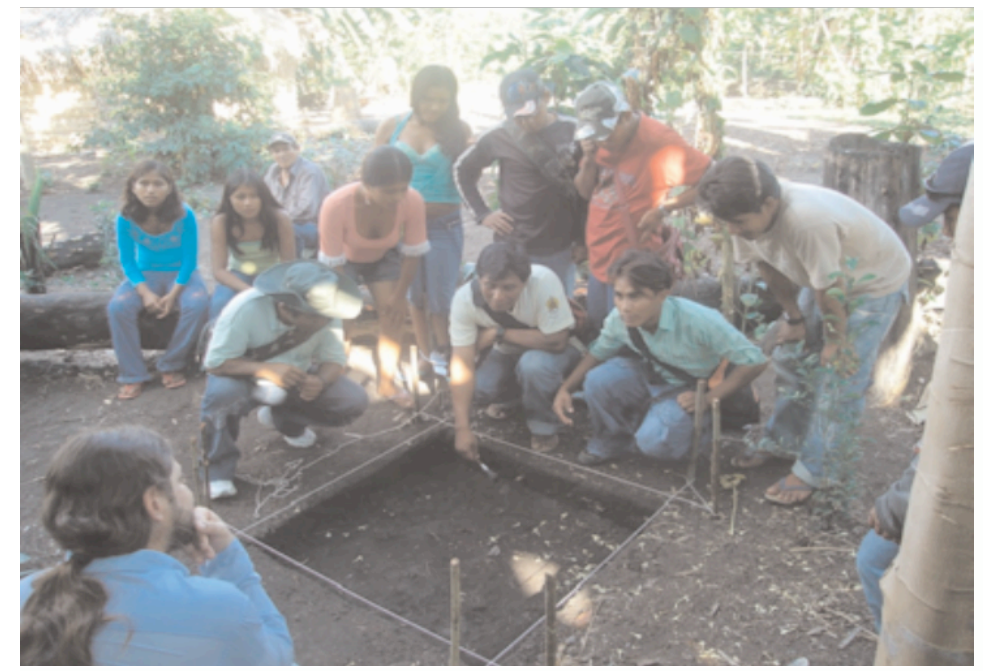

Grupo de estudantes da etnia munduruku em visita ao sitio arqueologico.
“Conhecimento para quem?"

Essa pergunta clássica da sociologia, muita vezes é desconsiderada nos trabalhos de ciências humanas - em tempo, considero a arqueologia como ciência social. Diversos motivos levam a tal posicionamento, seja por uma pesquisa diferenciada preocupada com questões mais 'técnicas', ou até mesmo a irrelevância de tal questão. No entanto, antes

de seguirmos para uma vertente política da arqueologia, tal como se considera a Public Archaeology no Brasil (FUNARI, 2001; FUNARI, P. P. A.; ROBRAHNGONZALEZ, 2007) prestemos atenção na potencialidade da geração de conhecimento trazida pelo artefato tanto na perspectiva arqueológica quanto indígena. No caso Kaiabi, a polêmica de tal pergunta "conhecimento para quem?" entre arqueólogos ('primeiro momento') revela a perspectiva e expectativa de conhecimento que deverá ser gerado em torno do artefato. Como as vasilhas forma feitas? Como a

Arqueólogo1: Mas quanto mais sítios formos melhor será.

Arqueólogo2: Eu não sei, talvez deixar de registrar um ou dois sítios para terminar a estrutura nesse sítio seja melhor. Essa é a minha opinião de arqueólogo!

JovemKaiabi1:Opinião de arqueólogo...

JovemKaiabi2: Não é opinião de cacique não né, Arqueólogo2? (risos)

Arqueólogo1: $\mathrm{Na}$ minha opinião de antropólogo... (risos)

JovemKaiabi2: e o Arqueólogo3?

Arqueólogo2: E a sua opinião de arqueólogo, Arqueólogo3?

Arqueólogo3: (risos) Então, não sei. A estrutura foi a coisa mais interessante que encontramos no sítio até agora, só que não sabemos o que é isso. Não sabemos se é um vaso que estava ai, se era uma pessoa que estava enterrada, se tem mais coisas nas quadras adjacentes. Não sabemos de nada, só iremos saber se escavarmos. E isso irá levar mais tempo.

Arqueólogo2: Arqueologia é isso! Arqueologia é escavação, é coleta de material, análise do material, datação...

Arqueólogo1: É isso, mas não é só isso. Tudo depende de como o arqueólogo4 trabalha com o vestígio

Arqueólogo2: O trabalho que o arqueólogo4 faz aqui tem que ser um parâmetro, para ele poder comparar com outros sítios. Acho que mesmo dentro da perspectiva do arqueólogo4, arqueologia não deixa de ser arqueologia.

Dentro da perspectiva dele seriam obtidas informações bastante interessantes para ele mesmo, se a estrutura fosse escavada, fosse compreendida. 
estrutura foi feita? Foi quebrada? Qual a datação em termo-luminescência? Existe amostra de carvão? É uma estrutura de funerária? Enfim, é todo um regime de verdade científica que pode ser realizado, empiricamente, pela arqueologia.

Na perspectiva indígena, é importante considerar o aspecto mnemônico que o artefato pode ter, assim como desenhos, grafismos corporais e outros padrões ornamentais indígenas (MULLER, 1990; RIBEIRO, 1986; VIDAL, 1992). O enlace com a memória indígena se dá através da sua cosmogonia, que pode seguir caminhos sinuosos, que podem fugir da lógica de pergunta-resposta, própria de uma pesquisa científica.

As abordagens etnográficas e etnoarqueológicas nos fornecem algumas pistas desse processo (SILVA, 2002, DIAS et al, 2008). Na leitura etnográfica, as narrativas kaiabi são centradas na sua tradição guerreira, na sua auto-imagem enquanto grupo étnico (TRAVASSO, 1993) celebradas não só nos seus rituais e cantos, tais como o yawaci ou dzawaci, como também nos motivos dos desenhos de suas cestarias (RIBEIRO, 1986). Esta tradição guerreira, como sugere Travassos (1993) na análise dos trabalhos de Karl Von Den Steinen, possuem relação com o monopólio e fabricação dos machados de pedra. "Vieram os caiabis, vizinhos dos bacairis do Paranatinga, os quais, pelo que nos foi relatado, outrora mantinham com eles relações pacíficas, mas que, devido aos machados de pedra e às mulheres, se tornaram seus inimigos mortais" (STEINEN, 1940:479). O mesmo Steinem e depois Schmidt (1993, 1942), segundo Travassos, reconhecem os machados de pedra kaiabi como principal elemento das suas redes de troca, depois substituídos pelos instrumentos metálicos, também motivadores de guerra.

\footnotetext{
Arqueólogo4: O que pensei foi que não só os arqueólogos pensassem. Agora temos mais cabeças para pensarmos juntos. Pensei que devemos parar por aqui temporariamente. Para que eles conheçam as outras aldeias. Ai pensamos juntos se vale a pena trabalhar em outras aldeias ou terminar essa estrutura. Quanto mais opinião, melhor.
} 
"A substituição progressiva dos machados de pedra é um marco na historia cultural do grupo. Schmidt (1942), que esteve com os caiabis do PI Pedro Dantas em 1927 soube que eles passaram a distribuir também os instrumentos de ferro entre as tribos vizinhas, tal como faziam antes com as pedras, o que atesta a importância destes itens no circuito de trocas dos caiabis, fossem elas realizadas por meios pacíficos ou não."(TRAVASSOS, 1993:457)

Mais do que isso, os machados estão presentes na circulariedade cosmológica. Em campo, um dos informantes, João Kayabi, contou-me a seguinte situação: Quando acontece um temporal e se escuta um trovão, deve-se dizer "ape'yp, ape'yp wuu pype nipo enejy po'om sare'já!"

ape'yp=um tipo de madeira

Wuu $=$ ele + grande, muito ou grosso (na tradução de João)

Pype $=$ dentro de

Nipo=indica incerteza.

Enejy=machado

Po'om=atolar

Sare'já= Infelizmente+rachar/partir)

(Fonte:Weiss, Helga Elisabeth. Para um dicionário da língua Kayabí Tese de Doutorado São Paulo, 1998.)

Segundo João, essa expressão vocativa, de difícil tradução, é direcionada ao espírito do vento, para que ele se acalme. O que se pode fazer também para acalmar o senhor dos ventos é imitar o passarinho uru'i . Como ele é um pássaro fraquinho, o senhor dos ventos fica com dó e desvia o vento. Podemos perceber que existe uma conexão cosmológica com ape'yp, o machado e o senhor dos ventos. A importância do machado já foi descrita acima, já o ape'yp tem uma importância fundamental na fabricação ceramista das panelas tradicionais. São poucas as pessoas que se lembram do processo de fabricação, seja pelo uso das panelas metálicas (VILLAS BOAS; VILLAS BOAS, 1989) ou porque, segundo o informante de Berta Ribeiro, Tawãpa Kayabi, "respeitam o que os outros fazem" (no caso, respeitam os Yudjá (juruna) que são um grupo ceramista do Parque Indígena do Xingu) (RIBEIRO,1986:284).

O ape'yp é o tempero específico no processo de fabricação das panelas. Os irmãos Villas Boas já mencionavam a especificidade de um tempero na confecção das panelas "o barro apropriado, misturado com pó de carvão obtido da casca de determinada árvore" (VILLAS BOAS ;VILLAS BOAS, 1989:60). No entanto, foi Dona Rosa Kaiabi que me contou qual tipo de casca de arvore que era usada. "Usa a casca de pau, na língua (kaiabi) é ita ape'yp , que é 'o tempero da panela'. Queima todinho a casca, depois mói e põe misturado com o barro"10.

No entanto, só com uma etnografia mais aprofundada seria possível descobrir as especificidades da relação de ape'yp com o espírito dos ventos (ou

\footnotetext{
${ }^{10}$ Ita, significa pedra, que é como aparece o tempero nas panelas, pequenas pedrinhas de carvão.
} 
uma possível equivalência com a entidade sobrenatural anang, descrita por Ribeiro). O que é certo é o efeito mnemônico descrito pelo artefato, o agenciamento e os processos culturais envolvidos na percepção indígena, como demonstra também Suzanne Oakdale sobre o herói mítico Kaiabi, Tujare, que criou os primeiros Kaiabi a partir de vários objetos e animais, tais como, por exemplo: água barrenta, mingau de mandioca, colares, corda, tucanos, raposas e onças (OAKDALE, 2005:164) que possibilita o acesso à dimensão espiritual com a mediação dos pajés:

"Shamans can also see the spiritual dimensions of common objects. Stone-Arm explained that when a shaman enters a house, where most people see normal objects such as mortars and pestles, baskets, and benches, a shaman often sees the souls of these things. The objects appear "like people"'. (OAKDALE, 2005:87)

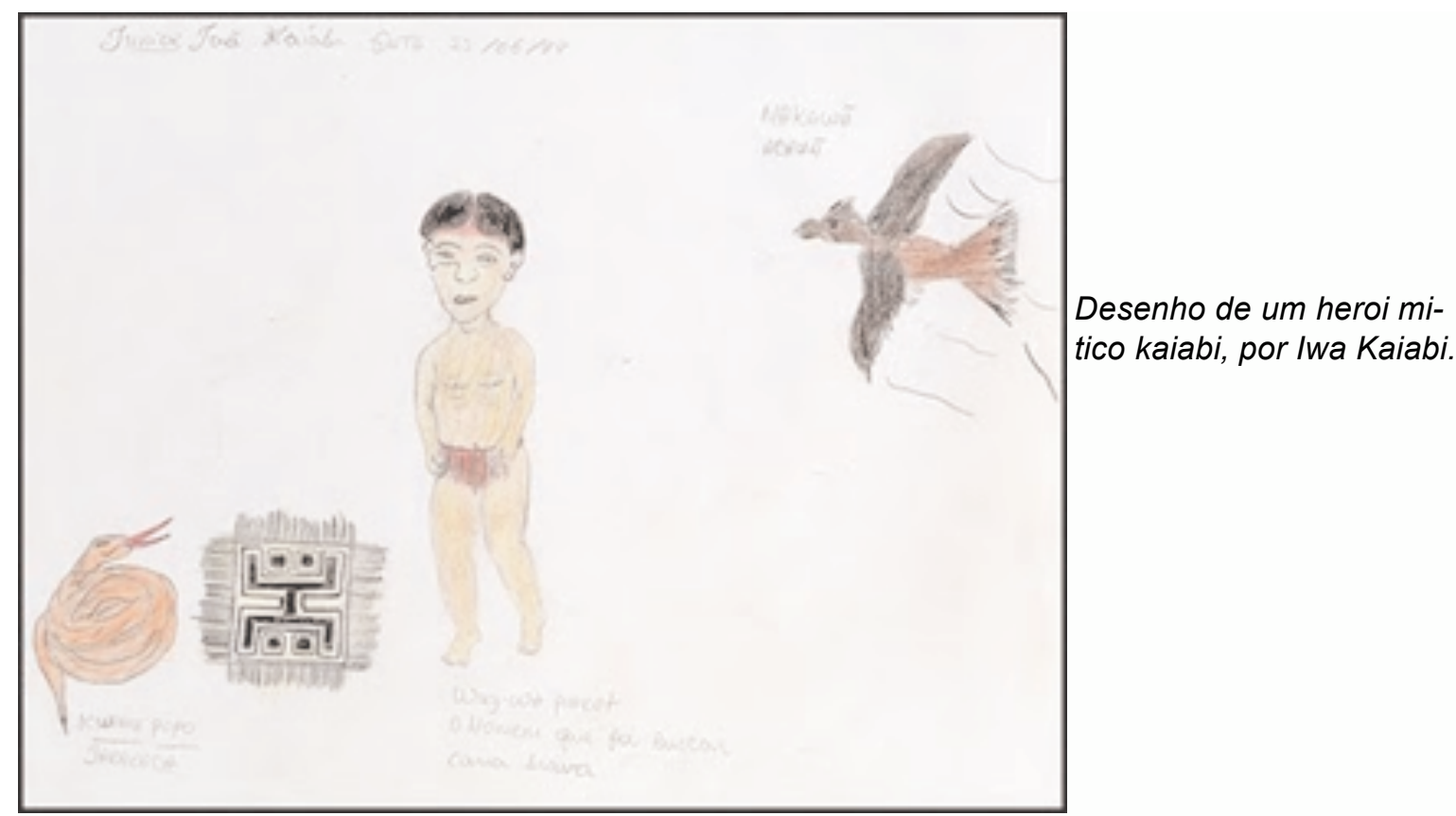

Novamente, a importância desses processos está no desenvolvimento mais aprofundado da etnoarqueologia e na própria epistemologia da disciplina arqueológica.

\section{Quando o objeto arqueológico atua na cosmogonia}

A atenção aos procedimentos de atribuição de verdades, nos processos de uma possível teoria do conhecimento indígena, possibilitou levar em consideração algumas informações que poderiam ser descartadas, seja por não possuírem correlatos bibliográficos ou confirmação oral. Por exemplo, na transcrição abaixo o Jovemkaiabi3 junto com o Jovemkaiabi1, que foram auxiliares de campo, nos contaram uma história sobre um aspecto do ritual de iniciação masculino associado à quebra de panelas não-kaiabi e os resguardos necessários relativos ao contato com coisas antigas. Apesar de não ter encontrado a confirmação da história da festa de iniciação em outros relatos, o contexto discursivo em que ela foi contada sugere uma apreensão de sentido ao artefato, além da marcação autobiográfica sugerida por Oakdale (2005). É importante dizer, portanto, que esse relato foi contado na presença de outros Kaiabi e, em nenhum momento, eles questionaram esse relato, apenas complementaram 
com mais dados.

JovemKaiabi3: Se um jovem mexesse num osso antigo, em cima de cemitério, tinha que se prevenir. Não pode comer castanha, amendoim e várias coisas porque senão pode ficar aleijado. Por isso que só os velhos mexiam com isso, os jovens nem chegam perto. Só em dia de festa, ai o pai escolhe que filho ele vai mandar para a festa [ritual de iniciação masculino]. Às vezes um jovem até inventa de ficar doente pra não ir...

JovemKaiabi1: Porque sofre muito, não é apenas dois ou três meses, são dois anos, quatro anos [de ritos de passagem e reclusão]...

JovemKaiabi3: Tira até dente de peixe pra arranhar o jovem no rito de passagem...

Aqueologo1: Como é que você dizia? O pai que escolhia o filho para quebrar panela? JovemKaiabi3: É.

Arqueólogo1: E ela era trazida de outras aldeias e nunca panela kaiabi. Por que não kaiabi?

JovemKaiabi1: Porque era dele. Como ele iria quebrar uma coisa que é dele, que é do Kaiabi? É como ele diz, uma pessoa traz uma panela pra quebrar de outro parente (outra etnia). Por exemplo, tenho uma panela munduruku e quero fazer uma festa. Ai eu sou o dono da festa, ai vocês vão me apoiar e combinamos o que vai acontecer com os jovens. Ai vocês comunicam com toda a aldeia sobre o que irá acontecer. $O$ pessoal chega na festa já sabendo o que irá acontecer. Os pais têm que conversar com os filhos antes para decidirem se eles irão enfrentar ou não (o rito de passagem). Que nem ele, diz muitos jovens não querem ir. O meu pai quis que eu fosse, mas eu não aceitei. Eu não queria sofrer. Não é fácil. Não é qualquer coisa.

Arqueólogo1: Quem passa por isso o que acontece?

JovemKaiabi1: Quem passa de 2 a 4 anos é o maior guerreiro

Arqueólogo1: Todo homem tem que passar pela festa?

JovemKaiabi3: É. Ali é que ele vai apreender a respeitar, apreender a fazer uma casa, uma roça. Ali é que ele se prepara para deixar de ser criança, para ser homem.

Arqueólogo1: E a panela só quebra uma vez?

JovemKaiabi3: Só um vez.

Arqueólogo2: E a panela é do inimigo.

JovemKaiabi3 É do inimigo.

Arqueólogo3: Isso era assim na época do pai, do avô de vocês?

JovemKaiabi3: É.

Arqueólogo1: Tinha panela também de etnia amiga, de aliada?

JovemKaiabi3: Não sei. A cultura do Kaiabi, era só de matar, não tinha amigo, não tinha amizade com ninguém.

Arqueólogo1: Pra conseguir a panela não tinha que fazer troca?

JovemKaiabi3: Não, era quando matava outro índio ou quando encontrava com um durante uma caçada. Índio não tinha área delimitada, toda mata era área de caça. Não tinha reserva marcada, então Kaiabi ia até território dos Apiacá, se encontrava eles, matava. Os Apiacá também vinham até aqui, então não tinha lugar certo. Então Kaiabi chegava até São Paulo e Rio de Janeiro, passava dois, três, cinco até 10 anos caçando. Guerreiro mesmo, ninguém se preocupava com ele. Passava um tempo, 
eles voltavam.

Arqueólogo1: Voltavam com coisas?

JovemKaiabi3: Voltavam. Às vezes traziam panela, às vezes traziam cabeças, às vezes traziam um nome. Uma tatuagem. A tatuagem registra o nome. Ele não usa mais o nome dele, usa nome novo da tatuagem.

Arqueólogo1: Os Kaiabi no Xingu ainda fazem panela?

JovemKaiabi1: Não fazem mais. O problema é o seguinte, as pessoas que sabiam foram se acabando, agora só tem algumas [peças] em São Paulo [no museu]. Também não tem material lá [no Xingu]. Os velhos são poucos. Alguns já não falam mais.

Arqueólogo3: Os jovens não têm curiosidade em perguntar?

JovemKaiabi3: Não, eles não têm interesse, principalmente aquele que estuda na cidade.

Arqueólogo4: Tem problema vocês tocarem nos fragmentos de panelas quando vocês trabalham conosco na escavação?

JovemKaiabi3: Não, porque hoje em dia muita gente não acredita mais.

Como diz o Jovemkaiabi3 no final do segundo momento da discussão sobre a estrutura, os Kaiabi conversavam a todo o momento no idioma kaiabi. Como mostrou o relato acima, um dos assuntos recorrentes foi o resguardo necessário no manejo das panelas antigas. Em uma das entrevistas finais com o Diretor da escola, podemos perceber um pouco melhor essa relação:

Arqueólogo1: O pessoal estava me contando que quando começamos a trabalhar na sua roça, você ficou com medo que seus filhos ficassem doentes, como que é isso? Diretor da escola: Não entendi?

Arqueólogo1: O pessoal me contou que você ficou com medo, quando começamos a abrir buraco, de mexer em panela antiga...

Diretor da escola: Ah sim, na verdade, não é que eu fiquei com medo, todo mundo ficou com medo, toda a equipe. Se nós pegarmos qualquer cerâmica, não aquele pedaço que está fora da terra, aquele pode pegar, mas aquele que está enterrado, não sabemos se foi deixado lá por alguém. Ou qualquer osso também. Isso para nós, não sei agora, mas para os antigos, se pegarmos aquilo lá, é danado para adoecer qualquer um. Ela dá aquela tal doença de reumatismo, dor em qualquer lugar no corpo que tem articulação. Na época, acho que a doença não tinha cura, e a pessoa não conseguia mais andar. Por isso que nós Kaiabi temos medo dessas coisas. Para pegar essas coisas tem que se cuidar se curar com raiz do mato. Toda comida tem que ser certa, não podemos comer qualquer comida, só milho cozido, inhame, fava, tem que ser uma comida leve. Se não nos cuidarmos, ficamos com a doença na gente.

Arqueólogo1: $E$ vocês se cuidaram?

Diretor da escola: Não, por isso que eu fiquei com medo, porque sabia que não ia me cuidar depois. Pode ser que isso não exista mais, ou exista, mas é a cultura do Kaiabi e é por isso que eu fiquei com medo e o resto dos Kaiabi também. Até eu percebi que eu amanheci todo dolorido, o trabalho que fizemos não é pesado, mas 
eu fiquei um pouco dolorido e fiquei preocupado.

Observarmos, assim, o aspecto relacional que o artefato descreve e que faz parte da rede de agenciamento, da apreensão de sentido que os vestígios arqueológicos tomam face ao coletivo indígena, e vice-versa, além dos processos epistemológicos indígenas. É importante que compreendamos esses processos para pensar criticamente a constituição de um patrimônio, já que para muitos povos indígenas, a categoria de patrimônio cultural é estranha. E são nesses momentos de estranheza que se coloca em xeque a interação do pesquisador com a própria comunidade.

È nesse sentido que a articulação com Marily Strathern (2006) pode ser realizada desde uma perspectiva arqueológica de reflexão, principalmente quando estabelecemos uma relação de multivocalidade nas pesquisas arqueológicas.

"É obviamente uma visão de curto alcance dizer depreciativamente que 'as nossas' idéias são etnocêntricas e que deveríamos ter em vista as idéias 'deles'. Ao invés disso, como argumentei, precisamos ter consciência da forma assumida por nossos próprios pensamentos, pois precisamos ser conscientes de nossos próprios interesses na questão" (nesse caso, os interesses dos antropólogos ocidentais na análise de outras sociedades). (Strathern, 2006:45)

Essa multivocalidade pode ser entendida como um espaço criado para múltiplas vozes na interpretação sobre o passado que, claro, acaba por implicar uma tensão sobre o discurso reconhecido e legitimado pelo pesquisador. Segundo autores como Kojan \& Angelo, as implicações da multivocalidade vão além de um debate teórico:

"multivocality should not be seen as a theoretical perpective to be adopted or discarted according to one's theoretical proclitivities, but is closer to truism historiography.(...) multivocality in archaeologhy cannot be simply understood as a diversity of voices, but rather needs to be undertaken as part of a larger project of interrogating and discussing the contemporary uses of the past and, primarily, acknowledging accountability with a past that is inextricably tied to a present." (Kojan \& Ângelo, 2005:397)

È importante, também, lembrar da percepção de "cultura" e cultura trazida por Manuela Carneiro da Cunha (2004). Sendo "cultura" uma referência à metalinguagem, a um certo modo de falar de si mesma. E cultura (sem aspas) em referência a contextos organizados segundo uma lógica interna de um todo social.

Assim, esse aspecto relacional da pesquisa deve levar em consideração aqueles que não costumam ser ouvidos no mainstrean acadêmico. Não apenas para outras interpretações sobre o passado, mas também, sobre a influência que outras vozes exercem sobre uma pesquisa realizada no presente. Em alguns casos - como creio ser o caso Kaiabi - a cultura material criada pelo arqueólogo, no sentido das percepções que são esboçadas no contexto social frente aos objetos escavados, se 
alinha à política de contestação indígena, em especial à luta pela terra e a sua própria percepção e mobilização da "cultura".

As considerações acima, portanto, devem ser levadas a cabo em uma pesquisa etnoarqueológica, justamente por lidarmos, ao mesmo tempo, com aspectos da cultura material e imaterial. Patrimônio material e imaterial vistos por uma ótica mais profunda daquela definida no Art.216 ${ }^{11}$ da constituição brasileira, que apesar de prever os dois aspectos patrimoniais, reifica-os em categorias sem aspectos relacionais ${ }^{12}$ . É justamente essa característica relacional que é um dos aspectos mais marcantes em uma pesquisa etnoarqueológica, são os processos sociais envolvidos em uma escavação tanto da perspectiva indígena quanto científica que se articulam em torno de uma "cultura" material e imaterial. (vide capitulo 4).

\footnotetext{
${ }^{11}$ Art. 216 - Constituem patrimônio cultural brasileiro os bens de natureza material e imaterial, tomados individualmente ou em conjunto, portadores de referência à identidade, à ação, à memória dos diferentes grupos formadores da sociedade brasileira, nos quais se incluem:

I - as formas de expressão;

II - os modos de criar, fazer e viver;

III - as criações científicas, artísticas e tecnológicas;

IV - as obras, objetos, documentos, edificações e demais espaços destinados às manifestações artístico-culturais;

V - os conjuntos urbanos e sítios de valor histórico, paisagístico, artístico, arqueológico, paleontológico, ecológico e científico.

12 “A patrimonialização interfere diretamente nessas redes sociais [(indígenas] (...) a especialização cultural é, de certa forma, o "gancho" para relações intergrupos, na medida em que ela abre a possibilidade para várias outras trocas. Os Achuar do Equador valorizam as zarabatanas dos seus vizinhos não porque não saibam fazê-las, mas porque através delas flui um intercâmbio bem mais amplo." (CARNEIRO DA CUNHA, 2005:25)
} 


\section{(In)visibilidade das perspectivas territoriais e patrimoniais: percepção indígena e discursividades políticas e científicas}

\section{TERRITÓRIO}

Pensar o território em diálogo com o patrimônio relacionado com grupos indígenas sempre será um exercício polêmico. Polêmico porque tanto a definição de território como a de patrimônio e suas gramáticas comportam categorias ocidentais que organizam determinadas práticas e representações; tanto por parte dos sujeitos e grupos que definem essas ditas categorias e as demarcam como por parte dos sujeitos ou coletivos sociais que as padecem ou devem conviver com elas. Vamos por partes.

O território sempre foi uma questão polêmica associada à noção de espaço e paisagem. As diferenças existentes entre território e paisagem apontadas por Zedeño (1997) refletem essas polêmicas:

Superficially, the proposed definition of territory approximates that of "cultural" or "social" landscape in that this type of landscape, too, may be defined as an aggregate of land, natural resources, and objects of human manufacture. In practice, however, a territory differs from a landscape at two fundamental points. First, landscapes are, by definition, contiguous spaces that can be comprehended at a glance (ALLEN; HOEKSTRA, 1992, p. 47; JACKSON, 1984, p. 8), whereas a society's territory may encompass two or more noncontiguous spaces or even discrete sites or places [for a detailed discussion of place-bound territorial units see Ingold (1986)]. And second, landscapes are units whose boundaries are perceived by the viewer (ALLEN; HOEKSTRA, 1992, pp.47, 69; COPPS, 1995, p. 55), whereas territory boundaries are established by (a) the society that uses and controls a

given space and (b) other social groups that use and control adjacent spaces (Soja, 1971, p. 34, Morehouse, 1996).. (ZEDEÑO, 1997, p. 63)

Para autores como Ashmore \& Knapp (1999) o que mudou na arqueologia, apesar de esta sempre ter tido interesse em estudar o espaço e a paisagem, foi a reflexão sobre a natureza da paisagem, a percepção da natureza e o seu papel no inquérito arqueológico, além da inclusão do aspecto simbólico na construção 
de uma percepção da paisagem, que pode ser interpretada localmente de forma subjetiva (INGOLD, 2000; TILLEY, 1994).

Qual seria, portanto, a definição de território que ressaltasse a qualidade reflexiva?

Porem, não ser o foco desse trabalho, recorramos a alguns autores que estudaram essa noção com um viés problematizador. As aproximações de Milton Santos (1994) nesse sentido são não só acertadas como também provocativas.

Assim, segundo o ator o território é "o quadro da vida de todos nós, na sua dimensão global, na sua dimensão nacional, nas suas dimensões intermediarias e na sua dimensão local, que constitui o traço de união entre o passado e o futuro imediatos" (SANTOS, 1994, p. 19). O território se constitui, portanto,

"(...)a partir dos seus usos, do seu movimento conjunto e do de suas partes, reconhecendo tanto suas particularidades como suas complementaridades. Tratase da divisão territorial do trabalho e da vida social que permite pensar o território como ator, isto é, o território no seu papel ativo. (SANTOS; SILVEIRA, 2001, p. 11)

Em sua construção teórica, tanto o território como a região são expressões da espacialização do poder e das relações de cooperação e do conflito que dela derivam. Assim, através de Santos, podemos ver como, em nosso caso etnográfico, a noção de território torna-se importante para observar processos em que esse espaço foi subtraído:

Ancião3: [...] Aí ele [o fazendeiro] tinha muito gado, vinha aqui mandar guardar, pegar o gado, já que era muito difícil de levar para lá [vender em algum entreposto]. Para o senhor ver como é a história de antigamente, como é que nós fomos roubados em Lalima. Hoje os fazendeiros ocupam nossa terra por causa disso, o que é que acontecia? O branco fala para nós assim "Ah, mas o índio tem que ter documento, tem que tem que ter marco".

Arqueólogo3: Marco?

Ancião3: Para falar que a terra é dele. "Não, senhor", eu falei para o fazendeiro vizinho quando ele veio questionar a terra, "Não senhor". Índio não sabia escrever nem ler naquele tempo, naquele tempo não existia, o índio nunca soube ler e nunca soube escrever. Mas onde ele [o índio] passava, ele lavava [descascar, marcar] um pau para falar que é nosso e punha uma pedra branca. [...] Assim que meu finado avô falava e ficávamos conhecendo [a historia dos limites territoriais] pelas histórias dele. 
É necessário, então, a partir desse testemunho, ampliar a noção de território e introduzir o conceito de espaço, também desde a perspectiva de Santos (1994), que comporta uma proposta teórica, mas também metodológica, a qual concebe o espaço como um conjunto indissociável de sistemas de objetos e de ações. Os sistemas de objetos não acontecem sem os sistemas de ações, e esses últimos não acontecem sem os primeiros. É interessante observar a perspectiva dialógica relacional entre objetos e ações, um dos pontos nodais em nossa proposta de focalizar - entre outras coisas - as interações entre ação e objetos num sentido amplo. O autor referido acrescenta que o espaço está construído historicamente e que esse espaço geográfico, na atualidade, é um sistema de objetos cada vez mais artificiais, provocado por sistemas de ações igualmente artificiais - artificial no sentido de que existe uma agência humana sobre eles.

Essas noções interferem radicalmente na noção de território de uma comunidade indígena e podem aclarar momentos de conflitos entre arqueólogos e essas populações, como fica evidente nos laudos arqueológicos de uma barragem nos arredores do Parque Indígena do Xingu, que suscitou debates sobre a instrumentalização da ciência em relatórios de impacto ambiental, justamente no ponto referente à percepção da paisagem e território sagrado do Quarup. ${ }^{13}$ Tal polêmica possibilitou uma discussão mais profunda sobre a relação entre arqueólogos, patrimônio e comunidades indígenas, como foi esboçada no I Seminário Internacional de Gestão do Patrimônio Arqueológico Pan-Amazônico, ${ }^{14}$ mais especificamente na seção "preservação do patrimônio arqueológico em terras indígenas" - a moção de encaminhamento decorrente deste seminário pode ser verificada no Anexo 5 - com destaque para o ponto sobre "terra indígena":

No presente trabalho considera-se como terra indígena tanto aquelas terras administrativamente demarcadas pelo governo brasileiro (Tls), aquelas de alguma forma reconhecidas e assumidas pelos outros países da América do Sul, como as áreas consideradas tradicionais pelas populações indígenas, demarcadas ou não, em especial seus locais de significância simbólica/ sagrada/ cultural. Portanto, as diretrizes técnicas, éticas e operacionais relacionadas ao longo da presente Moção devem ser igualmente aplicadas em todas as situações acima mencionadas, que

\footnotetext{
${ }^{13}$ Disponível em: <www.socioambiental.org/nsa/nsa/detalhe?id=2317>

- (Acessado em: 27/10/2009)

14 Manaus, 5 a 9 de novembro de 2007.
} 
passam a ser designadas simplesmente como "terras indígenas tradicionais".

É nesse sentido também que Geiger (1996) pensa o território associado ao espaço como uma extensão delimitada que inclui, definitivamente, uma relação de poder por parte de um indivíduo ou um grupo social. Esse território tem limites de soberania e propriedade, inclui relações de apropriação - disciplina e vigilância e, como é lógico pensar, impõe uma determinada jurisdição que transmite a idéia de cercamento espacial e cerceamento político, assim como econômico e simbólico. Vejamos então o seguinte relato:

Ancião1: Eles [os índios] se reuniram aqui e não correram mais. Eram bem armados, eram guerreiros, tinham até armas de guerra, mosquetão, carabina 44.

Arqueólogo3: Enterrava [as pessoas] com mosquetão?

Ancião1: Não. Chegou um chefe [de posto da Funai] e desarmou nós tudo. Aí os fazendeiros queimaram nossas casas aqui, aí cada um arrumou um porrete, uma flecha, para correr atrás daqueles que vinham aqui, dos fazendeiros. Decerto pagaram o chefe e ele tirou todas as armas.

Arqueólogo3: Como chamava esse chefe de posto?

Ancião2: André Leite.

Assim, parecer haver duas jurisdições, a perspectiva ocidental e a indígena, postas em jogo nas relações de poder acima mencionadas. As noções de espaço e de território, portanto, derivam da idéia de territorialidade como "o grau de controle de uma determinada porção de espaço geográfico por uma pessoa, um grupo social, um grupo étnico, uma companhia multinacional, um Estado ou um bloco de estados" (MONTAÑEZ, 1997, p. 198). A partir de esses dados, o que podemos observar de nossas interações em campo é que tanto os Kaiabi como os Terena apresentam múltiplos relatos de desterritorialização no sentido proposto por Geiger (1996): como um processo de perda do território derivado da dinâmica territorial e dos conflitos de poder entre diferentes agentes territoriais.

Arqueólogo3: Qual é o nome dos marcos que tem aqui? Ancião2: Não sei o que significa... Tem de ir lá ver...

Arqueólogo3: Além daquele marco tem outro?

Ancião2: Diz que tem, mas eu não sei, não cheguei a ver... Na cerca mesmo que vai pra cá tem um cunhado que é expedicionário que ajudou a desmanchar a cerca... que o dia que entrasse em questão a cerca [o limite 
territorial], podia chamar ele que ele que ajudou a desmanchar da divisa pra cá... Divisa com o rio...

Arqueólogo3: Que mais tem de marco?

Ancião2: De marco que conheci era só isso aí... Pedra Branca, Lazão.... da placa da estrada [da entrada da aldeia] pro rio.

Arqueólogo3: E a pedra branca, onde é?

Ancião2: É pra cá, perto do Lazão... onde tem um pé de jacobeiro. Essa aí que tá difícil...

Arqueólogo3: Difícil de quê?

Ancião2: Difícil de requerer...

Arqueólogo3: Ah! Área lá [tomada pelo fazendeiro vizinho]...

Ancião2: É. Quem me mostrou isso foi o tio João, faz vinte e pouco anos que ele morreu. Nós caçávamos, aí ele me mostrou. Aí guardei na idéia, e quando o meu filho me informou o que vocês estavam caçando (pesquisando), contei para ele.

Ancião1: Para vocês terem uma idéia de quanto arruinaram a cerca...

Ancião2: Dr. Bonifácio Carvalho... que comprou essa parte aí que falam que é nossa.

Ancião1: Comprou, não. Mediu aí, certo!? Foi o "Dr. Bonifácio que mandou." Que era dono da fazenda Engenho, buscou outro que mediu.

Mas também, especialmente no caso Kaiabi, expressa-se outro conflito, que abrange não somente os brancos que avançaram apropriando-se de espaços alheios, mas também outros que enfrentam diferentes grupos étnicos, em tensão constante pelo domínio da construção de um espaço que lhes pertença:

Arqueólogo4: E isso aqui será que era de Kaiabi ou era antes de Kaiabi isso aí, do pessoal que morava aqui?

Ancião Kaiabi/Munduruku: Essa história eu tô falando do tempo que nós guerreava com outro índio, do tempo que nós espalhamos, entramos no mato, os bravos entravam no mato, do tempo que a gente guerreava com outro índio. Esses que moravam aqui, dizem que eles faziam da casca de pau a canoa. Eles [os kaiabis] vão pro outro lado por causa do outro índio que eles estavam brigando, por isso que tem muita tapera velha [antigas aldeias] por aí. É do tempo que nós brigava com outro índio, assim que meu pai conta a história. [...] Nós atacávamos e eles, então, mudavam para outro lugar, aí eles deixavam a aldeia deles abandonada. Ali no tabuleiro [um sítio geográfico] teve muitos donos. 
Observamos, então, que toda essa relação social acontece num território-espaço determinado cristalizado em territorializações específicas, que são uma espécie de arena política, simbólica e econômica de múltiplas interações determinadas sócio-historicamente. Nesse sentido o território não é somente um espaço de poder, mas também um espaço de agência para a resistência dos grupos oprimidos por um determinado processo de territorialização colocado em ação por um Estado. Sendo assim, a idéia de território desde uma perspectiva ocidental é incorporada à agenda indígena:

Esta incorporação do discurso do Estado fundamenta a etnicidade genérica e jurídica que os povos indígenas reivindicam, ao se referirem à sua condição de expropriados. A inscrição de seu projeto de continuidade social diferenciada dentro do debate político nacional só é culturalmente possível a partir de tal registro, registro esse que permite a mobilização de alianças e movimentos de opinião favoráveis no seio da sociedade dominante a fim de contrabalançar a pressão dos interesses econômicos sobre suas terras.. (ALBER 1995:03)

Posta essa dinâmica discursiva, podemos observar esse processo no caso kaiabi, através da fala da liderança kaiabi, não só referente a território e demarcação (que, aliás, causam atualmente um intenso processo de disputa), mas no compromisso esperado do pesquisador que atua em área indígena:

Liderança kaiabi: [...] e vimos que a pesquisa [arqueológica] iria ser feita para nós mesmos: para mostrar para não-índio que ali existia índio.

Com isso conversamos com a comunidade e em seguinte com a Funai de Brasília e também da regional. Para nós que estamos no dia-a-dia o Arqueólogo4 iria ser um parceiro de luta.

[...]. [E pensamos que] quanto mais pessoas, antropólogos ou outros pesquisadores fizerem esse tipo de trabalho, talvez, que isso seria bom para nós, para mostrar para outras autoridades, enfim, os outros que acham que nunca existiu índio na região. Então isso nós fomos explicando para a comunidade, o Arqueólogo4 também foi explicando, com isso a comunidade entrou no acordo para que se fizesse pesquisa dentro da área.

Ou ainda pela perspectiva do pesquisador:

No caso dos Kaiabi esta percepção do nosso trabalho como um recurso importante na arena das suas disputas territoriais existiu desde o momento de negociação da pesquisa e foi quase a condição para a sua realização. A investigação das antigas aldeias de ocupação Kayabi foi prioridade inicial de nosso trabalho e, especialmente, daquelas aldeias que 
constavam do laudo antropológico realizado com o objetivo de delimitar a TI Kaiabi (vide RODRIGUES, 1993). O interesse dos Kaiabi pela pesquisa, portanto, foi extremamente político e eles se empenharam no seu desenvolvimento, como interlocutores e auxiliares de pesquisa, com um objetivo que estava além do ganho econômico. Com o tempo, esta percepção da pesquisa foi se ampliando e os Kaiabi passaram a compreendê-la como uma forma de resgate de sua história de ocupação territorial, e neste caso, tradição oral e memória foram sendo acionadas para dar outros significados aos registros arqueológicos (SILVA et al., 2009)

É interessante, portanto, contrastar as diferenças entre as experiências Kaiabi e Lalima e verificar como o acionamento do discurso sobre território influiu sobre a pesquisa arqueológica em área indígena de forma diferente. No caso de Lalima, foi no dia-a-dia do trabalho de campo que as demandas territoriais indígenas se acentuaram, forçando-nos a nos posicionarmos politicamente frente a elas.

\begin{abstract}
$\mathrm{Na}$ aldeia Lalima, nós dispensamos grande parte do nosso tempo em campo investigando os sítios históricos de ocupação Terena [p.ex. sítios Tapera do Urumbeva, Tapera do Limpão e Tapera do Gino] e Guaikuru [p.ex. sítio Tapera do Pirizal]. Num determinado momento, inclusive, nós fomos chamados a localizar os marcos antigos (moirões de madeira) de delimitação da TI de Lalima e que hoje estão nas terras das fazendas circunvizinhas. A partir disso, conseguimos perceber que, se num primeiro momento, havia desconfiança e incompreensão com relação a nossa pesquisa em Lalima, num segundo momento, nosso trabalho passou a fazer sentido, especialmente para as lideranças indígenas. Estas compreenderam a potencialidade do conhecimento que estávamos produzindo na sua luta pela reivindicação do seu território, usurpado pelos fazendeiros ao longo dos anos. Além disso, passamos a ser vistos como agentes facilitadores de uma relação mais simétrica com os órgãos públicos. Antes de deixarmos a aldeia, redigimos uma carta ao Presidente da Funai - a pedido das lideranças de Lalima solicitando que este atendesse às reivindicações indígenas para a constituição de um novo Grupo de Trabalho para estudar a ampliação de seu território. (SILVA et al., 2009)
\end{abstract}

Portanto, o processo de colaboração da pesquisa passou a se configurar como um ato balanceado - ora atendo aos interesses dos arqueólogos, ora atendendo aos interesses indígenas (NICHOLAS et al., 2008), porém, aos poucos gerando ansiedade e questionando as práticas arqueológicas em campo. Tal questionamento não impedia o trabalho de campo, mas, isso sim, gerava o necessário ato reflexivo sobre arqueologia e seus pressupostos teóricos.

Arqueólogo1: Acho que ele [um colega acadêmico] tem que entender que mudamos o foco, de histórico-culturalista para histórico-cultural, focado no processo.

Arqueólogo2: Não, o que estamos fazendo é histórico-culturalista menos essencialista. Mais correto, mais verdadeiro, menos essencialista. Mais crítico, 
mais relativista, mais processual mesmo, no sentido de pensar o processo histórico.

\section{Patrimônio}

Todo esse jogo de apropriações espaciais relaciona-se diretamente com a idéia de patrimônio, ao impor uma abordagem que abrange não só a historicização do espaço próprio e alheio, mas também a materialidade dos objetos, como uma forma de entender os diversos processos através dos quais a noção de patrimônio é construída desde uma perspectiva indígena, para, em seguida, retornar à arena política com uma reivindicação própria.

\footnotetext{
Arqueólogo3: E machado de pedra?

Ancião1: Às vezes se encontra por aí, no nosso tempo a gente usava pra cortar árvore machado de metal. Nós achávamos só machado quebrado.

Arqueólogo3: Em qual parte tinha mais?

Ancião1: Qualquer parte, sempre que nós fazia uma lagoa, achava.

Arqueólogo3: De quem que era?

Ancião1: Ninguém sabe.

Ancião2: Decerto era de quem morava aqui de primeiro, com aquelas revoltas dos índios, correram, largaram ou mataram. Vieram os Kadiwéu e acamparam aqui.

Ancião1: Agora, aqui é patrimônio dos índios [a aldeia e o machado]. É dos netos, dos bisnetos.
}

Como tentamos expressar desde o começo deste capítulo, achamos difícil identificar uma abordagem de patrimônio cultural em termos étnicos, já que muitas sociedades ameríndias se constituíram a partir de redes de relações históricas e de processos seculares de troca numa área determinada ou não. Com freqüência alguns componentes culturais são compartilhados por todo um grupo regional, e esses componentes costumam ser reelaborados em contextos particulares, permitindo que cada grupo reconheça e valorize o que considera parte de seu próprio patrimônio cultural. No entanto, o termo "patrimônio", mesmo que seja usado por coletivos indígenas, costuma ter referenciais qualitativos diferente dos nossos (ocidente), não apenas numa percepção de senso comum, como também acadêmica. Num interessante aporte, Funari (2007) descreve as definições lingüísticas da origem do termo e sua ligação com o processo capitalista, notadamente vinculado à percepção de propriedade e consciência histórica marxista. Manuela Carneiro da Cunha, mais especificamente, aponta a construção do sentido de "patrimônio": "dando como natural um termo associado 
a uma ontologia de propriedade que foi penosamente construída a partir do século XVII" (CARNEIRO DA CUNHA, 2005, p. 18).Isso implica a percepção analítica de regimes culturais em diferentes contextos culturais, ou seja, o conjunto heterogêneo de instituições, vocabulários, normas e processos de transmissão, associados a um conjunto de práticas (pedagógicas, projetos de mercado e financiamento) objetos da "cultura". Portanto,

\begin{abstract}
A patrimonialização interfere diretamente nessas redes sociais [...]. [Por exemplo] a especialização cultural é, de certa forma, o "gancho" para relações intergrupos, na medida em que ela abre a possibilidade para várias outras trocas. Os Achuar do Equador valorizam as zarabatanas dos seus vizinhos não porque não saibam fazê-las, mas porque através delas flui um intercâmbio bem mais amplo. (CARNEIRO DA CUNHA, op. cit., $2005: 25$ )
\end{abstract}

Assim, a percepção indígena faz referência à dinâmica de cultura material e imaterial, e também nos revela um pouco mais sobre esse processo conceitual que vai além das apreensões tecnológicas próprias de um estudo sobre cultura material. Portanto, o foco não é mais colocado no produto, mas na produção, nos processos, apesar de voltar ao produto quando um conhecimento passa a ser materializado.

João Asiwefo Tiriyó nos oferece o seguinte esclarecimento:

Todos nós sabemos que o imaterial é a fonte do patrimônio material. Para nós, é tudo entu, fonte. Está na cabeça desse rapaz que desenhamos, está no pensamento dele. Se ele não tiver esse conhecimento dentro dele, como é que ele vai fazer os enfeites que ele está usando aqui? Como é que ele vai poder repassar para os filhos dele? O patrimônio imaterial é o conhecimento que foi repassado para esse rapaz. É o invisível que está dentro, que comanda tudo. (GALLOIS, D. Patrimônio Cultural Imaterial e Povos Indígenas. IEPE, 2006, p. 8).

De qualquer forma, fica a indagação de Alan Babadzan (2001) de como pesquisar as relações sociais envolvidas no processo de patrimonialização, que envolve a revisão de ideais característicos da modernidade, como a noção de autenticidade e imperativos ideológicos referentes à construção de um Estado nacional e seu 
território, processo que adquire cada vez mais valor estratégico na percepção da diversidade cultural trazida à tona pela arqueologia (FUNARI, 2008).

Talvez esses processos fiquem mais claros se analisarmos a rede discursiva desenhada em torno de um caso concreto. Enquanto realizávamos etnografia para a pesquisa do mestrado, verificamos a preocupação constante tanto dos índios kaiabis quanto de nossos colegas arqueólogos sobre as obras de infraestrutura planejadas pelo governo federal. E de fato, recentemente, foi tirado da gaveta pelo governo brasileiro o antigo projeto desenvolvimentista da hidrovia Tapajós-Teles Pires, o chamado "PAC ${ }^{15}$ das hidrovias", que prevê a implementação e/ou expansão de três hidrovias (Tietê, Tocantins e Tapajós-Teles Pires). Tal projeto, elaborado pelo Departamento Nacional de Infra-estrutura e Transporte (DNIT), visa o escoamento e desenvolvimento da produção dos estados do centro-oeste e sudeste.

O que nos chama atenção é o emblemático silêncio em torno dos impactos socioambientais de tais projetos. Em especial a hidrovia Tapajós-Teles Pires tem previsto o impacto em unidades de conservação ambiental e áreas indígenas demarcadas e em processo de demarcação entre o norte de Mato Grosso e sul do Pará.

\section{Unidades de Conservação Ambiental e Terras Indígenas na Área de Estudo}

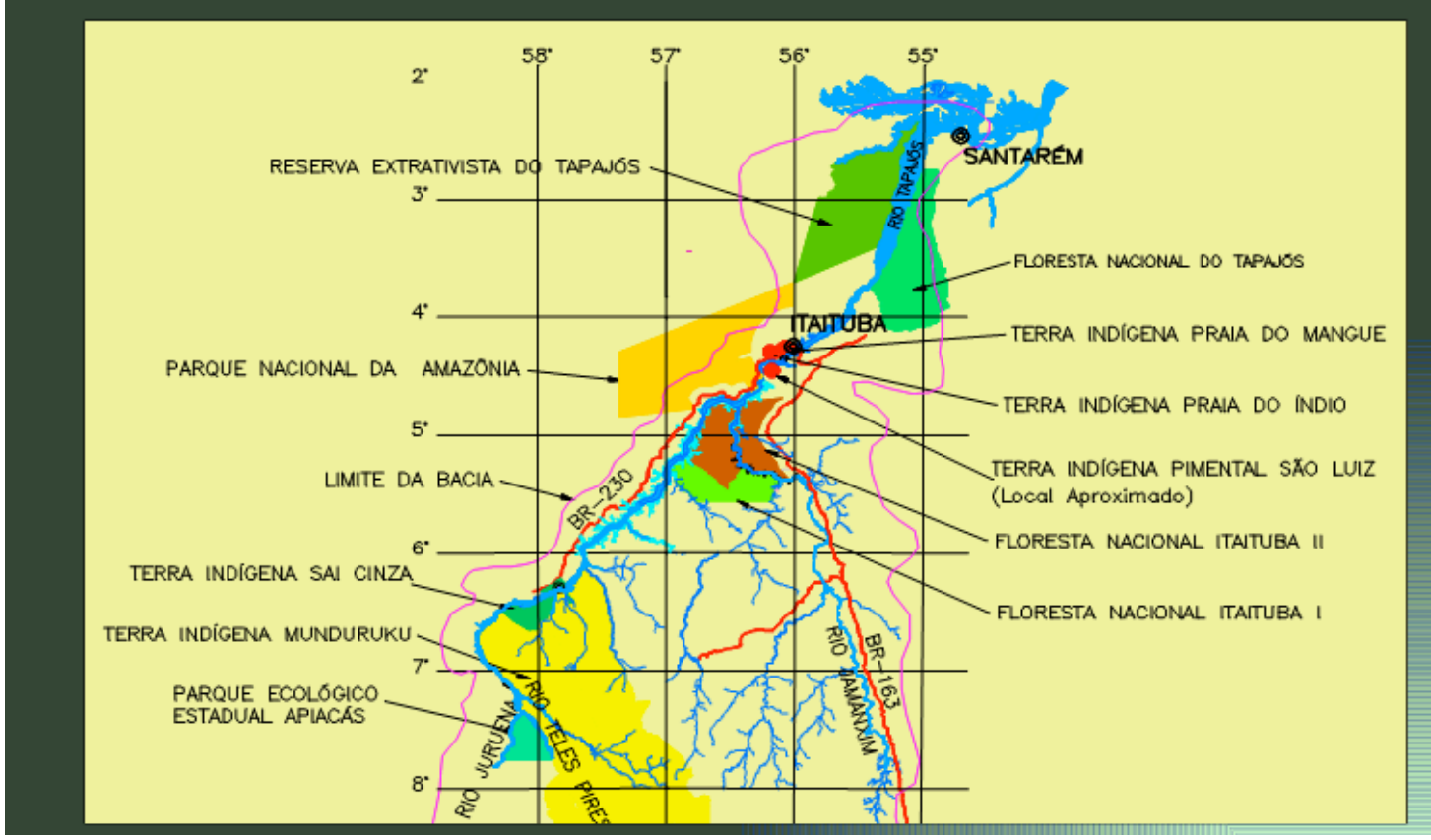

\footnotetext{
15 Plano de Aceleração do Crescimento. Disponível em: <http://www.estadao.com.br/noticias/economia, dnit-prepara-pac-dehidrovias-de-ate-r-18-bi,326149,0.htm>. Acesso em: 30/03/2009.
} 
Fonte: Administração das Hidrovias da Amazônia Oriental, Michel Dib Tachy. (http://www.ahimor.gov.br/tapajos/index.htm Acessado em: 12/12/2009)

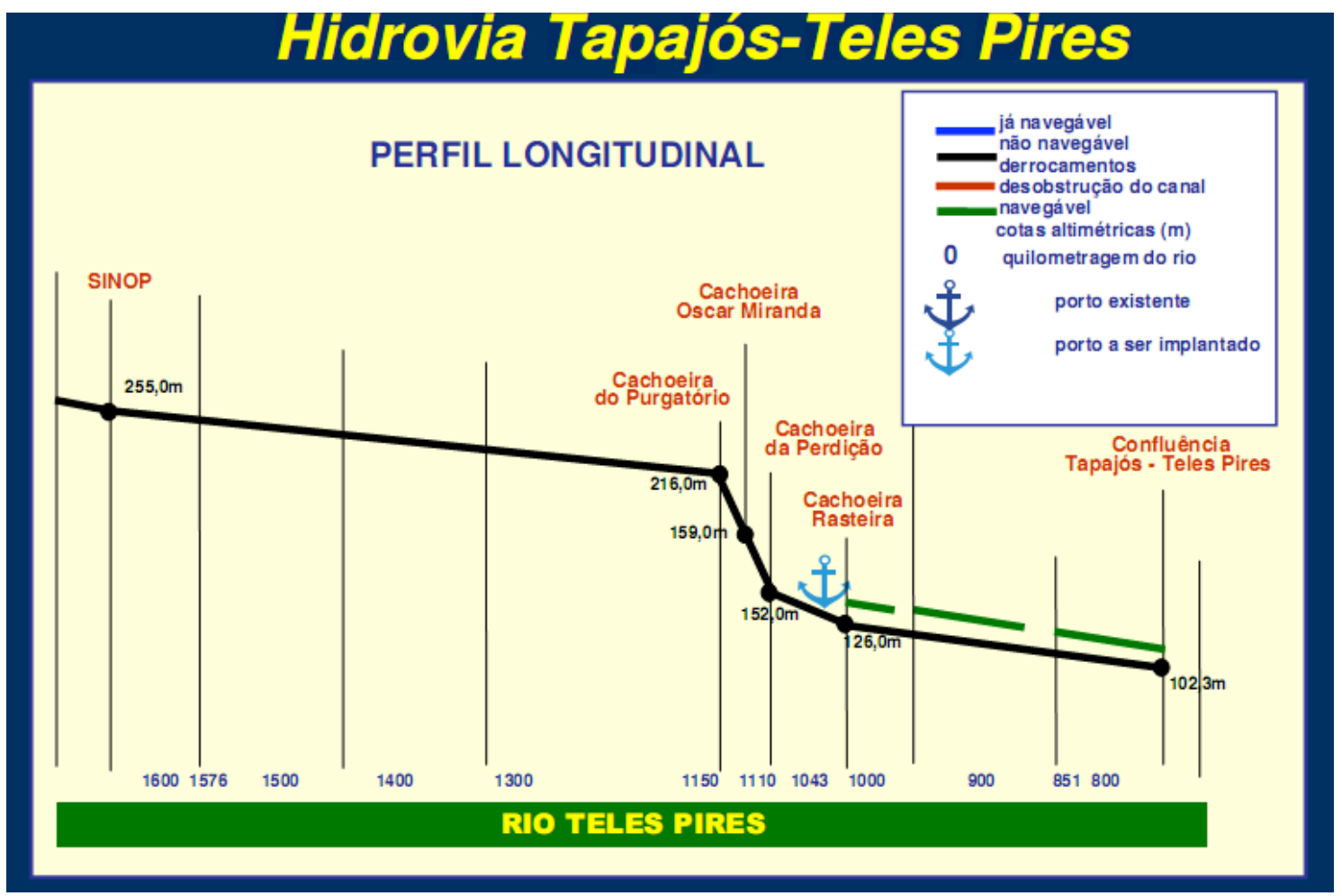

Fonte: Administração das Hidrovias da Amazônia Oriental, Ana Paula Fajardo. (http://www.ahimor.gov.br/tapajos/index.htm Acessado em: 12/12/2009)

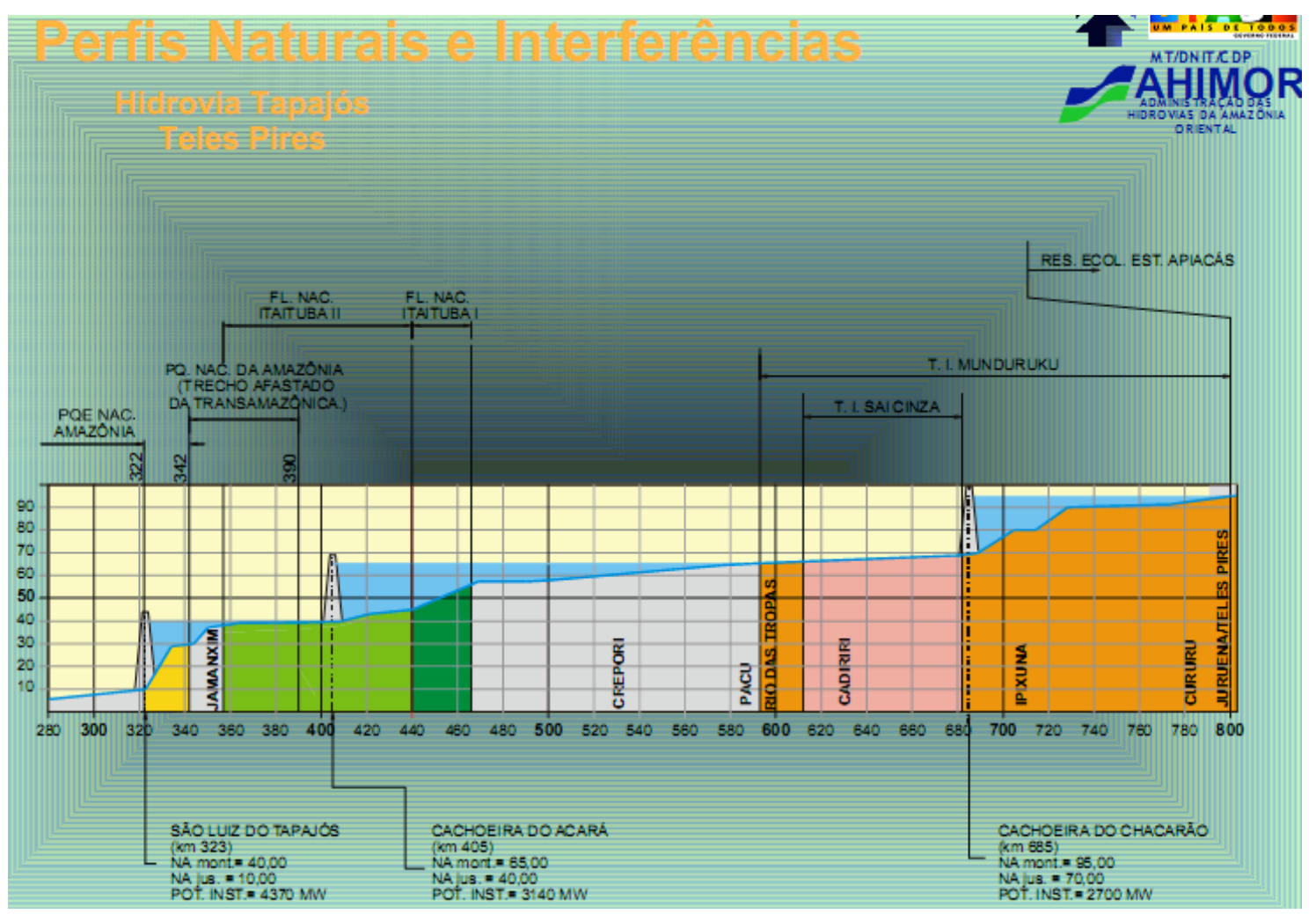


Fonte: Administração das Hidrovias da Amazônia Oriental, Michel Dib Tachy. (http://www.ahimor.gov.br/tapajos/index.htm Acessado em: 12/12/2009)

Com a análise atenta dos gráficos acima percebemos que o impacto da hidrovia vai além da área indígena Munduruku, englobando também a TI Kaiabi.

Posto esse contexto contemporâneo da área pesquisada por nossa equipe de arqueologia, cabe a reflexão sobre os aspectos patrimoniais envolvidos não só com a pesquisa acadêmica em si, mas também, com o empreendimento do porte da hidrovia Tapajós-Teles Pires. Quais agências são mobilizadas (ou tornadas invisíveis) em torno do patrimônio cultural indígena?

Segundo Enrique Florescano (1993) a problemática de patrimônio cultural está relacionada com três variáveis: 1) a maneira como se resgatam e selecionam certos bens e testemunhos do passado; 2) geralmente essa seleção é realizada pelos grupos sociais dominantes; 3 ) no caso dos Estados Nacionais, a construção de patrimônio cultural está articulada com aquilo que é próprio da nação e aquilo que se reconhece como patrimônio universal.

Ao pensar, ou melhor, conceber o patrimônio como uma prática social constitutiva, Arantes (1989) coloca o fenômeno na dinâmica social da produção e reprodução de significados. Nesse sentido, propõe deslocar o foco de análise desde os procedimentos técnicos centrados em "critérios de identificação e procedimentos de conservação de objetos tomados em sua materialidade como signos armazenados num dicionário" (Arantes, 1989), e prestar atenção aos processos de construção de sentido a partir da apropriação do patrimônio por parte dos diversos atores sociais.

Devemos concordar então que os segmentos sociais vão pensar a idéia de patrimônio desde a sua própria imagem e representação do mundo num sentido político, econômico e simbólico. Não é difícil, seguindo esta linha, encontrar dados que apóiem nossa proposta. Porém, a patrimonialização constitui um processo pelo qual se constrói todo um sistema de bens considerados de interesse para toda a nação. E há aqui um paradoxo - quase um dilema - em termos de classe. A idéia de patrimônio nem sempre pode fugir da armadilha etnocêntrica das classes dominantes. Vejamos alguns exemplos. No caso do projeto hidroviário 
Tapajós-Teles Pires, o impacto sobre um importantíssimo patrimônio cultural é ignorado. O discurso midiático em torno do projeto visa colocar as questões ambientais e sociais em contraste com a imagem desenvolvimentista incorporada na figura do colonizador pioneiro Ariosto da Riva (fundador dos municípios de Alta Floresta, Apiácas e Paranaíta, no norte de MT). No jornal Circuito Mato Grosso, na matéria "Em busca de uma logística melhor", de Eduardo Gomes, podemos observar algumas discursividades em torno desse processo, tais como: "A hidrovia é sonho coletivo de Alta Floresta e do Nortão", "mordaças ambientais praticamente impediam o avanço do projeto", "o projeto sofre pressões ambientais internas e internacionais" ${ }^{16}$. Observa-se ainda o descaso não só com os impactos ambientais como também em relação às populações tradicionais que vivem na região.

\begin{abstract}
Mesmo com o sinal verde do Congresso a hidrovia Tapajós-Teles Pires ainda terá que superar o embargo judicial imposto pela Vara Descentralizada da Justiça Federal de Santarém, que desde 1999 proíbe obra nos dois rios, acima de Itaituba, sob o fundamento do Ministério Público Federal de que a margem esquerda do Tapajós nas imediações de Itaituba seria área de perambulação dos índios da etnia Munduruku. "É preciso abrir esse cadeado", critica Homero [deputado federal]. ${ }^{17}$
\end{abstract}

Essa "arena política" em torno das políticas de preservação e patrimônio envolve não só os órgãos institucionais, como também os discursos locais das classes dominantes, que consideram como seu patrimônio identitário o legado do colonizador territorial encarnado na imagem do "último bandeirante" Ariosto da Riva, fundador do município de Alta Floresta. Este fato pode ser verificado no site o da prefeitura municipal de Alta Floresta (www.altafloresta.mt.gov.br) e no livro $A$ lenda do ouro verde: política de colonização no Brasil contemporâneo, de Regina Beatriz Guimarães Neto.

Assim, seguindo o contexto arqueológico do processo de patrimonilização, Cristina Bruno (2005) aponta três elementos-chaves para apreensão dessa problemática. O primeiro se refere ao papel coadjuvante da arqueologia nas interpretações da história do Brasil. Em seguida, a trajetória institucional das

\footnotetext{
16 Disponível em: <http://www.circuitomt.com.br/impresso/materia/1240>. Acesso em: 30/03/2009.

17 Disponível em: <http://www.circuitomt.com.br/impresso/materia/1240>. Acesso em: 30/03/2009.
} 
pesquisas arqueológicas, e. por fim, as razões que preponderam nas iniciativas museológicas/patrimoniais de empreendimentos. Sua posição conflui com a perspectiva posta por Arantes (1989):

Sem duvida, esta atividade [preservacionista] acabou se estancando, se tecnificando, perdendo assim, durante muito tempo, seu sentido político mais amplo, para acabar transformada e entendida como sendo válida em si e por si mesma. (1989:13)

Portanto, como vimos nos Capítulos 2 e 3, é na memória social indígena que encontramos o melhor caminho para a qualificação da noção de patrimônio. $O$ objeto cultural (seja ele de origem arqueológica ou não) desencadeia a memória social como elemento cognitivo com o passado. Essa percepção etnográfica da constituição de um patrimônio indígena torna mais complexa a noção de patrimônio imposta pela política oficial. As disputas regionais, dessa forma, são postas em evidência, e em torno delas são mobilizadas algumas agências, como a herança colonizadora, os meios de comunicação, a universidade e os órgãos governamentais.

Assim, a hidrovia Tapajós-Teles Pires é mais do que um projeto de infra-estrutura nacional. Ela é o ponto focal ao redor do qual se desenrolarão conflitos territoriais, e é justamente na percepção de patrimônio que a arqueologia se defrontará com seu aspecto público:

"Os aspectos públicos, de interação e ação conjunta com as comunidades tanto locais como regionais, nacionais e transnacionais, passaram a representar parcela crescente e cada vez mais significativa da prática e teoria arqueológica." (FUNARI, 2008, p. 5)

Ou seja, ela será posta em xeque tanto na elaboração do relatório de impacto ambiental para tal empreendimento, quanto em seu caráter teórico-político frente às comunidades tradicionais e elites regionais.

Retomemos a discussão acima sobre território, resumidamente esboçada no texto de Zedeño (1997:73):

"Land, resources, and objects of human manufacture each have their own life histories. Territories as object aggregates, in turn, follow specific trajectories that are the combined result of the natural history of the land and its resources and the social history of land and resource use. Societies establish, maintain, and 
transform territories through a variety of inter- actions and activities. These interactions and activities include not only effective use of the landscape but also relationships of land and resource ownership within a society as well as between the society and its neighbors (INGOLD, 1986). Through time, the material record of these interactions and activities reflects adjustments of land-use strategies to a changing environment as well as changes in the landscape owing to human modification."

É possível acrescentar a percepção de representações históricas e sociais que atribuímos aos objetos tanto na perspectiva do arqueólogo (HOLTORF, 2002) quanto na do indígena. Este elabora uma intricada articulação de percepção territorial e patrimônio e pode estar conectada tanto a discursos cosmológicos quanto a discursos políticos frente à cultura ocidental.

Portanto, vestígios arqueológicos relacionam-se não só com um longínquo passado, mas também como elemento fundamental para o futuro - não muito distante - de "reprodução cultural" (para usar a terminologia da Funai para demarcação territorial), já que as articulações em torno de patrimônio, território e cosmologia (Capítulos 2 e 3) fazem parte do modo de ser indígena. 


\section{Conclusão}

A reflexão acerca da construção do campo etnográfico impôs uma serie de considerações especialmente delicadas para a realização deste trabalho. Vejamos com mais detalhe.

Dois campos tiveram que ser "construídos". Como já esboçado, o primeiro foi a aldeia Lalima (Miranda-MS). A abordagem etnográfica concentrou-se no desenvolvimento da pesquisa arqueológica, no "fazer ciência" e nas conexões sociais resultantes. O segundo campo etnográfico, no ano seguinte, foi na Terra Indígena Kaiabi (Alta Floresta-MT). A abordagem etnográfica, nesse caso, esteve focada na percepção indígena do trabalho arqueológico e a agência relativa aos vestígios arqueológicos. Assim, em relação às experiências na Aldeia Lalima e na TI Kaiabi, é importante destacar alguns temas presentes no decorrer das análises. O primeiro é o processo de formação da pesquisa etnoarqueológica do projeto "Arqueologia, etnoarqueologia e história indígena - um estudo sobre a trajetória de ocupação indígena em territórios do Mato Grosso e Mato Grosso do Sul: a Terra Indígena Kaiabi e a aldeia Lalima", principalmente no que se refere a sua negociação junto à comunidade local. Em seguida temos o feedback da pesquisa, que, no geral, configurou-se no interesse da comunidade em um futuro uso político. Ou seja, em uma instrumentalização de nosso trabalho de pesquisa para a ampliação da área indígena homologada pela Funai e/ou para seu reconhecimento territorial. Uma outra temática trabalhada foi o impacto da pesquisa sobre a dinâmica local, a contextualização da política interna da aldeia e a observação de como um grupo de pesquisadores insere-se nessa dinâmica principalmente no caso de Lalima.

A agência relativa dos vestígios arqueológicos se caracterizou pelo exercício reflexivo da pratica dos atores em campo. Ou seja, a observação de como os artefatos são usados para criar representações de mundo ao invés de entender as representações em si, tanto pelo olhar indígena quanto pelo do cientista. Nesse sentido foi levado em conta o aspecto relacional dessas duas perspectivas, ou seja, o agenciamento descrito pelo artefato. 
Vejamos bem: dois campos e dois propósitos articulados. Por quê? Porque, segundo o marco teórico apresentado, fazer ciência, e sua epistemologia, envolve sujeitos em ação. Sujeitos que percebem a realidade e constroem acertos e conclusões a respeito da realidade sentida e interpretada.

$\mathrm{Na}$ primeira parte da pesquisa foi necessário considerar e interpelar a reflexão arqueológica em campo, que, de fato, também interpelou a nossa reflexão como arqueólogos. Nesse sentido, percebemos que o poder que os pesquisadores atribuem às descobertas que se fazem num sítio arqueológico se sustentam mais nas relações e convenções estabelecidas pela ciência que na materialidade mesma dos artefatos encontrados. Não queremos dizer que esta materialidade não seja vital para as descrições e interpretações, simplesmente argumentamos que as mesmas estão permeadas pela agência humana, uma agência composta de múltiplos discursos, que se põem em ação a todo tempo no desenvolvimento de uma pesquisa arqueológica. Portanto, e já estabelecendo uma conexão com a segunda parte da pesquisa de campo, é importante mencionar que tanto na aldeia Lalima como na aldeia Kaiabi, a reflexão desta dissertação se manifestou como uma imediata necessidade de recuperar os sujeitos sociais como núcleo central da pesquisa arqueológica, no sentido de serem agentes que muitas vezes remetem a diferentes concepções do mundo. Na construção do campo, no sentido da produção do "fato" científico, essas múltiplas visões de mundo se manifestaram, constantemente, nas práticas e representações de todos os atores envolvidos na performance da pesquisa.

Neste sentindo, é necessário fazermos uma reflexão sobre multivocalidade. Nem todos os pontos de vista sobre o passado ou fontes de informação são igualmente válidos. Cada perspectiva é construída sobre um ponto de partida inicial - algumas vezes, essencialista ou com uma agenda política implícita. Portanto, multivocalidade não é apenas a incorporação de interesses indígenas em pesquisas ou publicações arqueológicas, mas, também, o reconhecimento dos diferentes interesses implicados na pesquisa, os diferentes objetivos buscados entre as partes envolvidas. Tal posicionamento é chamado por alguns autores de critical multivocality (HOLLOWELL; NICHOLAS, 2008) e fornece condições para a avaliação científica de um trabalho feito sob o signo da "multivocalidade". "Tal multivocalidade crítica não é apenas ética como, também, 
cultiva uma interpretação arqueológica mais robusta, submetendo à diversas criticas e avaliações" (HOLLOWELL; NICHOLAS, 2008, p. 8).

Portanto, a possível tensão entre o trabalho arqueológico e a perspectiva étnica, no desenrolar de uma atividade que se pretende multivocal, não desqualifica o esforço do arqueólogo para o entendimento de conceitos de "passado" e de como esse passado é construído em uma epistemologia nativa, deste que a multivocalidade tenha uma postura reflexiva sobre si mesma. Uma atitude reflexiva, de olhar por diferentes ângulos, principalmente em contextos etnoarqueológicos, as relações arqueológicas possíveis entre passado e presente, pessoas e objetos, biologia e cultura, indivíduo e cultura (SHANKS, 2007). Ou, como no trabalho de Tim Ingold (2000), que mostra o uso de categorias nativas na reflexão arqueológica e antropológica, em uma clara referência ao aspecto relacional do modo de pensar ameríndio, em especial, as questões referentes aos assentamentos e a percepção do meio ambiente, que não é inata, mas se desenvolve junto à dinâmica da experiência.

A possibilidade de uma "perversão arqueológica", assim expressada por Viveiros de Castro, que ocorre quando as populações nativas usam sua continuidade histórica com o passado como meio de legitimação de sua existência no contexto político do mundo atual, com o intuito de assegurar a sua sobrevivência futura (VIVEIROS DE CASTRO, 2002a:341), ressalta o caráter de agentes históricos das populações nativas. Assim como elas atuam frente a pressões externas sobre sua própria adaptabilidade ao meio em que vivem (de discursos acadêmicos sociobiólogicos ou sob o signo do desenvolvimento sustentável), também atuam frente a verdades históricas (acadêmicas) exteriormente elaboradas. Nesse sentido tal "perversão arqueológica" não só contrasta com a auto-imagem de ciência da arqueologia, como também fornece elementos para sua reflexão enquanto tal. Essa atitude reflexiva permite entender, nos casos etnográficos, como circulam entre os agentes as diferentes formas discursivas. No caso, como as discursividades do arqueólogo circulam pelo coletivo indígena, assim como as discursividades indígenas circulam pelo coletivo dos arqueólogos. Assim, o passo que propus foi formular localmente, a partir das cenas abordadas, os campos múltiplos e as transações constituídas na prática arqueológica que, como vimos, não se resume à escavação em si. 
Portanto, podemos verificar na rede de saberes desenhada nos capítulos apresentados que apesar do profundo hiato (tanto temporal quanto teórico) entre arqueólogos, antropólogos e comunidades tradicionais, as reflexões críticas sobre a prática arqueológica são elaboradas, ainda que se questione a idéia de "público" envolvida nesta arqueologia. A realização de uma etnografia do trabalho arqueológico, coloca em contraste os diferentes públicos (ou vozes) e tende a apontar, no que se refere às comunidades tradicionais ou impactadas pelo trabalho arqueológico, a perspectiva de múltiplas abordagens sobre o patrimônio. A reflexão sobre esses processos possibilita assim, um aprofundamento epistemológico da arqueologia, contribuindo ao longo prazo para uma prática qualificada do arqueólogo, principalmente aquele que atua em comunidades tradicionais. 


\section{Bibliografia}

AGAMBEN, Giorgio. Medios Sin Fin. Notas sobre la política. Valencia: PRE-TEXTOS. 2001

ALBERT, Bruce. O Ouro Canibal e a Queda do Céu: Uma Crítica Xamânica da Economia Política da Natureza. Série Antropologia. Number 174. Brasília. Universidade de Brasília. 1995

ASHMORE,W ; KNAPP, A, B. (org). Archaeologies of landscape : contemporary perspectives. Malden, Mass: Blackwell, 1999.

APPADURAI, A. (Org.). The Social Life of Things. Cambridge: Cambridge University Press, 1986.

ARANTES, Antônio Augusto. A preservação de bens culturais como prática social. Revista de Museologia, São Paulo, v. 1, n. 1, p. 12-16, 1989.

ATTFIELD, J. Wild Things: Material Culture of Everyday Life. Oxford: Oxford Press, 2000.

AZANHA, Gilberto. As terras indígenas do Mato Grosso do Sul. São Paulo: Centro de Trabalho Indigenista (CTI), 2004.

AZARA, Felix. Voyages dans l'Amerique depuis 1781 jusqu'en 1801. Paris: C.A.Walckenarer, 1809.

BABADZAN, A. Les usages sociaux du patrimoine. Ethnologies Comparées, Vol.2, Mirroirs Identitaires, 2001.

BARRETO, Cristiana. A construção de um passado pré-colonial: uma breve história da arqueologia no Brasil. Revista USP. São Paulo, n.1, p. 23-51, dez., jan., fev. 19992000.

BEZERRA DE ALMEIDA, M. O público e o patrimônio arqueológico: reflexões para a arqueologia pública no Brasil. Habitus, Goiânia, v.1, n. 2, p. 275-295, jul.-dez. 2003.

BESPALEZ, E. Levantamento arqueológico e etnoarqueologia na Aldeia Lalina,

Miranda-MS: um estudo sobre a trajetória histórica da ocupação indígena regional. Dissertação (mestrado), USP, São Paulo, 2009.

BRUNO, Maria Cristina Oliveira. Arqueologia e antropofagia: a musealização dos sítios arqueológicos. Revista do Serviço do Patrimônio Histórico e Artístico Nacional. Rio de Janeiro, v. 31, p. 234-247, 2005. 
BOND, G. C.; GILliAM, A. (Orgs.). Social Construction of the Past. Londres: Routledge, 1994.

BOURDIEU, P.; LOÏC, J.D. Wacquant: an invitation to reflexive sociology. Chicago:

University of Chicago Press, 1992.

BOURDIEU, P. A economia das trocas simbólicas. São Paulo: Perspectiva, 1974. Homo academicus. Paris: Minuit, 1984.

CALLON, M.; LATOUR, B. Don't Throw the Baby Out with the Bath School! A Reply to Collins and Yearley. In: PICKERING, A. Pickering (Ed.). Science as Practice and Culture. Chicago, Chicago University Press, 1992. p. 343-368.

CARNEIRO DA CUNHA, M. M. "Culture" and culture: traditional knowledge and intelectual rights. Marc Bloch Lecture, 2004. (org) Patrimônio Imaterial e Biodiversidade In: Revista do Patrimônio Histórico e Artístico Nacional. No 32/ IPHAN. Rio de Janeiro, 2005.

CASTAÑEDA, Q. E. The "Ethnographic Turn” in Archaeology: Research Positioning and Reflexivity in Ethnographic Archaeologies. In: CASTAÑEDA, Q.; MATTHEWS, C. N. (Eds.). Ethnographic Archaeologies: Reflections on Stakeholders and Archaeological Practices. Lanham: Altamira Press, 2008.

CASTAÑEDA, Q, E; MATTHEWS, C. (org). Ethnographic Archaeologies:

Reflections on Stakeholders and Archaeological Practices. New york: Altamira Press. 2008.

CASTELNAU, Francis Comte de. Expedition dans les parties centrales de l'Amérique du Sud. Paris: P. Bertrand, 1851.

Expedição às regiões centrais da América do Sul. Trad. Olivério M. de Oliveira Pinto. São Paulo: Cia Editora Nacional, 1949. 378 p. (Col. Brasiliana,vol. 266-A T.II).

CÉSAR, A. L.; CAVALCANTI, M. C. Do singular para o multifacetado: o conceito de língua como caleidoscópio. In: CAVALCANTI, M.; BORTONI-RICARDO, S. M. 
(Orgs.). Transculturalidades, linguagem e educação. Campinas: Mercado de Letras, 2007.

DIAS, A. S. et al. O discurso dos fragmentos: sociocosmologia e alteridade na cerâmica guarani pré-colonial. Espaço Ameríndio, v. 2, p. 1-20, 2008.

DOBRES, M.; ROBB, J. E. Agency in Archaeology. Londres: Routledge, 2000.

DUPREE, L. The artificial small group and archaeological excavation. American Antiquity 20 (vol3):271, 1955.

EDGEWORTH, M. Multiple Origins, Development and Potential of Ethnografies of Archaeology. In: Ethnographies of Archaeological Practice. Lanham: Altamira Press, 2006.

EL-HAJ, N. A. Translating Truths: Nationalism, the Practice of Archaeology, and the Remaking of Past and Present in Contemporary Jerusalem. American Ethnologist 25 (vol2): p. 166-188, 1998.

FERNANDES, T. C. Vamos criar um sentimento: um olhar sobre a arqueologia pública no Brasil. Dissertação (Mestrado) - Museu de Arqueologia e Etnologia da USP, São Paulo, 2008.

FLORESCANO, E. El patrimonio cultural y la politica de la cultura. In: FLORESCANO, E. (Org.). El patrimônio cultural de México. Ciudad del México: Fondo de Cultura Econômica, 1993.

FOUCAULT, M. Microfísica do poder. Rio de Janeiro: Graal, 2004.

FUNARI, P. P. A.; ZARANKIN, A.; STOVEL, E. Global archaeological theory: contextual voices and contemporary thoughts. Nova York: Kluwer Academic/Plenum, 2005a.

FUNARI, P. P. A; ORSER Jr., C.; SCHIAVETTO, S. N. O.Identidades, discurso e poder: estudos da arqueologia contemporânea São Paulo: Annablume, 2005 b. 
FUNARI, P. P. A.; ROBRAHN-GONZALEZ, E. Ethics, capitalism and public archaeology in Brazil. In: HAMILAKIS, Y.; DUKE, Philip (Orgs.). Archaeology and Capitalism. Walnut Creek, v. 1, p. 137-149, 2007.

FUNARI, P. P. A. O papel da arqueologia na demarcação das terras indígenas e quilombolas. E-Premissas, v. 3, p. 1-15, 2008.

.Arqueologia e Patrimônio. 1. ed. Erechim: Habilis, 2007.

. Public archaeology from a latin american perspective. Public Archaeology.

Londres: James \& James Science Publishers, 2001. v. 1, p. 239-243.

GALLOIS, D. T. Patrimônio Cultural Imaterial e Povos Indígenas. Iepé: São Paulo. 2006.

GEERTZ,C. Local Knowledge. Nova York: Basic Books, 1983.

GELL, Alfred. Art and Agency: an Anthropological Theory. Oxford: Clarendon Press, 1998.

GIDDENS, A. New Rules of Sociological Method. Stanford: Stanford University Press, 1993.

GONZÁLEZ-RUIBAL, A. (Ed.). Arqueología Simétrica: Un Giro Teorico sin Revolucion Paradigmática (with commentary). Complutum, n. 18, p. 283-319, 2007.

GRÜNBERG, G. et al. Os kaiabi do Brasil Central: história e etnografia. São Paulo: Instituto Socioambiental, 2004.

GUIMARÃES NETO, R. B. A lenda do ouro verde: política de colonização no Brasil contemporâneo. Cuiabá: Unicen, 2002.

HARAWAY, D. Cyborgs to companion species: Reconfiguring kinship in technoscience. In: IHDE, D. (Ed.). Chasing Technoscience: matrix for materiality. Bloomington: Indiana University Press. 2003. p. 52-82.

HOBSBAWM, E.; RANGER, T. Introdução. In: A invenção das tradições. São Paulo: Paz e Terra, 1994. 
HODDER, I. Developing a Reflexive Method in Archaeology. In: (Ed.). Towards

Reflexive Method in Archaeology. p. 3-14. Cambridge: McDonald Institute, 2000. The Present Past. New York: Pica Press, 1982a. . Symbolic and Structural Archaeology. Cambridge: Cambridge University Press, $1982 b$. Post-Processual Archaeology. In: SCHIFFER, M. B. (Ed.). Advances in

Archaeological Method and Theory, n. 8. Nova York: New York Academic Press, 1985.

. Commentary: The Gender Screen. In: MOORE, J.; SCOTT, E. (Eds.). Invisible

People and Processes: Writing Gender and Childhood into European Archaeology. Londres: Leicester University Press, 1997.

(Ed.). Archaeological Theory Today. Cambridge: Polity Press, 2001.

. The maintenance of group identities in the Baringo district, west Kenya. In:

GREEN, D.; HASELGROVE, C.; SPRIGGS, M. (Orgs.). Social organization and settlement. BAR International Series (Supplementary) 47, part 1. Oxford: British Archaeological Reports, 1978.

HOLLOWELI, J; NICHOLAS, G. A critical assessment of ethnography in archaeology In: CASTAÑEDA, Q.; MATTHEWS, C. N. (Eds.). Ethnographic Archaeologies: Reflections on Stakeholders and Archaeological Practices. Lanham: Altamira Press, 2008

HOLTORF, C. Studing Archaeological Fieldwork in the Field. In: EDGEWORTH, M. (Org.). Ethnografies of Archaeological Practice. Lanham: Altamira Press, 2006. p. 81-94.

. Notes on the life history of a pot sherd. Journal of Material Culture, 7(vol1): p. 49-71, 2002.

KOJAN, D.; ANGELO, D. Dominant narratives, social violence and the practice of bolivian archaeology. Journal of Social Archaeology, 5(vol3): p. 383-408, 2005.

KNORR-CETINA, K.. The Manufacture of Knowledge. Oxford: Pergamon Press, 1981.

INGOLD, Tim. The Perception of the Environment: Essays on Livelihood, Dwelling and Skill. Londres: Routledge, 2000.

(Ed.).. Key Debates in Anthropology. Londres: Routledge, 1996. 
INSTITUTO SOCIO AMBIENTAL. Povos Indígenas do Brasil. São Paulo: ISA, $1996 / 2000$

.Povos Indígenas do Brasil. São Paulo:

ISA,2001/2005.

JONES, S. The Archaeology of Ethnicity: Constructing Identities in the Past and Present. Londres, Routledge, 1997.

LATOUR, B.; WOOLGAR, S. Vida de laboratório: a produção dos fatos científicos. Rio de Janeiro: Relume-Dumará, 1997.

LATOUR, B. Jamais fomos modernos. São Paulo: Editora 34, 1994. Ciência em ação. São Paulo: Unesp, 2000. . Reassembling the social: An Introducion on Actor-Network-theory. Oxford: Oxford Press, 2005.

LAYTON, R. Who needs the past? Indigenous values and archaeology. Londres: Routledge, 1994a. . (Org.). Conflict in the Archaeology of Living Tradition. Londres: Routledge, $1994 b$.

LENCLUD, G. Qu'est que c'est la tradition? In: DETIENNE, M. (Org.). Transcrire les mythologies. Paris: Albin Michel,.1994.

LILLEY, I. Archaeology, diáspora and decolonization. Journal of Social Archaeology, 6 (vol1): p. 28-47, 2006.

LIMA, T. A. (Org.). Revista do Iphan: Patrimônio Arqueológico - o desafio da preservação. Brasília: Iphan, n. 33, 2007.

MARCHEGIANI et al. PASADO, FUTURO Y PRESENTE: LA CONSTRUCCIÓN DE LA IDENTIDAD CULTURAL EN LA COMUNIDAD INDIA QUILMES. Museo Etnográfico "Juan B. Ambrosetti”, Universidad de Buenos Aires. Buenos Aires. 2007

MARTIN, Andrew. Agents in Inter-Action: Bruno Latour and Agency. Journal of Archaeological Method and Theory, v. 12, n. 4, p. 283-311, dez. $2005 .$.

MILLER, D. Material Culture and Mass Consumption. Oxford: Blackwell, 1987. . Materiality. Durham: Duke University Press, 2005. 
MILLION, T. Developing an Aboriginal archaeology: receiving gifts from White Buffalo Calf Woman. In: SMITH, C; WOBST, H. (Eds.). Indigenous Archaeologies:

Decolonizing Theory and Practice. New York: Routledge, 2005. p. 43-55.

MÜlleR, R. P. Os Asuriní do Xingu: história e arte. Campinas: Editora da Unicamp, 1990.

MESKELL, L.; PREUCEL, R. (Eds.). A Companion to Social Archaeology. Oxford:

Blackwell, 2004.

NEVES, E. G.; GREEN, L.; GREEN, D. Indigenous Knowledge and Archaeological Science: The Challenges of Public Archaeology in the Reserva Uaçá. Journal of Social Archaeology, vol. 3, n. 3, p. 366-398, 2003.

NOELLI, F. S.; FERREIRA, L. M. A persistência da teoria da degeneração indígena e do colonialismo nos fundamentos da arqueologia brasileira. História, Ciências, Saúde. Manguinhos, v. 14, p. 1239-1264, 2007.

OAKDALE, S. I foresee my life: the ritual performance of autobiography in an Amazonian Community. Lincoln: University of Nebraska Press, 2005.

OLIVEIRA, Aldeides et al. Arqueólogos e populações ribeirinhas: uma etnografia do trabalho de campo. In: Cadernos do Centro de Filosofia e Ciências Humanas, Belém (vol15) 37-60, 1988.

OLIVEIRA, Jorge; PEREIRA, Levi Marques. Duas no pé e uma na bunda: da participação Terena na guerra entre o Paraguai e a Tríplice Aliança à luta pela ampliação dos limites da Terra Indígena Buriti. Revista Eletrônica História em Reflexão. Dourados, v. 1, n. 2, jul./dez. 2007.

OLIVEIRA, R. C. de. Aspectos demográficos e ecológicos de uma comunidade Terena.

Boletim do Museu Nacional. Rio de Janeiro, Museu Nacional, v.18, 25 p., set. 1958.

. Do índio ao bugre. Rio de Janeiro: Francisco Alves, 1976. (Ciências Sociais).

. Dualismo Terena. In:

Enigmas e soluções: exercícios de etnologia e de crítica. Rio de Janeiro: Tempo Brasileiro; Fortaleza: UFCE, 1983. p. 76-83.

(Biblioteca Tempo Universitário, 68.)

. Matrimônio e solidariedade tribal Terêna. In: Enigmas e soluções: exercícios de etnologia e de crítica. Rio de Janeiro: Tempo Brasileiro; Fortaleza: UFCE, 1983. p. 31-53. (Biblioteca Tempo Universitário, 68) Publicado também em Revista de Antropologia. São Paulo: USP, v.7, n.1/2, 1959. O processo de assimilação dos Terena. Rio de Janeiro: Francisco Alves, 1976. 
. Urbanização e tribalismo: a integração dos Terena numa sociedade de classes. Rio de Janeiro: Zahar, 1968.

.Sobre o pensamento antropológico. Rio de Janeiro: Tempo Brasileiro. 1988.

OLSEN, B. Material Culture after Text: Re-Membering Things. Norwegian

Archaeological Review 36(vol2), p. 87-104, 2003.

. Scenes from a troubled engagement: Post-structuralism and material culture

studies. In: TILLEY, C. et al. (Eds.). Handbook of Material Culture. Londres:

Sage, 2006. p. 85-103,.

ORTNER, S. B. Theory in anthropology since the sixties. Comparative

Studies in Society and History. n. 26, p. 126-166, 1984.

PEIRANO, M. A favor da etnografia. Rio de Janeiro: Relume-Dumará, 1995.

POLONI, R. J. A etnoarqueologia no Brasil: ciência e sociedade no contexto de redemocratização. Dissertação de Mestrado, Universidade do Algarve, Faro. 2008

POLITIS, G. Acerca de la Etnoarqueología en América del Sur. Horizontes

Antropológicos. Porto Alegre, ano 8, n. 18, p. 61-91, 2002.

PREUCEL, R. W. The postprocessual condition. Journal of Archaeological Research, N. 3, 1995.

PRICE, R. First Time: the Historical Vision of an Afro-American People. Baltimore: The John Hopkins University Press, 1983.

Meditação em torno dos usos da narrativa antropológica contemporânea.

Horizontes Antropológicos. Porto Alegre, ano 10, n. 21, p. 293-312, jan./jun. 2004.

RIBEIRO, B. Desenhos semânticos e identidade étnica: o caso Kayabí. In: RIBEIRO, B. (Coord.). Suma Etnológica Brasileira 3: arte índia. Petrópolis: Vozes, 1986. p. $265-$ 86.

SAHLINS, M.. O pessimismo sentimental e a experiência etnográfica: por que a cultura não é um objeto em vias de extinção. Parte I. Mana, v. 3, n. 1, p. 74-73, 1997.

SCHAAN, D. P. Arqueologia, público e comodificação da herança cultural: o caso da cultura Marajoara. Revista Arqueologia Pública. São Paulo, n.1, p. 19-30, 2006.

- Múltiplas vozes, memórias e histórias: por uma gestão compartilhada do patrimônio arqueológico na Amazônia. Revista do IPHAN: Patrimônio Arqueológico - o desafio da preservação. Brasília, n. 33, p. 109- 136, 2007.

SCHIFFER, M. B; MILLER, A, R. The Material Life of Human Beings: Artifacts, Behavior, and Communication. Londres/New York: Routledge, 1999. 
SCHMIDT, M. Informações sobre os índios Kayabi. Terra Indígena. Araraquara, Centro de Estudos Indígenas, v. 10, n. 69, p. 51-5, out./dez. 1993.

. Los Kayabi en Mato Grosso. Revista Sociedad Científica del Paraguay. Assunção, n. 5, 1942.

Os Aruaques, mimeo - 1917

SCREVEN, C.G. Educational evalution and research in museuns an Curator 27 (vol2):

147-65.

. Visitor Studies in the U.S. Museum 178 (vol2)

SHANKS, M. Symmetrical Archaeology, World Archaeology 39(vol4), 2007.

SHANKS, M.; TILLEY, C. Re-constructing archaeology. Cambridge: Cambridge University Press, 1987.

Archaeology into the 1990's (with comments and response). Norwegian

Archaeological Review, ano 22, n. 1, 1989.

SILLIMAN, S. W. Culture Contact or Colonialism? Challenges in Archaeology of Native North America. American Antiquity, 70 (vol1): p. 54-74, 2005.

SILVA, F. A. Mito e arqueologia: a interpretação Asurini do Xingu sobre os vestígios arqueológicos encontrados no parque indígena Kuatinemu- Pará. Porto Alegre.

Horizontes Antropológicos, ano 8, n. 18, p. 175-187, 2002.

A tecnologia e seus significados: um estudo da cerâmica dos Asurini do Xingu e da cestaria dos Kayapó-Xikrin sob uma perspectiva etnoarqueológica. 2000 Tese (doutorado) - USP, São Paulo.

SILVA, F. A. ; BESPALEZ, Eduardo ; STUCHI, F. F. ; PONGET, F. C. . Arqueologia, Etnoarqueologia e História Indígena - um estudo sobre a ocupação indígena em territórios do Mato Grosso e Mato Grosso do Sul: a terra indígena Kayabi e a aldeia Lalima. Revista do Museu de Arqueologia e Etnologia, v. 17, p. 509514,2007 
. Arqueologia, Etnoarqueologia e História Indígena. Um estudo sobre a trajetória de ocupação indígena em territórios do Mato Grosso e Mato Grosso do Sul: A T.I. Kaiabi e a Aldeia Lalima. Relatório de pesquisa - FAPESP.2009

SILVA, Vagner Gonçalves da. O antropólogo e sua magia. Trabalho de campo e texto etnográfico nas pesquisas antropológicas sobre as religiões afro-brasileiras. São Paulo: EDUSP, 2006.

SMITH, C.; WOBST, H. C. Indigenous Achaeoloies: Decolonizing Theory and Practice. Londres: Routledge, 2005.

SOUZA, José Luiz. A (In)visibilidade dos lugares Kadiwéu: contribuições da geografia cultural para o estudo de populações indígenas. Espaço e Cultura, Rio de Janeiro, $\mathrm{n}$. 23, p. 53-66, jan./jun. 2008.

SOUZA, A. M. História da Arqueologia Brasileira. Pesquisas. São Leopoldo-RS, n. 46, p. 11- 136, 1991. (Série Antropologia)

STARK, M. P. Re-fitting the "cracked and broken facade": the case for empiricism in postprocessual archaeology. In: YOFFE, N.; SHERRAT, A. (Orgs.).. Archaeological theory: who sets the agenda? Cambridge: Cambridge University Press, 1993.

STEINEN, K. V. Entre os aborígenes do Brasil central. Prefácio de Herbert Baldus. Trad. Egon Schaden. São Paulo: Departamento de Cultura, 1940.

STENGERS, I. A invenção das ciências modernas. São Paulo: Editora 34, 2002.

STRATHERN, M. The Limits of Auto-Anthropology. In: JACKSON, A. (Ed.). Anthropology at Home. Londres: Tavistock, 1987. p. 16-37. . The Gender of the Gift: Problems with Women and Problems with Society in Melanesia. Berkeley: University of California Press, 1988. After Nature: English Kinship in the Late Twentieth Century. Cambridge: Cambridge University Press, 1992.

TAUNAY, A. D’Escragnolle. Entre nossos índios Chanés, Terenas, Guanás, Kinikinaus, Laianas, Gatós, Guaycurus, Caingangas. São Paulo: Melhoramentos, 1940. . História das Bandeiras Paulistas. T. II. São Paulo: Melhoramentos, 1951. 
TAYLOR, A. C. L’oubli des morts et la mémoire des meurtres: expériences de l'histoire chez les Jivaro - Terrain 28, 1998.

TEDLOCK, D. The Spoken Word and the Work of Interpretation. Filadelfia:

University of Pennsylvania Press, 1983.

TILLEY, C. (Ed.). Interpretative Archaeology. Oxford: Berg, 1993.

THOMAS, D. H.; COLLEY, S. Skull Wars: Kennewick Man, Archaeology, and the Battle for Native American Identity. Nova York: Basic Books, 2001.

THOMAS , N. C. Colonialism's Culture: Anthropology, Travel and Government.

Victoria: Melbourne University Press, 1994.

TORRENCE, R.; CLARKE, A. The archaeology of difference: negotiating cross-cultural engagements in Oceania. Londres; Nova York: Routledge, 2000.

TRAVASSOS, E. A tradição guerreira nas narrativas e nos cantos Caiabis. In: COELHO,

V. P. (Org.). Karl von den Steinen: um século de antropologia no Xingu. São Paulo: Edusp/Fapesp, 1993.

Xamanismo e música entre os Kayabi. 1984. 357 p. Dissertação (Mestrado).

UFRJ, Rio de Janeiro.

UCKO, P. (Ed.). Theory in Archaeology: a world perspective. Londres: Routledge,1995.

VAN REYBROUCK. D.; JACOBS, D. The Mutual Constitution of Natural and Social Identities During Archaeological Fieldwork. In: Ethnographies of Archaeological Practice. Lanham: Altamira Press, 2006.

VANPOOL, C. S.; VANPOOL, T. L. (Eds.). Essential Tensions in Archaeological

Method and Theory. Salt Lake City: University of Utah Press, 2003. . The scientific nature of postprocessualism. American Antiquity, n. 64, 1999.

VIDAL. L. Grafismo indígena: estudos de antropologia estética. São Paulo: Studio Nobel / FAPESP, 1992. 
VILLAS BOAS, O.; VILLAS BOAS, C. Xingu: os Kayabi do rio São Manoel. Porto Alegre: Kuarup, 1989.

VIVEIROS DE CASTRO, E. A inconstância da alma selvagem. São Paulo: Cosac \& Naify, 2002a. Nativo Relativo. MANA 8(vol1): 113-148. 2002b

WAGNER, R. The Invention of Culture. Chicago, The University of Chicago Press, 1981.

WATKINS, J. Indigenous Archaeology: American Indian Values and Scientific Practice. Walnut Creek, CA: Altamira Press, 2000.

WEBMOOR, T. Un giro más tras el "giro social": El principio de la simetría en arqueología, for González-Ruibal, A. (ed.) "Arqueología Simétrica. Un Giro Teorico sin Revolucion Paradigmática", for Complutum 18, 296-304. 2007 a.

.What about "one more turn after the social" in archaeological reasoning? Taking things seriously. World Archaeology, 39(4), p. 547-562, $2007 \mathrm{~b}$.

WEISS, H. E. Para um dicionário da língua Kayabi. 1998 Tese (Doutorado) - USP, São Paulo.

Witmore, C. L. Archaeology and modernity, or archaeology and a modernist amnesia? Norwegian Archaeology Review 39(vol1), p. 49-52, $2006 \mathrm{a}$.

. Vision, Media, Noise and the Percolation of Time: Symmetrical Approaches to the Mediation of the Material World. Journal of Material Culture 11(vol3), p. 267$292,2006 b$.

. Symmetrical Archaeology: Excerpts of a manifesto. World Archaeology 39(vol4), 2007.

ZEDEÑO, Maria Nieves. Landscapes, Land Use, and the History of Territory Formation: An example from the Puebloan Southwest. Journal of Archaeological Method and Theory. vol. 4, n. 1, 1997

ZIMMERMAN, L. J. Human bones as symbols of power: aboriginal American belief systems toward bones and grave-robbing archaeologists. In: LAYTON, R. (Ed.). Conflict in the archaeology of living traditions. Londres: Routledge, 1994. p. 211216. 
ANEXOS 


\section{ANEXO 1. Diálogo entre cientistas.}

Arqueólogo2: tem os sítios de tapera, que são já fizemos em alguns sítios uma com coleta os relatos etnohistóricos deles, que também tem cerâmica.

assistemática em um setor, só para termos

Arqueólogo3: É cerâmica do período do contato?

uma amostra desse material. $\grave{E}$ muito

Arqueólogo1: tem algumas...

Arqueólogo2: tem muito material.

Arqueólogo1: Eu falei para ti que talvez os sítios não fossem tão grandes, mas os sítios guarani são gigantescos.

Arqueólogo2: O que aconteceu também é que tem muita sobreposição (sucessivas ocupações) nos sítios.

Arqueólogo1: Mas em comparação com os sítios da Amazônia eles não são grandes.

Arqueólogo2: Eu também acho que não é um sítio só, acho que temos um palimpsesto de ocupação e que tem muito material misturado.

$E$ que nesse momento estamos definindo os sítios...mas, essa definição é para um primeiro momento, só com o levantamento intensivo, com trabalho de muitos anos, para definir esses sitios.

\section{diagnóstico...}

Topografo1: Então mapeamos as áreas que vocês coletaram para constar no mapa.

Arqueólogo2 : O trabalho está muito legal, eu perguntei coisas diferentes para os sitios e fizemos ações diferenciadas, até para termos uma idéia variada do que acontece nos sítios. Só que nós tivemos muita sorte, caímos em cima de sítios com materiais diferenciados. $E$ essas taperas, eu não imaginava que iríamos achar material cerâmico e ponta de flecha em metal. Enfim, temos referências superlegais para chamarmos de etno-histórico mesmo! Ai podemos mostrar a diversidade de ocupação dessa pequena área. E tem material em todo lugar, a aldeia inteira é uma 'sitiolândia'. Então é trabalho para muito tempo.

Topografo1: Esses sítios estão dentro da mesma área?! Então, na verdade, a aldeia pode ser considerada como um grande sítio Topografo1: Aquela idéia de coleta sistemática ainda existe?

Arqueólogo 1: Tem, mas vamos fazer só em um setor.

Arqueólogo2: Vamos setorizar alguns sitios para fazermos, senão vai ser muito material. Também os sítios estão muito perturbados, preta da Amazônia onde encontramos uma existe muita ação de arado. Por isso que nós dispersão imensa, no caso dos guarani. 
Porque temos isso, esse é o modelo guarani, é fazer cerâmica, eles não fazem mais. A não ser o modelo tupi. A população cresce e eles vão nas outras aldeias. Então poderemos construindo, os grupos domésticos vão se trabalhar toda a linha de tempo desse jeito. formando e a mancha de cacos cerâmicos vai Como diagnóstico da área está ótimo.

se espalhando. Isso deve ter um contexto de Arqueólogo1: E tem tudo a ver com os dados ocupação muito longo, é por isso que temos históricos.

essa massa de material espalhada pelo sitio. Arqeuologo2: É, tem tudo a ver. Está tudo Arqueólogo1: Também acho. fechando, as coisas estão casando.

Arqueólogo2: Agora temos esses sítios E sem contar, que metodologicamente, pequenos que são da tradição pantanal, que estamos fazendo todo o trabalho de são mais setorizados, e isso é bom para arqueologia em terra indígena, que é contrapor com esse padrão de implantação, literalmente fazer arqueologia em área essa diversidade. Eles são diferenciados, eles indígena. Que envolve todo o processo de parecem menores, estão num horizonte mais interlocução, de todo dia ouvir o que os índios recente. Os sítios de tapera são maravilhosos, tem a dizer. Isso tem que fazer parte da pois estão na memória dos índios ainda e metodologia de trabalho, isso te atrasa e estamos encontrando cerâmica neles também. adianta ao mesmo tempo. Ficamos oscilando O que é legal, pois eles perderam o jeito de neste processo todo. 


\section{Anexo 2. Diálogo com o Cacique Terena.}

Arqueólogo2: É claro que eu quero ter toda uma boa relação com todo mundo, mas o que eu quero ter bem esclarecido até pra mim é assim: Quem é a autoridade oficial na aldeia? São vocês, então é pra vocês que a gente vai se reportar sempre oficialmente, mas agora é claro que eu quero conversar com todo mundo, quero visitar a casa de todo mundo e quero poder contribuir com a comunidade como um todo. O que nós não queremos, e isso tem que ficar bem claro para vocês, é que reconhecemos a sua autoridade oficial. E que isso para nós é importante, se vocês nos apóiam a gente fica tranqüilo. Porque a Funai reconhece vocês (como autoridade) e eu estou reconhecida pela Funai.

Cacique: O companheiro ali (uma outra liderança) não acha por bem (eu) fazer presença com eles (conselho da Campina), porque senão vai dar mais força pra eles, na qual eles querem. Porque lá, não está todo o povo daquele lado (setor da Campina), mas isso não impede de vocês ficarem falando (de irem lá)...

Arqueólogo2: Claro, eu também acho que a gente tem que ter uma relação boa com todo mundo... Mas, você pode explicar bem pro conselho que eu conversei com o chefe de posto. Agora... reconhecemos que vocês são a autoridade oficial da aldeia. E é para vocês, e sempre pra ti, como cacique, que eu vou me reportar, que eu vou conversar as questões. Porque se vocês são reconhecidos pela Funai, então é com vocês que eu tenho que acertar as coisas do projeto. Assim eu fico até mais tranqüila de saber isso, porque eu não ia querer ficar me dividindo o tempo inteiro, assim não ia dar...

Foi quando eu perguntei para o chefe de posto: quem é realmente reconhecido pela Funai? E ele me disse que é esse o conselho (do setor da Sede) que realmente é reconhecido pela Funai...mas isso não impede de andarmos pela aldeia toda e nós mantermos uma relação boa com todo mundo...mas então tu não vai com a gente?

Cacique: Não...

Arqueólogo1: Mas a gente reconhece a sua autoridade, e a gente agradece muito todo esse respaldo... e aí, agora vocês decidem quem vem trabalhar com a gente. 


\section{Anexo3}

\section{Conflito com a vizinha- Aldeia} Terena.

Arqueólogo 2: Você acha que pode cortar essa área, porque essa área é sua? Liderança Indígena/auxiliar de campo: é, é minha...

Arqueologo3: Você foi lá conversar com ela?

Arqueólogo2: Eu tentei falar com ela... mas ela estava muito agressiva... ela não quer, ela não tem interesse, ela não quer nem saber!

...que ela não foi avisada pelo cacique e não importa o que eu disser que ela não vai deixar (pesquisarmos) que essa aqui é a plantação dela...ela acha que tem que ser preservada (os vestígios de cacos cerâmicos) e que ninguém pode pegar nada...eu disse então, que a senhora conversa com o cacique que ele vai the explicar...

Arqueológol: E os piquete estão bons?

Topogrfol: Estão...

Arqueólogo 2: Então é isso... se o seu Manuel esta dizendo que esse lugar é dele então...mas o senhor conversa com ela depois e diz que essa área é sua e foi por isso que a gente pegou, por que o senhor disse que podia, senão ela vai reclamar la para o cacique...

Liderança Indígena/auxiliar de campo: Não tem o que reclamar, já esta tudo ajustado ai pra trabalhar...

Arqueologo 2: É que a gente não quer briga...eu disse pra ela que tudo bem, que se ela não quer... 


\section{Anexo 4}

\section{Entrevista com Ancião1 e Ancião2, Aldeia Lalima}

Arqueólogo3: Eu sou o arqueólogo3, não sei se falaram de mim? Estou Aqui conversando com as pessoas. A idéia, Ancião1, desse trabalho é de que o senhor conte um pouco de sua história de vida pra gente. Aí eu vou registrar, gravar a nossa conversa...assim,quando alguém quiser saber um pouco da historia de Lalima está registrado, dá para saber.

Ancião1: (história) do começo?

Arqueólogo3: Do começo.

Ancião1(0:04:44) Já andou tudo por lá (no setor sede da aldeia)?

Arqueólogo3: Já conversei com o a liderança3, o seu antigo cacique e até com a Dona ana que veio pra cá... É ela que faz as ervas aqui?

Ancião1: É, para gravar?

Arqueólogo3: Pode? Se o senhor, não quiser não precisa.

Ancião1: (pode) eu vou contar o que eu sei!Quando me conheci por gente nós morávamos aqui... Pirizal é como se chama...A gente ia buscar água no rio... só água...tempo de chuvarada nos tomávamos água desse córrego ai....de manhã a gente cagava no rio e ficava.Cada um com o seu potinho de barro... A panela era de barro... Prato de barro...

Arqueólogo3: Tudo o que vocês tinham era de barro?

Ancião1 :As colheres eram de pau... fazia igual as colheres compradas... Tinha palha... Cada um com uma purunguinha, igual essa aqui que está cortada, cheio d'água... Pra tomar água... Só no rio a gente pegava água... Tomava banho e pegava água...

Arqueólogo3: E quantas famílias tinham naquela época, tinham muitas famílias aqui?

Ancião1: Aqui não alcançava quinze famílias... Era só aqui mesmo que tinha gente...

Ancião2: Boa Tarde.

Arqueólogo3: Boa Tarde, tudo bom com o senhor?

Ancião2 ::Tudo bem.

Arqueólogo3: E como chamava esse lugar?

Ancião1: Pirizal... Ai que foi aumentando mais foi chegando mais gente... Foram trabalhando na comarca... Foram fazendo barraca... Foi chegando mais gente...

Arqueólogo3: Foi chegando de onde?

Ancião1(00:08:50): Ai do outro lado... Das fazendas... Vinham correndo pra cá ${ }^{18} \ldots$

18 Nesse momento da entrevista

Anciãol faz rapidamente uma

menção Implícita de um confeito,

que não fica nítido na gravação.
Veio muita gente... Muita gente...

Esses dias estava contando e só dava umas treze ou quatorze famílias só que tinha... Mas era só Kadiwéu, não tinha Terena --hoje já está misturado - não tinha Guaná, não tinha Kinikinau e origem de paraguai(guarani)...

Nosso engenho de moer cana era pra lá... Feito de pau...era dois. Fazia rapadura, fazia açúcar da cana... Fazia bastante vendia pra Miranda... na aquele tempo era só trilheiro, não tinha estrada... era só trilha até Miranda.

$\mathrm{E}$ os remédios daqui era só remédio do mato... aqui não tinha farmácia..

Arqueólogo3: E quem fazia remédio?

Ancião1:Qualquer um desses mais velhos fazia... Ia ao mato, arrancava a raiz e sabia... Isso é pra febre, dor de barriga, isso aqui pra maleita... Cada raiz era pra uma coisa... Dor de cabeça, pra cãibra, tudo eles sabiam.

Arqueólogo3: E tem alguém que ainda faz?

Ancião1:Tem...

Arqueólogo3: Quem que faz?

Ancião2(12:45): Aqui mesmo tem um com nós... A mulher da liderança2 ...

Arqueólogo3:A liderança2 disse que era neto de purungueiro, é isso?

Ancião2 : É, nóis... Meu pai era purungueiro... As duas filhas de meu pai... Minha tia purungueira morava ali...essa que tinha mais força. Aqui começou a aldeia... Quando me conheci por gente,aqui, eu contei onze casas só.

Arqueólogo3: Aqui chamava como?

Ancião2: Pirizal mesmo... ali naquelas casas próximo ao mangueirão bem na curva ali, onde está aquele mato ali tem um pé de piúva ( ipêamarelo), ali tem o córrego do Lalima

Arqueólogo3: Porque que chama Lalima?

Ancião1: Lalimaga...... No idioma kadiwéu. Arqueólogo3: E o que significa "lalimaga" Ancião1: "Quando chegaram aqui o sol ia entrando."

Arqueólogo3: Bonito. E a Mata do Urubeba tinha gente naquela época?

Ancião2: Era só lá que tinha gente... Aqui não tinha...

Arqueólogo3: E quem estava lá?

Ancião2: Naquele tempo tinha só um primo meu que morava lá... Lá na igreja, lá em cima perto da caixa d'água...

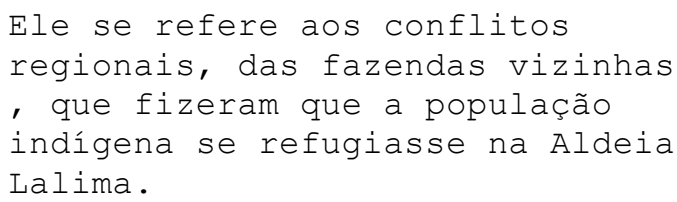


Arqueólogo3: Mas era lá o mato da Urubeba?

Ancião2: Era...

Arqueólogo3:Tinha quantas famílias?

Ancião2: Na Mata do Urubeba, lá, tinha quatro só... Quatro famílias. Eram quatro casas só... Era por ali a igreja católica... Julio... Leonardo...Seis famílias!... Mané .... Tia Ana .... José .... Tinha o Purungueiro, também...e só.

Arqueólogo3: E aonde mais tinha gente?

Ancião2: Pra lá só mato... Pra lá o rio...

Arqueólogo3: Pra lá é mato?

Ancião2: Não pra lá é campo,o rio abaixa ali, anda dois quilômetros...

Arqueólogo3:Morava alguém no campo?

Ancião2:Não...

Arqueólogo3:Tem o marco ali, não tem?

Ancião2:Tem...

Arqueólogo3: Como que é o marco?

Ancião2 começa a fazer um desenho no chão mostrando o formato do Marco

Arqueólogo3: Era feito do que os marcos?

Ancião2: Cerne de aroeira...

Arqueólogo3:Quem foi que colocou os marcos?

Ancião2 (00:18:30):Ah, não sei, faz muito tempo... Esse marco que tá fincado é dessa grossura... ele vai indicando ( a linha de divisão) e vai retinho, passa em cada fazenda, tem um péde-boicaúva, segue a linha da placa da fazenda até chegar no marco. A divisa no rio, tinha um marco me mostraram, cheguei a conhecer, era um cerne dessa grossura, mas estava no meio das moitas taquaruçu.De certo eles souberam e acharam(os marcos), os fazendeiros mandaram derrubar tudo aqueles taquaruçu meteram óleo e queimou, acabou. Mas pra isso tem dois pés de figueiras para marcar (o local).

Arqueólogo3: E está marcado os dois pés de figueira?

Ancião2: Não, só tinha para ...

Arqueólogo3: Localizar

Ancião2: É

Arqueólogo3 (00:20:15): E lá na mata do Urubeba que tipo de índio morava lá?

Ancião2: Na mata do Urubeba era só Terena... E aqui no Pirizal era só Cadiweu...

Ancião2: Quando eu me conheci por gente, lá no Urubeba era meio misturado, já... Terena com Laiana...Só aqui no pirizal que tinha Cadiweu. Dali da igreja dos crentes pra cima, pra campina, é tudo Souza... Tudo parente... Tudo somo parentaria... Tem só um que é índio guarani...

Arqueólogo3:Mas ele chegou agora ou faz tempo?

Ancião1:Faz tempo...

Ancião2: No nosso tempo não existia essa coisa de butina ...A gente se vestia com couro de vaca...chinelo de couro.

Arqueólogo3:Mas tinha camiseta, tinha calça?
Ancião2: Tinha calça... A gente ia ao mato tomar chá de capim cidreira... Adoçava com mel de abelha...

Arqueólogo3:E agora não?

Ancião2: Agora não... Graças a Deus a gente passa mais ou menos... Nossa mãe e pai acordavam de madrugada pra catar mandioca... Bem cedo saia pra procurar abelha adoçar a água pra nós... E foi por isso que nós não aprendemos a ler... Quando a gente pegou idade pra estudar, tinha professora no posto...

Arqueólogo3(00:23:36):Então vocês aprenderam a ler?

Ancião2: Não, fomos um dia só na escola... Fomos uns oito dias só na escola... Ai meu pai me tirou pra trabalhar...

Arqueólogo3: Qual a diferença entre os terenas e os cadiweu?

Ancião2: A diferença é pouca... É que nos não une, não procura união...

Arqueólogo3: Porque que não?

Ancião2: Não sei... É a natureza... Porque cada um tem a sua natureza...

Arqueólogo3: Como que é a natureza do cadiweu?

Ancião2: A diferença, por exemplo, é que nos todos aqui somos Cadiweu eles lá são Laiana, nós não proseia , mas pode passar por ali...

Arqueólogo3: E como que é a natureza do branco?

Ancião2: O branco tem muita leitura... deste cedo vai pra escola

Arqueólogo3: A diferença do cadiweu para o terena?

Ancião2: Ah, é muita... agora, faz muitos anos depois que terminou a guerra, não foram lá pra baixo trabalhar na divisa dos cadiweu. Agora é tudo diferente, é tudo civilizado esses índios aí. Cada rapaz loiro...moça...

Na outra Aldeia, o senhor dá um pulo lá pra ver como que é... lá eles falam só idioma.

Arqueólogo3: Qual que é o nome da aldeia lá?

Ancião2(00:26:06): Aldeia Cadiweu

Arqueólogo3: É longe daqui?

Ancião2: Não, uns dois dias e meio de carro, fica na costa do rio Paraguai aqui embaixo.

Arqueólogo3:Quais as taperas que tinham aqui?

Ancião2: Só tinha essa aqui... Tapera do pirizal...

Arqueólogo3:E antes do Pirizal o que é que tinha?

Ancião2: Deste que me conheci por gente, que eu sei era só o pirizal...

Arqueólogo3:Antes do pirizal tinha outras pessoas que moravam aqui, tinha outra tapera?

Ancião2: Não... Só nós mesmos...

Arqueólogo3: Então, os primeiros que chegaram aqui... Não tinha ninguém antes?

Ancião2 :Não...

Arqueólogo3: Vocês aprenderam algum mistério de índio? 
Ancião2: Não...

Arqueólogo3: Mas o seu pai era purungueiro?

Ancião2: Era, mas não ensinou...

Arqueólogo3: Porque vocês não quiseram ser purungueiro?

Ancião1É muito difícil...

Arqueólogo3:Por quê?

Ancião1:Tem que falar muito idioma...

Ancião2: Tem que compreender como que é o idioma e saber chamar... Com o purungo vem os companheiros, compreende?!

Arqueólogo3: Não...

Ancião2: Quando meu trabalhava via o companheiro, os guia... Do meu pai era macaco e lebre. A purungueira de lá tinha mais companheiro, mais guia.

Arqueólogo3: O que fazia os purungueiro?

Ancião2: Curava gente...

Arqueólogo3: Faziam cerâmica também?

Ancião2: Não, que dizer ...passou um tempo veio alguém da cachoeirinha, vinha muita gente tratar com ela.

Arqueólogo3: Quem fazia os potes?

Ancião2: Quem fazia era mulher que morava lá em cima. Mulher e homem faziam, também... nossos potes eram de barro, terra...

Arqueólogo3: Eram com desenho?

Ancião2: Não... Fazia do jeito que quisesse... Era só pedir...

Arqueólogo3: E o senhor fazia pote?

Ancião2: Não...

Arqueólogo3: O senhor fazia pote?

Ancião1: Não, também...

Arqueólogo3: O senhor já viu desenho no pote?

Ancião1: Vi...

Arqueólogo3: O pessoal fazia desenho aqui?

Ancião1: Fazia... Mas não deixava ninguém ver... Arqueólogo3: Por quê?

Ancião1: Porque tem um mistério, não pode ver... quando você vem pra ver eles tampam o pote novo que tão fazendo, não pode pegar vento. E pra cá também era só eles que ficava. Não podia ninguém ver... era muito delicado..

Arqueólogo3:O que significava os desenhos? O que dizia os desenhos?

Ancião1: Nome do lugar... A pessoa encomendava um e fazia com o nome da pessoa desenhado. Mas foram acabando (o processo de fabricação)...

Arqueólogo3: Ma quem fazia?

Ancião1: Os cadiweu e os Terenas faziam...

Arqueólogo3: Eram iguais os potes?

Ancião1:Era...

Arqueólogo3:Igualzinho, Igualzinho?

Ancião1: igualzinho.

Arqueólogo3: E quem ensinou para eles?

Ancião1: A gente não sabe...

Arqueólogo3 (00:33:00): Esses cacos ai, que acha ai na terra?
Ancião1: Isso faz tempo que eles andavam ai... correndo da revolta, morando em qualquer parte. Jogava em qualquer parte... Pra cá tem uma baia ai embaixo... lá no laranjal, naquelas casas lá, era ali que eles moravam ... Chama baia do laranjal...

Arqueólogo3:Ah, os paraguaios... Moravam paraguaios lá?

Ancião1 e Ancião2: Não... era nos Índios, escondido dos paraguaios.

Arqueólogo3:E que tipo de índio?

Ancião2: Cadiweu, mesmo... Morava lá na tapera do laranjal... Fica meio retirado do rio... Perto de um lagoão... Curicho do Laranjal ...

Arqueólogo3: Morava gente lá?

Ancião1: Não...Os índios se escondiam lá dos paraguaios...amoitado

Arqueólogo3: Aqui ta cheio de pedaço de pote?

Ancião2: Ta...

Arqueólogo3: Aqui tem um pedaço de pote antigo...Isso é barro?

Ancião2: É... com isso daqui que fizeram a igreja católica, Levantaram o encaixamento dela...

Arqueólogo3:Encaixamento... O que é isso?

Ancião1: Levantar ela até essa altura do chão( cerca de meio metro), pra formar a igreja. Chama adoubro ... Esses adoubros foram feitos bem ai... Faziam bem ai, onde tem uma brota ( d'agua)... Eles têm forma, como rapadura... Fica bem quadradinho... Da largura desse banco $( \pm 30 \mathrm{~cm}) \ldots$

Arqueólogo3: E onde ficava isso?

Ancião1: Na vazante...

Arqueólogo3: No córrego?

Ancião1: Num correguinho...

Arqueólogo3: Como se chama o correguinho?

Ancião2: Adoubro... Córrego do Adoubro...

Ancião1: A mistura dele é capim...tem que misturar até dá ponto.

Arqueólogo3 :Com o barro desse córrego se faz tijolo

Ancião1: È...tem que amacia que nem tijolo

Arqueólogo3: E tem casa que foi feito com isso?

Ancião2: Ah, tem, mas não existe mais... Quem fazia isso não existe mais... eu mesmo mal vi fazer.... João Marinheiro, João Cabrotia, Leonardo Vieira... Tinha uma velharada ai... Já morreram de velho já... Esse Leonardo morreu com cento e poucos anos... Meu pai mesmo morreu com cem... Cento e sete anos... Nós somos nascidos por ai... nosso umbigo ta por ai...

Arqueólogo3: Por que... $\mathrm{O}$ que faz com o umbigo?

Ancião2: Enterra na terra...

Arqueólogo3: Por que enterra na terra?

Ancião1: Ah, isso não sei... Pro bicho não comer... Formiga... Parteira era a Elisangela ... Cuidava e dava remédio do mato... a criança já tava no remédio pra nascer sadia... Mas só remédio do mato... E não existiam essas doenças que estão aparecendo agora... 
Arqueólogo3: Que doença esta aparecendo agora?

Ancião1: Pressão, hemorróidas e essas outras doenças que eu nunca ouvi falar e que estão aparecendo agora... Meu pai nunca tomou uma injeção... Nunca tomou um comprimido de farmácia... Não existia... Eram difíceis as coisas aqui... Na época da minha bisavó... Ela deixava o Caraguatá na água pra tirar lenha pra fazer linhaça...

Ancião2: O senhor sabe o que é Caraguatá, não é?

Arqueólogo3: Não...

Ancião2: Erva do mato cheio de espinho dos dois lados... torcia ia emendando até ficar comprido. Quatro metros já da uma linha pra pescar uns peixes...

Ancião1: Eles desenhavam pote com trançadinho de Caraguatá.

Arqueólogo3: Só Caraguatá o senhor via?

Ancião1: Só...

Arqueólogo3: Por que outro não servia?

Ancião1: Por que não tinha linha...

Arqueólogo3: E o desenho significava o que?

Ancião1: Era um trabalho de índio... Só índio que compreendia...

Arqueólogo3: Mas vocês são índios não são?!Só quem fez que sabia o que era?

Ancião1: É...

Arqueólogo3 (00:45:00): Além de desenhar com corda de Caraguatá, fazia o que mais?

Ancião1: Linha pra costurar... Dava uma linha igual a essas compradas ai... Linha de náilon...

Arqueólogo3: O que mais que fazia?

Ancião1: Fazia muita coisa... Fazia chapeuzinho... Chapéu igual aque que tenho pendurado, chapéu trançado. Trançado de dez, onze metros e ia costurando..

Arqueólogo3: Vocês têm ainda o chapéu?

Ancião1:Deve ter ai guardado... É só da folha do Carandá..

Arqueólogo3: E a lança, a ponta era de metal?

Ancião1: Quando achava era de metal.

Arqueólogo3: Mas não fazia na época do senhor?

Ancião1: Fazia ....Fazia de metal, fazia de vergão de aço, fazia de cerne de arueira..

Ancião2: Isso ai não quebra, madeira dura... isso que eles tão falando de plantar...

Ancião1: É porque essa madeira não tem mais aqui, não.

Arqueólogo3: O que mais que acabou aqui?

Ancião2: Só isso... Tem o taquaruçu, mas eu acho que é pior que esse ai...

Arqueólogo3: Os Cadiweu faziam pote sem desenho de carandá ou só com carandá que fazia pote?

Ancião1: Fazia pote sem desenho...

Arqueólogo3: Fazia pintado? Pintado com o que? Ancião2:Branco com o próprio barro... Às vezes eles amassavam o barro que ficava bem fininho, ai eles desenhavam nele... Botavam no fogo pra assar...

Como que era o fogo?

Ancião2: Era feito com qualquer madeira... Só de madeira...

Arqueólogo3: E era que tamanho o pote?

Ancião2: Era de todo tipo... Eu mesmo tinha um, mas faz muito tempo...

Arqueólogo3: Mas qual que era o maior do senhor?

Ancião2: O maior era de três latas de água de querosene... Dezoito litros... Tinha dessa grossura aqui... Era pra eu comprar uma que dona ali me ofereceu, a mulher do Elviro, ia comprar dela.

Arqueólogo3: A mulher do seu Erviro?

Ancião2: É o senhor já andou ali perto da igrejinha... $\mathrm{Na}$ frente da igrejinha...

Ancião2: É só perguntar quem faz pote ali... Ele sabe... Eu mandei trazer, eu ia comprar, mas ele não trouxe...

Arqueólogo3: E aqueles torrões de cupim é pra que são?

Ancião1: Isso ai é pra dar pras galinhas...

Arqueólogo3: Qual é o nome dos marcos que tem aqui?

Ancião2: Não sei o que significa... Tem ir lá ver... Arqueólogo3: Além daquele marco tem outro?

Ancião2: Diz que tem, mas eu não sei, não cheguei a ver... Na cerca mesmo que vai pra cá tem um cunhado que é expedicionário que ajudou a desmanchar a cerca... que o dia que entrasse em questão a cerca podia chamar ele que ele que ajudou a desmanchar da divisa pra cá... Divisa com o rio..

Arqueólogo3: Que mais tem de marco?

Ancião2 (00:53:00): De marco que conheci era só isso ai...pedra branca, lazão, .... da placa da estrada ( da entrada da aldeia) pro rio.

Arqueólogo3: E a pedra branca onde que é?

Ancião2: É pra cá perto do Lazão.... onde tem um pé de jacobeiro. Essa ai que ta difícil....

Arqueólogo3: Difícil de que?

Ancião2: Difícil de requerer..

Arqueólogo3: Ah! Área lá (tomada pelo fazendeiro vizinho)...

Ancião2: É. Quem me mostrou isso foi o Tio João, faz vinte e pouco anos que ele morreu .Nós caçávamos ai ele me mostrou. Ai guardei nas idéia e quando o meu filho me informou o que vocês tavam caçando ( pesquisando) contei para ele.

Ancião1: para vocês terem uma idéia de quanto arruinaram a cerca....

Ancião2: Dr. Bonifácio Carvalho... que comprou essa parte ai que falam que é nossa.

Ancião1: Comprou, não. Mediu ai, certo!? foi o "Dr. Bonifácio que mandou." Que era dono da fazenda Engenho, buscou outro que mediu. 
Ancião2: Tem um primo meu, acho que você já viu aquele que está com duas muletas. Eu ia puxando corrente com ele...

Ancião1: Para não perder os rumos dos marcos. $\mathrm{Eu}$ assisti ele puxar corrente, cada metro a corrente... lembro bem como se fosse hoje.

Arqueólogo3: A corrente era para que?

Ancião2: Para medir, a corrente de cinqüenta metro, ia medindo na estaca. Tiraram uma linha que foi direto no marco.

Arqueólogo3: Tem pedra gravada por ai, escrita? Ancião2: nunca vi, nem ouvi falar....

Arqueólogo3; Essa pedra branca não estava escrita?

Ancião2: Não.Era três pedras só.Ali no engenho ( fazenda), na área de campo é 'garrafão'. Ai tinha um cunhado meu, trabalhava com o capataz da fazenda, chamava Mario, mostrava a linha pro Maneco que saia, até na pedra branca. Pedra é branca até no rio.

Arqueólogo3( 00:59:26): E lá no laranjal fazia pote também?

Ancião2: Não, eu passei uma vez, ali caçando. O meu primo me mostrou, era formado, só pé-delaranja. Procurei com ele se tinha morador lá, mas não. Eram os corridos da guerra dos paraguaios com os Cadiweus. Foi ai que apareceu o meu pai, o meu pai era cadiweu a minha mãe Kinikinau, nem existe mais.

Arqueólogo3: Ele conheceu a sua mãe a onde?

Ancião2: Conheceu aqui.

Arqueólogo3: No pirizal?

Ancião2: È, ele era corrido também.

Arqueólogo3: Não nasceu aqui?

Ancião2: Não

Arqueólogo3: Seu Vô também?

Ancião2: Era corrido também, mas ele era jaguncio... veio matando muito paraguaio.

Arqueólogo3 (01:00:07): Mas ele nasceu aqui? Ou em outro lugar?

Ancião2: Outro lugar, ele era homem feito.

Arqueólogo3: Ele era índio também? De onde?

Ancião2: Era índio. De onde que pode ser da nação Kinikinau? Do sul ou do Norte? Só sei que ele apareceu aí.

Arqueólogo3: Não sei. Esse é o seu avô do lado da mãe?! E do lado de pai?

Ancião2: É. Do lado do pai é Kadiwéu.

Arqueólogo3: Ele nasceu a onde?

Ancião2: Ele nasceu lá na aldeia kadiwéu. Ele correu de lá para cá.

Arqueólogo3: Por que ele corre?

Ancião2: Correu porque não queria morrer.

Arqueólogo3: Ah! Porque estava em guerra!?

Ancião2: $\stackrel{E}{E}$

Ancião1: Eles se reuniram aqui e não correram mais. Eram bem armados, eram guerreiros tinham até armas de guerra, mosquetão, carabina 44.

Arqueólogo3: Enterrava com mosquetão?
Ancião1: Não. Chegou um chefe (de posto da FUNAI) e desarmou nós tudo. Aí os fazendeiros queimaram nossas casas aqui, ai cada um arrumou um porrete uma flecha, para correr atraz daqueles que vinham aqui, dos fazendeiros. De certo pagaram o chefe e ele tirou todas as armas.

Arqueólogo3: Como chamava esse chefe de posto?

Ancião2: André Leite.

Arqueólogo3: Ele era índio também?

Ancião2: Não.

Ancião1: Esse posto aí veio muita gente, mas só civilizado (brancos). Agora que entrou um ai, encarregado, que é Índio.

Arqueólogo3: E machado de pedra?

Ancião1: Às vezes se encontra por aí,no nosso tempo a gente usava pra cortar árvore machado de metal. Nós achavamos só machado quebrado.

Arqueólogo3: Em qual parte tinha mais?

Ancião1: Qualquer parte, sempre que nós fazia uma lagoa achava.

Arqueólogo3: De quem que era?

Ancião1: ninguém sabe.

Ancião2: De certo quem morava aqui de primeiro, com aquelas revoltas dos índios, correram, largaram ou mataram. Vieram os Kadiwéu e acamparam aqui.

Ancião1: Agora é patrimônio dos índios. È dos netos, dos bisnetos.

Arqueólogo3: Sempre vem branco aqui?

Ancião2: Só lá no posto ( da FUNAI) quando vem gente aqui é para pescar.

Arqueólogo3: E pra estudar?

Ancião1: Não vem

Ancião2: Só Índio.

Arqueólogo3: Vocês acham que estamos fazendo o que aqui de trabalho? A professora?

Ancião2: Não sei ... Acho que ela está estudando os cacos de pote.

Ancião1: Esse trabalho é muito difícil, pra nóis que não sabe nada não pode declarar.

Arqueólogo3: Ué; saber, vocês sabem sim! Olha quanta coisa vocês me disseram. Sabe bastante coisa sim. Difícil é lembrar né!?

Ancião1 e Ancião2: É

Ancião1: Ela tá fazendo um trabalho muito bom. Vai ver esses novatos que estão formados vem aqui entender, saber melhor. Porque é muito difícil chegar uma pessoa aqui.

Ancião2: É pra fazer esse trabalho nunca vi. Já veio agromensor... um outro branco que veio aqui, procurando índio não deu conta.

Arqueólogo3: E a liderança2 está gostando de trabalhar com os arqueololgo

Ancião2: Ta gostando...

Ancião1: Ela vai saber de muita coisa boa. Muita coisa boa.

Arqueólogo3: O que, por exemplo?

Ancião1: Alguma coisa que nós nunca esperava de saber. 
Arqueólogo3: Saber o que?

Ancião1: Saber o movimento daqui. $\mathrm{O}$ que se passou

Ancião2: O que se passa, o que se movimentou, tem horas que fica do mesmo jeito,

Ancião1: E nós inocente aqui, sem saber de nada. Arqueólogo3: Sabe um pouco sim, sabe que tem o Laranjal, sabe que tem o Pirizal, o Urubeba e a pedra branca.

Ancião1: Aqui dentro da área que nós sabe é isso ai.

Arqueólogo3: E o que tem lá na Toca da Onça, que o senhor estava me contando ontem?

Ancião1: Lá era acampamento desses guerreiro mesmo. Cruzou muito gado aqui, atravessando dali.

Arqueólogo3: Acampamento guerreiro da onde? Os Kadiwéi?

Ancião1: É. Esses índios mesmo que viam escondidos, eles eram poucos e os paraguaios eram muitos, eles matavam de 'atreção'.

Arqueólogo3: O que é matar de 'atreção'?

Ancião1: É matar sem ele vê.

Arqueólogo3: Ah, eles escondiam depois atacavam!?

Ancião1: É. A estrada deles (dos paraguaios) era ali e enquanto eles não apareciam eles ( os kadiwéus) não saiam dali. Ali eles passavam sede e fome, sol e chuva e tava ali. Passava e ficava um pouco.

Arqueólogo3: E onde mais eles ficavam?

Ancião1: Aqui no caminho desse porto, era um porto velho, tinha balsa que ia até embaixo, acamparam no campo aqui na área também, aqui ficavam esperando o adversário, dentro do mato.

Arqueólogo3 (1:15:45): O que aconteceu de mais importante aqui na aldeia?

Ancião2: O mais importante que apareceu aqui, que fez o povoado daqui pra frente, foi a professora e o encarregado ( da FUNAI), professora Sofia.

Arqueólogo3: Qual que foi o primeiro cacique da aldeia?

Ancião2: Foi o Inocêncio, quando eu tinha uns três, quatro anos, saiu um baile violento no dia de Santo Antonio. Nós morávamos ai, nossa mãe nos colocou para dormir, e fechou nós na casa e foi no baile. Clareou o dia procuramos a velharada, mas, não estavam ...tava tudo no baile. Ai, arrombamos a porta e fomos lá, mas quando chegamos lá só tinha gente morta. Foi o capataz da fazenda...mataram o meu cunhado a irmã do meu cunhado, mas o capataz morreu também. Laurindo Buarque era o fazendeiro.

Arqueólogo3: que mais teve de conflito?

(não respondem)

Ancião2: Aqui tinha muita gente, que parou, morou, foram embora. Aqui naquele morro do córrego fundo da fazenda, diz que tem uma pedra, como uma laje. Que esta escrito três letras ' $\mathrm{X}$ ', ali muita gente viu de madrugada galo cantar ali.

Arqueólogo3: E o pé-de-garrafa, já viu?

Ancião2: Nunca vi, já escutei ele assobiar, mas pra cá não existe não, existe pro lado do rio , tem muita morraria feia.

Arqueólogo3: O senhor já subiu no morro?

Ancião2: $\mathrm{O}$ daqui sempre suba, já procurei essa pedra, mas não achei. Isso quando caçava, mas agora não saio mais.

Arqueólogo3:O que tem alto do morro?

Ancião2: Tem, porque vê galo cantando, um colega meu foi de madrugada e escutou e disse que tinha uma trilha de campeiro.

Arqueólogo3: E onde tem cruz por aqui?

Ancião2: Cruz! Tem logo ali, ele foi feito por um tal de senhorzinho que desceu à terra. Com certeza é do céu. ( jesus)

Então essa cruz, foi um cunhado que trouxe, uns dez mil metros na ponta do espírito santo, onde está a ' toca da onça'. Quando estivemos lá , ficamos três noites e três dias rezando. E de lá meu cunhado falava que ia atravessar o rio, mas não falava o trajeto. Isso que fiquei admirado e outro que admirei é que ali o rio é poço, a água fica parada, ai ele passou na frente com a cruz no ombro.

Arqueólogo3: Os Kadiwéus dançavam?

Ancião2: Dançava de noite, a semana toda, matava um boi pra festa.

Ancião1: Quando minha tia curava fazendeiro a gente ganhava uma vaca.

Arqueólogo3: Ela era purungueira? Ela está viva?

Ancião1: É. Não já faz muito anos.

Arqueólogo3: Onde tem purungueiro agora?

Ancião2: Só na Cachoeirinha, ali tem um que cura e mata.

Arqueólogo3: Já foram lá?

Ancião2: Não, nos fomos a passeio, quando éramos mais novos, uns quarenta anos.

Arqueólogo3: E dança de Índio fazia?

Ancião2: Fazia, e faz até hoje, como o bate-pau. Vinte e dois anos pra trás veio um índio xavante, mas não teve vontade nenhuma de dançar, mas esses daqui dançam bem. Outra dança de índio nunca vi não. 
Anexo 5.

\title{
I SEMINÁRIO INTERNACIONAL DE GESTÃO DO PATRIMÔNIO ARQUEOLÓGICO PAN-AMAZÔNICO
}

\author{
MANAUS, 5 a 9 Novembro/ 2007 \\ SESSÃO TEMÁTICA: PRESERVAÇÃO DO PATRIMÔNIO ARQUEOLÓGICO \\ EM TERRAS INDÍGENAS
}

\section{Moção de encaminhamento}

Esta moção visa sintetizar os principais pontos de reflexão abordados durante a presente Sessão Temática. Para tanto, o texto é composto por dois blocos, a saber:

> Pontos sensíveis, diretrizes e recomendações, que organiza os principais tópicos de discussão e indica questões sensíveis e recomendações a serem consideradas sobre o assunto;

$>\underline{\text { Acões, }}$ que indica ações a serem desenvolvidas, visando o detalhamento e continuidade das reflexões aqui levantadas para alcance de resultados mais abrangentes nos aspectos estratégicos e operacionais do tema.

\section{PONTOS SENSÍVEIS, DIRETRIZES E RECOMENDAÇÕES}

- Conceito de "terra indígena": no presente trabalho considera-se como terra indígena tanto aquelas terras administrativamente demarcadas pelo governo brasileiro (Tls), aquelas de alguma forma reconhecidas e assumidas pelos outros paises da América do Sul, como as áreas consideradas tradicionais pelas populações indígenas, demarcadas ou não, em especial seus locais de significância simbólica/ sagrada/ cultural. Portanto, as diretrizes técnicas, éticas e operacionais relacionadas ao longo da presente Moção devem ser igualmente aplicadas em todas as 
situações acima mencionadas, que passam a ser designadas simplesmente como "terras indígenas tradicionais".

- O desenvolvimento de Programas Arqueológicos em terras indígenas tradicionais necessita se dar dentro da perspectiva da Arqueologia Colaborativa, com base na ação compartilhada e no envolvimento pluricultural, não assimétrico ou hierárquico, envolvendo equipes formadas por pesquisadores e por representantes indígenas, que serão coresponsáveis pelo Programa como um todo, e abrangendo o conjunto de suas etapas.

- As comunidades indígenas envolvidas devem ser os principais beneficiários do desenvolvimento e resultados dos Programas Arqueológicos.

- Os Programas devem garantir a apropriação, pelas comunidades indígenas, do conjunto de dados e resultados obtidos, incluindo o registro do conhecimento e publicações especificamente voltados para elas. Devem, ainda, promover uma análise conjunta, pela equipe de pesquisadores, comunidades indígenas e IPHAN, sobre a destinação final do acervo arqueológico que venha a ser gerado.

- O Programa Arqueológico deve abranger o conjunto do patrimônio cultural, como é entendido e percebido pelas comunidades indígenas, englobando tanto os vestígios arqueológicos em si, quanto bens e/ou vestígios históricos, culturais e paisagísticos, materiais e imateriais, incluindo perspectivas alternativas de discurso e/ou abordagem. No caso do patrimônio paisagístico, o Programa deverá considerar áreas de significância cultural, simbólica e sagrada das comunidades, não necessariamente abrangendo vestígios materiais de sua ocupação.

- Possíveis análises patrimoniais de valoração realizadas em terras indígenas tradicionais (e em especial aquelas voltadas ao licenciamento ambiental de obras de engenharia) devem ser realizadas de maneira 
compartilhada, participativa e colaborativa junto às comunidades indígenas envolvidas, incluindo, de forma não assimétrica ou hierárquica, a identificação, valoração e análise de significância do patrimônio a partir da perspectiva indígena. O mesmo se aplica na indicação de medidas mitigadoras e/ou compensatórias incluídas nos processos de licenciamento ambiental.

- Estudos de diagnóstico arqueológico realizados na bacia amazônica devem incluir nos levantamentos documentais etno-históricos regionais (já exigidos pela Portaria IPHAN 230/02) uma análise específica da possível presença, na área de impacto do empreendimento, de locais e/ou paisagens de significado simbólico/ sagrado para sociedades indígenas que ali se desenvolveram, mesmo que atualmente não mais habitem a área.

- O desenvolvimento de Programas Arqueológicos em terras indígenas tradicionais deve prescindir de autorização específica das comunidades no que se refere ao seu escopo, objetivos, métodos de realização e formas de apresentação dos resultados. No caso do Brasil, recomenda-se que o IPHAN exija este documento de apoio institucional das comunidades indígenas envolvidas, complementarmente ao documento de apoio institucional já exigido nos processos de solicitação de Portaria de Pesquisa, conforme definido pela Portaria 07/88.

- Os Programas Arqueológicos em terras indígenas tradicionais devem incluir a realização de pesquisas em sítios de interesse indígena, além daqueles definidos através da perspectiva científica.

- A realização de qualquer intervenção no patrimônio arqueológico, histórico, cultural e paisagístico presente em terras indígenas tradicionais deve contar com o consentimento das comunidades envolvidas. Inclui-se aqui toda atividade que abranja coletas de material e cortes de terreno, como abertura de sondagens, poços-teste e áreas de escavação. 
- Os Programas Arqueológicos em terras indígenas tradicionais devem incluir a capacitação de técnicos indígenas para atividades voltadas à Arqueologia, Educação Patrimonial, Museologia e Conservação, bem como garantir a maior participação possível de indígenas em todas as fases da pesquisa.

- A elaboração de Programas de Gestão, Manejo, Monitoramento, Preservação, e outros, deve incorporar a perspectiva indígena, na busca de uma condução compartilhada e colaborativa entre as diferentes abordagens envolvidas (abordagem científica, abordagem legal, abordagem indígena).

○ Esta Moção recomenda, por fim, a realização de gestões, em diversas instâncias, para que os sítios arqueológicos e/ou paisagísticos de significado mítico e/ou sagrado para as populações indígenas sejam poupados de empreendimentos causadores de impactos ambientais, que não devem incidir sobre eles. No Brasil tal medida poderá ser buscada por meio de Resolução CONAMA, Portaria do IPHAN, Leis, Decretos ou, ainda, de outras formas de controle sócio-ambiental. Em outros países da América do Sul deverão ser desenvolvidas propostas no âmbito de seus próprios instrumentos de controle sócio-ambiental. 


\section{AÇÕES}

Considerando os pontos sensíveis sobre os temas levantados pela presente Sessão, são recomendadas as seguintes ações:

1) Criação de um Grupo de Trabalho para detalhamento das reflexões aqui iniciadas e acréscimo de outras que se mostrarem pertinentes, com objetivo último de elaborar uma Agenda para Pesquisa e Preservação do Patrimônio Arqueológico, Histórico, Cultural e Paisagístico em Terras Indígenas Tradicionais. Esta Agenda deverá indicar diretrizes técnicas, éticas e operacionais para trabalhos de pesquisa patrimonial a serem desenvolvidos em terras indígenas, abrangendo tanto as terras indígenas administrativamente demarcadas pelo governo brasileiro (TIs), e aquela reconhecidas por cada país amazônico, como aquelas não demarcadas,mas reconhecidas pelas próprias comunidades indígenas como locais ou paisagens de especial significado simbólico/ cultural. A diretriz deste GT deverá estar voltada ao desenvolvimento de uma Arqueologia Colaborativa, nos termos indicados pela presente Sessão. O GT deverá ser composto por representantes indígenas e não indígenas, visando abranger a diversidade de perspectivas necessárias.

2) Criação de Grupos de Trabalho em cada país amazônico, com finalidade de organizar um mapeamento e cadastro de sítios e/ou paisagens de especial significado simbólico/ sagrado/ cultural para as comunidades indígenas da Amazônia. O resultado deste trabalho deverá, entre outros, subsidiar a realização e análise de estudos de diagnóstico arqueológico de empreendimentos e avaliações de impacto junto a processos de licenciamento ambiental e outros, voltados à implantação de obras desenvolvimentistas.

3) Criação de Portaria IPHAN no Brasil, e de outros instrumentos normativos em cada país amazônico, objetivando normatizar a realização de pesquisas patrimoniais em terras indígenas tradicionais, a partir das especificidades técnicas, éticas e operacionais que Ihe são intrínsecas. 
Composição da Sessão Temática "Preservação do Patrimônio Arqueológico em Terras Indígenas"

Maria Clara Migliacio (Coordenadora)

Erika M. Robrahn-González (Relatora)

Fabíola Andrea Silva

Bonifácio José Baniwa

Afukaká Kuikuro

Mutuá Mehinaku

Michael J. Heckemberger

Esta moção soma, ainda, as contribuições oferecidas pelos diferentes participantes do Seminário que contribuíram durante o debate ocorrido ao final das apresentações. 